\title{
The Chemistry of Group 8 Metal Complexes with Phosphinous Acids and Related P-OH Ligands
}

\author{
Javier Francos, ${ }^{\dagger}$ David Elorriaga, ${ }^{\dagger}$ Pascale Crochet, Victorio Cadierno* \\ Laboratorio de Compuestos Organometálicos y Catálisis (Unidad Asociada al CSIC), \\ Centro de Innovación en Química Avanzada (ORFEO-CINQA), Departamento de \\ Química Orgánica e Inorgánica, IUQOEM, Facultad de Química, Universidad de \\ Oviedo, Julián Clavería 8, E-33006 Oviedo, Spain.
}

Dedicated to Professor Armando J. L. Pombeiro for his outstanding achievements in Coordination Chemistry and Catalysis

\section{Contents}

\begin{abstract}
\end{abstract}
1. Introduction

2. Electronic and steric aspects of phosphinous acids

3. Procedures for the preparation of metal complexes with $\mathrm{P}-\mathrm{OH}$ ligands

4. Synthesis and reactivity of iron complexes

5. Synthesis and reactivity of ruthenium complexes

6. Synthesis and reactivity of osmium complexes

7. Applications and involvement in catalysis

7.1. Nitrile hydration reactions

7.2. C-H bond arylation processes

7.3. Hydrogenation reactions

7.4. Other catalytic transformations

8. Conclusions and outlook

Acknowledgements

References

\footnotetext{
$\dagger$ Both authors contributed equally to this manuscript

* Corresponding author. Tel.: +34-985-103-453; fax: +34-985-103-446

E-mail address: vcm@uniovi.es
} 


\begin{abstract}
Despite their inherent instability, phosphinous acids $\mathrm{PR}_{2} \mathrm{OH}$ have emerged in recent years as a useful class of $P$-donor ligands for homogeneous catalysis. The present review article reports on the chemistry of Group 8 metal complexes containing such ligands and related P-OH species. Synthetic methodologies, reactivity studies, as well as the involvement of these compounds in a series of catalytic transformations, are presented. Remarkably, the non-innocent role played by the $\mathrm{PR}_{2} \mathrm{OH}$ ligands in the catalytic hydration of nitriles and $\mathrm{C}-\mathrm{H}$ bond arylation processes has been revealed, evidencing their cooperation with the metal (ruthenium in most of the cases) in the activation of the substrates.
\end{abstract}

Keywords: $\mathrm{P}-\mathrm{OH}$ ligands; Phosphinous acid ligands; Iron complexes; Ruthenium complexes; Osmium complexes; Homogeneous catalysis.

\title{
1. Introduction
}

$P$-donor ligands are ubiquitous in coordination and organometallic chemistry, as well as in the field of homogeneous catalysis [1]. The main attraction of these ligands is that their steric and electronic properties can be easily modified by varying the pendant groups attached to the phosphorus atom [2]. In this regard, alkyl, aryl, alkoxy or amino groups have been widely employed to tune the properties of the metal complexes to which the $\mathrm{PR}_{3}$ units are attached. Much less frequent to find in the literature are examples in which one (or more) of the substituents on the phosphorus atom is a 
hydroxyl group. This is due to the instability of these species in the free state since, once the $\mathrm{P}-\mathrm{OH}$ bond is generated, a spontaneous rearrangement into the thermodynamically favored $\mathrm{P}(=\mathrm{O}) \mathrm{H}$ tautomer takes place. The prototypical example is that of phosphinous acids $\mathrm{PR}_{2} \mathrm{OH}(\mathrm{R}=$ alkyl or aryl group), which exist in a tautomeric equilibrium with the corresponding secondary phosphine oxides (SPOs) $\mathrm{R}_{2} \mathrm{P}(=\mathrm{O}) \mathrm{H}$, being such equilibrium almost completely shifted towards the oxide form in most of the cases [3]. Only when the $\mathrm{R}$ substituents are strong electron-withdrawing groups, the $\mathrm{P}(\mathrm{III})$ tautomer is stable enough to be isolated [4]. Thus, typical examples of stable phosphinous acids are the perfluoroalkyl derivatives $\mathrm{P}\left(\mathrm{CF}_{3}\right)_{2} \mathrm{OH}[4 \mathrm{~b}]$ and $\mathrm{P}\left(\mathrm{C}_{2} \mathrm{~F}_{5}\right)_{2} \mathrm{OH}$ [4g], which were found to be 14.0 and $11.7 \mathrm{~kJ} / \mathrm{mol}$, respectively, more stable than their SPO counterparts, i.e. $\left(\mathrm{CF}_{3}\right)_{2} \mathrm{P}(=\mathrm{O}) \mathrm{H}$ and $\left(\mathrm{C}_{2} \mathrm{~F}_{5}\right)_{2} \mathrm{P}(=\mathrm{O}) \mathrm{H}$. In marked contrast, when classical alkyl or aryl groups are bound to the phosphorus atom, only the pentavalent species are observed in solution or the solid state. In this context, Börner and coworkers calculated the differences in free enthalpy between the SPOs $\mathrm{R}_{2} \mathrm{P}(=\mathrm{O}) \mathrm{H}(\mathrm{R}=$ $\left.{ }^{t} \mathrm{Bu}, 4-\mathrm{C}_{6} \mathrm{H}_{4} \mathrm{Me}, \mathrm{Ph}, 4-\mathrm{C}_{6} \mathrm{H}_{4} \mathrm{~F}\right)$ and the corresponding phosphinous acid tautomers, obtaining values of $-31.2,-16.5,-12.6$ and $-10.9 \mathrm{~kJ} / \mathrm{mol}$, respectively [4h]. The group of Börner also reported intermediate situations in the case of compounds $\left(\mathrm{C}_{6} \mathrm{~F}_{5}\right)_{2} \mathrm{P}(=\mathrm{O}) \mathrm{H}$, $\left(\mathrm{C}_{5} \mathrm{~F}_{5} \mathrm{~N}\right)_{2} \mathrm{P}(=\mathrm{O}) \mathrm{H}$ and $\left\{2,4-\mathrm{C}_{6} \mathrm{H}_{3}\left(\mathrm{CF}_{3}\right)_{2}\right\}_{2} \mathrm{P}(=\mathrm{O}) \mathrm{H}$, which predominate as such in solid state, whereas in solution they establish a solvent dependent equilibrium with the phosphinous acid tautomers [4i]. Several theoretical studies on this tautomerism have been performed [4d-f,j], suggesting the bimolecular mechanism depicted in Eq. 1 as the most likely.

2

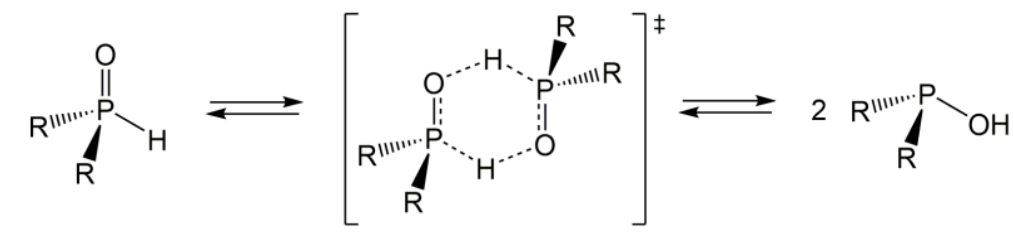


On the other hand, it is now well established that in the presence of a transition metal the SPO/phosphinous acid equilibrium can be totally inverted by $P$-coordination of the phosphinous acid form to the metal. This was evidenced for the first time in 1968 by Chatt and Heaton with the preparation of the $\operatorname{Pt}(\mathrm{II})$ complex cis$\left[\mathrm{PtCl}_{2}\left(\mathrm{PPh}_{2} \mathrm{OH}\right)\left(\mathrm{PEt}_{3}\right)\right]$ by treatment of the dimeric species $\left[\left\{\mathrm{PtCl}(\mu-\mathrm{Cl})\left(\mathrm{PEt}_{3}\right)\right\}_{2}\right]$ with an excess of $\mathrm{Ph}_{2} \mathrm{P}(=\mathrm{O}) \mathrm{H}$ [5]. Since then, a wide array of metal complexes with phosphinous acid ligands have been obtained following the same strategy [6]. More importantly, this type of complexes (pre-formed or generated in situ by combining a metal precursor with a SPO pre-ligand) has emerged in recent years as a relevant class of catalysts for different organic transformations, including cycloaddition ( $\mathrm{Pd}$ and $\mathrm{Pt}$ ), cross-coupling ( $\mathrm{Pd}$ and $\mathrm{Ni})$, hydrogenation ( $\mathrm{Rh}$ and $\mathrm{Ir}$ ) and hydroformylation $(\mathrm{Rh})$ processes, to name a few [7].

In this review article, the chemistry of Group 8 metal complexes featuring phosphinous acids and related $\mathrm{P}-\mathrm{OH}$ ligands, i.e. species of type $\mathrm{P}(\mathrm{OR})_{2} \mathrm{OH}, \mathrm{PR}(\mathrm{OH})_{2}$, $\mathrm{P}(\mathrm{OR})(\mathrm{OH})_{2}, \mathrm{HP}(\mathrm{OH})_{2}$ and $\mathrm{P}(\mathrm{OH})_{3}$ among others, is discussed. Their synthesis, reactivity and involvement in homogeneous catalysis are presented. Concerning the catalytic part, both pre-formed and in situ generated complexes are covered, highlighting the non-innocent role played by the nucleophilic, $\mathrm{pH}$ responsive and $\mathrm{H}$ bond donor $\mathrm{OH}$ group in most of the reactions. As the reader will see, the demonstrated ability of these ligands to cooperate with the metal in the activation of the substrates makes them ideal candidates for the future development of new bifunctional catalysts [8].

\section{Electronic and steric aspects of phosphinous acids}


Despite the growing interest in the use of phosphinous acids in coordination chemistry and catalysis [6,7], little attention has been paid to date to the study of their electronic and steric properties. In this regard, the work carried out by Martin, Buono and co-workers in the determination of the Tolman's electronic parameter (TEP) of different carbon- and heteroatom-substituted $\mathrm{P}-\mathrm{OH}$ ligands merits to be highlighted [9a]. Thus, through Density Functional Theory (DFT) calculations, they determined the frequency of the A1 carbonyl stretching mode of the corresponding $\left[\mathrm{LNi}(\mathrm{CO})_{3}\right]$ complexes, and subsequently extrapolated the TEP values of the ligands applying the empirical linear correlation TEP $=\bar{v}_{\mathrm{CO}}($ theoretical $) \times 0.9540\left(r^{2}=0.995\right)$ established by Gusev [9b] (see entries 1-10 in Table 1). The TEP values obtained indicated that, in general terms, the phosphinous acid ligands $\mathrm{PR}_{2} \mathrm{OH}$ are less donating than the corresponding trisubstituted phosphines $\mathrm{PR}_{3} \quad$ (or phosphites $\mathrm{P}(\mathrm{OR})_{3}$ and aminophosphines $\mathrm{P}\left(\mathrm{NR}_{2}\right)_{3}$ in the case of the heteroatom-substituted $\mathrm{P}-\mathrm{OH}$ ligands studied). In addition, the authors observed no systematic effect of the $\mathrm{OH}$ group on TEPs. For instance, TEP values for $\mathrm{PMe}_{2} \mathrm{OH}$ and $\mathrm{PPh}_{2} \mathrm{OH}$ were found to be identical (entries 1 and 2), when it is well established that $\mathrm{PMe}_{3}$ is a stronger donating ligand in comparison with $\mathrm{PPh}_{3}$ or $\mathrm{PPh}_{2} \mathrm{Me}$. In the same study, the TEPs of various anionic phosphinito ligands were also determined (entries 11-19 in Table 1). The low TEP values obtained (from 2006 to $2028 \mathrm{~cm}^{-1}$ ) indicated the highly electron donating character of these anionic ligands, superior for example to that shown by $N$-heterocyclic carbenes. The marked changes in the donor properties of the neutral phosphinous acids $\mathrm{PR}_{2} \mathrm{OH}$ vs the anionic phosphinites $\mathrm{PR}_{2} \mathrm{O}^{-}$is a relevant aspect that can be behind the exceptional behavior of these ligands in some catalytic transformations, in which deprotonation of the phosphinous acids can take place in the course of the reaction. 
Table 1. TEP values for different phosphinous acids and their phosphinito anions. ${ }^{a}$

\begin{tabular}{|c|c|c|c|}
\hline Entry & Ligand (L) & $\bar{v}_{\mathrm{CO}}$ for $\left[\mathrm{LNi}(\mathrm{CO})_{3}\right]^{b}$ & Extrapolated $\mathrm{TEP}^{c}$ \\
\hline 1 & $\mathrm{PMe}_{2} \mathrm{OH}$ & $2172.0 \mathrm{~cm}^{-1}$ & $2072 \mathrm{~cm}^{-1}$ \\
\hline 2 & $\mathrm{PPh}_{2} \mathrm{OH}$ & $2172.3 \mathrm{~cm}^{-1}$ & $2072 \mathrm{~cm}^{-1}$ \\
\hline 3 & $\mathrm{P}^{t} \mathrm{BuPhOH}$ & $2169.8 \mathrm{~cm}^{-1}$ & $2070 \mathrm{~cm}^{-1}$ \\
\hline 4 & $\mathrm{P}^{t} \mathrm{Bu}_{2} \mathrm{OH}$ & $2164.4 \mathrm{~cm}^{-1}$ & $2064 \mathrm{~cm}^{-1}$ \\
\hline 5 & $\mathrm{PCy}_{2} \mathrm{OH}$ & $2165.6 \mathrm{~cm}^{-1}$ & $2066 \mathrm{~cm}^{-1}$ \\
\hline 6 & $\mathrm{PAd}_{2} \mathrm{OH}^{d}$ & $2160.9 \mathrm{~cm}^{-1}$ & $2061 \mathrm{~cm}^{-1}$ \\
\hline 7 & $\mathrm{P}\left(\mathrm{CF}_{3}\right)_{2} \mathrm{OH}$ & $2201.4 \mathrm{~cm}^{-1}$ & $2100 \mathrm{~cm}^{-1}$ \\
\hline 8 & $\mathrm{P}(\mathrm{OMe})_{2} \mathrm{OH}$ & $2180.4 \mathrm{~cm}^{-1}$ & $2080 \mathrm{~cm}^{-1}$ \\
\hline 9 & $\mathrm{OH}_{\mathrm{H}}$ & $2188.0 \mathrm{~cm}^{-1}$ & $2087 \mathrm{~cm}^{-1}$ \\
\hline 10 & & $2173.1 \mathrm{~cm}^{-1}$ & $2073 \mathrm{~cm}^{-1}$ \\
\hline 11 & $\mathrm{PMe}_{2} \mathrm{O}^{-}$ & $2103.0 \mathrm{~cm}^{-1}$ & $2006 \mathrm{~cm}^{-1}$ \\
\hline 12 & $\mathrm{PPh}_{2} \mathrm{O}^{-}$ & $2119.4 \mathrm{~cm}^{-1}$ & $2021 \mathrm{~cm}^{-1}$ \\
\hline 13 & $\mathrm{P}^{t} \mathrm{BuPhO}^{-}$ & $2114.2 \mathrm{~cm}^{-1}$ & $2017 \mathrm{~cm}^{-1}$ \\
\hline 14 & $\mathrm{P}^{t} \mathrm{Bu}_{2} \mathrm{O}^{-}$ & $2106.8 \mathrm{~cm}^{-1}$ & $2010 \mathrm{~cm}^{-1}$ \\
\hline 15 & $\mathrm{PCy}_{2} \mathrm{O}^{-}$ & $2105.4 \mathrm{~cm}^{-1}$ & $2008 \mathrm{~cm}^{-1}$ \\
\hline 16 & $\mathrm{PAd}_{2} \mathrm{O}^{-}$ & $2106.4 \mathrm{~cm}^{-1}$ & $2009 \mathrm{~cm}^{-1}$ \\
\hline 17 & $\mathrm{P}\left(\mathrm{CF}_{3}\right)_{2} \mathrm{O}^{-}$ & $2143.1 \mathrm{~cm}^{-1}$ & $2044 \mathrm{~cm}^{-1}$ \\
\hline 18 & $\mathrm{O}^{-}$ & $2126.4 \mathrm{~cm}^{-1}$ & $2028 \mathrm{~cm}^{-1}$ \\
\hline 19 & & $2109.7 \mathrm{~cm}^{-1}$ & $2013 \mathrm{~cm}^{-1}$ \\
\hline & $\mathrm{Me}$ & & \\
\hline
\end{tabular}

${ }^{a}$ Data taken from ref. [9a]. ${ }^{b}$ Obtained from DFT calculations employing the MPW1PW91 functional. ${ }^{c}$ Calculated from the empirical correlation TEP $=\bar{v}_{\mathrm{CO}}$ (theoretical) $\mathrm{x} 0.9540$ according to ref. [9b]. ${ }^{d} \mathrm{Ad}=1$-adamantyl. 
Concerning the steric properties of these ligands, Clavier and co-workers [10] quantified through DFT calculations the percent buried volume $\left(\% \mathrm{~V}_{\text {bur }}\right)$ [11] of different phosphinous acids coordinated to the $\mathrm{Ru}(\mathrm{II})$ fragment $\left[\mathrm{RuCl}_{2}\left(\eta^{6}-p\right.\right.$-cymene $\left.)\right]$. As shown in Table 2, values span from 21.9 to $24.6 \%$ (entries 1-8). The $\% \mathrm{~V}_{\text {bur }}$ of $\mathrm{PPh}_{2} \mathrm{OH}$ was also compared to that of related diphenylphosphines $\mathrm{PPh}_{2} \mathrm{R}$ and $\mathrm{P}(\mathrm{OPh})_{3}$. As expected, $\mathrm{PPh}_{2} \mathrm{OH}$ is more sterically demanding than $\mathrm{PPh}_{2} \mathrm{H}$ (entry 2 vs 10) but less than other $\mathrm{PPh}_{2} \mathrm{R}\left(\mathrm{R}=\mathrm{CH}_{2} \mathrm{OH},{ }^{\mathrm{n}} \mathrm{Bu}\right.$ and $\left.\mathrm{Ph}\right)$ ligands or $\mathrm{P}(\mathrm{OPh})_{3}$ (entry 2 vs 11-14).

Table 2. Percent buried volume of various ligands in $\left[\mathrm{RuCl}_{2}\left(\eta^{6}-p\right.\right.$-cymene $\left.)(\mathrm{L})\right]$ complexes. $^{a}$

\begin{tabular}{cll}
\hline Entry & Ligand $(\mathrm{L})$ & $\% V_{\text {bur }}(\mathrm{L})$ \\
\hline 1 & $\mathrm{PMe}_{2} \mathrm{OH}$ & 21.9 \\
2 & $\mathrm{PPh}_{2} \mathrm{OH}$ & 24.6 \\
3 & $\mathrm{P}\left(4-\mathrm{C}_{6} \mathrm{H}_{4} \mathrm{~F}\right)_{2} \mathrm{OH}$ & 24.6 \\
4 & $\mathrm{PCy}{ }_{2} \mathrm{OH}$ & 24.4 \\
5 & $\mathrm{PMePhOH}$ & 22.7 \\
6 & $\mathrm{P}^{\mathrm{n}} \mathrm{BuPhOH}$ & 22.7 \\
7 & $\mathrm{PCyPhOH}$ & 24.1 \\
8 & $\mathrm{P}^{\mathrm{t}} \mathrm{BuPhOH}$ & 24.4 \\
10 & $\mathrm{PPh}_{2} \mathrm{H}$ & 23.2 \\
11 & $\mathrm{PPh}_{2} \mathrm{CH} H_{2} \mathrm{OH}$ & 25.1 \\
12 & $\mathrm{PPh}_{2}{ }^{\mathrm{B}}$ & 25.6 \\
13 & $\mathrm{PPh}_{3}$ & 26.8 \\
14 & $\mathrm{P}\left(\mathrm{OPh}_{3}\right.$ & 24.7 \\
\hline${ }^{a}$ Data taken from ref. $[10]$. & & \\
\hline
\end{tabular}

\section{Procedures for the preparation of metal complexes with P-OH ligands}


As we have commented above, the most common method to obtain metal complexes with coordinated phosphinous acid ligands is by tautomerization of the corresponding secondary phosphine oxide (Eq. 2). Such a tautomerization process is quite general and can be applied to other pentavalent species such as phosphites $(\mathrm{RO})_{2} \mathrm{P}(=\mathrm{O}) \mathrm{H}$, diaminophosphine oxides $\left(\mathrm{R}_{2} \mathrm{~N}\right)_{2} \mathrm{P}(=\mathrm{O}) \mathrm{H}$, phosphinic acids $\mathrm{RP}(=\mathrm{O})(\mathrm{OH}) \mathrm{H}$, hypophosphorous acid $\mathrm{H}_{3} \mathrm{PO}_{2}$, phosphorous acid $\mathrm{H}_{3} \mathrm{PO}_{3}$, phosphine oxide $\mathrm{H}_{3} \mathrm{P}=\mathrm{O}$, etc., allowing in the presence of a metal the stabilization of the corresponding thermodynamically non-favored trivalent $\mathrm{P}-\mathrm{OH}$ tautomers.

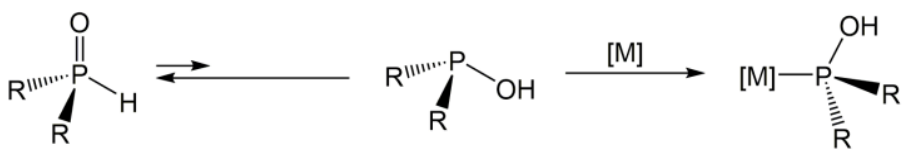

An alternative procedure for the generation of metal complexes with $\mathrm{P}-\mathrm{OH}$ ligands is by hydrolysis of the P-X bond of coordinated phosphites, aminophosphines or halophosphines (Eq. 3). As we will comment in the following sections, such hydrolytic P-heteroatom bond cleavage reactions have also been reported for metal-coordinated white phosphorus $\left(\mathrm{P}_{4}\right)$ and phosphorous sesquisulfide $\left(\mathrm{P}_{4} \mathrm{~S}_{3}\right)$.

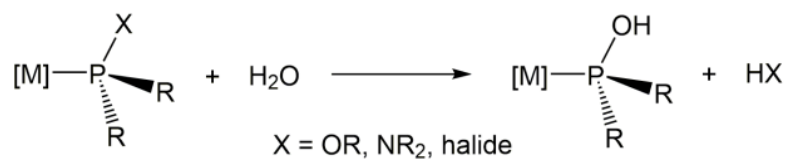

Less common, but yet well documented, is the hydrolysis of the P-C bonds in coordinated phosphines (Eq. 4).

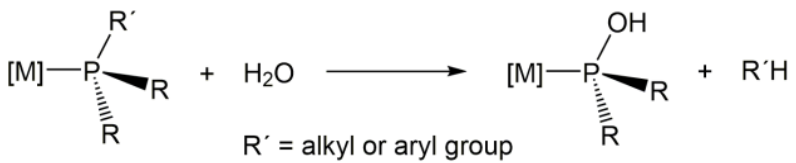


The protonation of phosphinate and phosphonate complexes has also been extensively employed to generate metal complexes with coordinated P-OH ligands (Eq. $5)$.

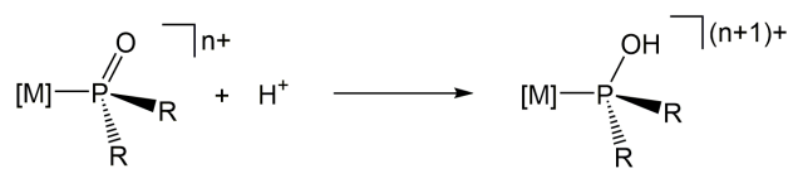

Examples of all these transformations within the chemistry of iron, ruthenium and osmium will be given along the present review article. Less general reactions involving, for example, the hydrolysis of phosphinidene complexes or the oxidation of metalcoordinated secondary phosphines $\mathrm{PHR}_{2}$ will also be commented.

\section{Synthesis and reactivity of iron complexes}

To the best of our knowledge, the first mention to an iron compound with a coordinated P-OH ligand was made by Verkade and co-workers in 1967 while studying the reactivity of the polycyclic phosphite 2,8,9-trioxa-1-phosphaadamantane with hydrated metal salts [12]. Apparently, in the presence of $\mathrm{Fe}\left(\mathrm{ClO}_{4}\right)_{2} \cdot \mathrm{nH}_{2} \mathrm{O}$, hydrolysis of one of the $\mathrm{P}-\mathrm{O}$ bonds of this phosphite ligand takes place leading to a poorly characterized complex formulated as $\left[\mathrm{Fe}\left(\mathrm{H}_{2} \mathrm{O}\right)_{2}\left\{\mathrm{P}(\mathrm{OR})_{2} \mathrm{OH}\right\}_{4}\right]\left[\mathrm{ClO}_{4}\right]_{2}$. Early examples fully characterized were the half-sandwich phosphinous acid iron(II) derivatives $\left[\mathrm{FeCp}(\mathrm{CO})_{2}(\mathrm{PPhROH})\right][\mathrm{Br}]\left(\mathrm{R}=\mathrm{Ph},{ }^{\mathrm{t}} \mathrm{Bu}\right)(3)$. As shown in Scheme 1, they were obtained from the corresponding chlorophosphine complexes $\left[\mathrm{FeCp}(\mathrm{CO})_{2}(\mathrm{PPhRCl})\right][\mathrm{X}]$ $\left(\mathrm{R}=\mathrm{Ph}, \mathrm{X}^{-}=\mathrm{BF}_{4}^{-} ; \mathrm{R}={ }^{\mathrm{t}} \mathrm{Bu}, \mathrm{X}^{-}=\mathrm{PF}_{6}{ }^{-}\right)(\mathbf{1})$ through a two-step sequence involving the initial hydrolysis of $\mathbf{1}$ in basic media, followed by protonation of the resulting dinuclear hydrogen-bridged species $\left[\left\{\mathrm{FeCp}(\mathrm{CO})_{2}(\mathrm{PPhRO})\right\}_{2} \mathrm{H}\right][\mathrm{X}]\left(\mathrm{R}=\mathrm{Ph}, \mathrm{X}^{-}=\mathrm{BF}_{4}^{-} ; \mathrm{R}={ }^{\mathrm{t}} \mathrm{Bu}\right.$, $\left.\mathrm{X}^{-}=\mathrm{PF}_{6}^{-}\right)(2)$ with $\mathrm{HBr}_{(\mathrm{g})}$ [13]. The structure of one of the dinuclear intermediates $2(\mathrm{R}$ 
$\left.={ }^{\mathrm{t}} \mathrm{Bu}\right)$ could be unambiguously established by single-crystal X-ray diffraction. Nonetheless, titration data for aqueous acetone solutions of $\mathbf{3}$ gave no evidence for the intermediacy of the dinuclear species 2 after addition of 0.5 equivalents of base, suggesting that compounds $\mathbf{2}$ are substantially dissociated into the corresponding mononuclear species $\left[\mathrm{FeCp}(\mathrm{CO})_{2}(\mathrm{PPhROH})\right]^{+}$and $\left[\mathrm{FeCp}(\mathrm{CO})_{2}\{\mathrm{P}(=\mathrm{O}) \mathrm{PhR}\}\right]$ in solution, the latter being selectively formed upon addition of 1 equivalent of base.
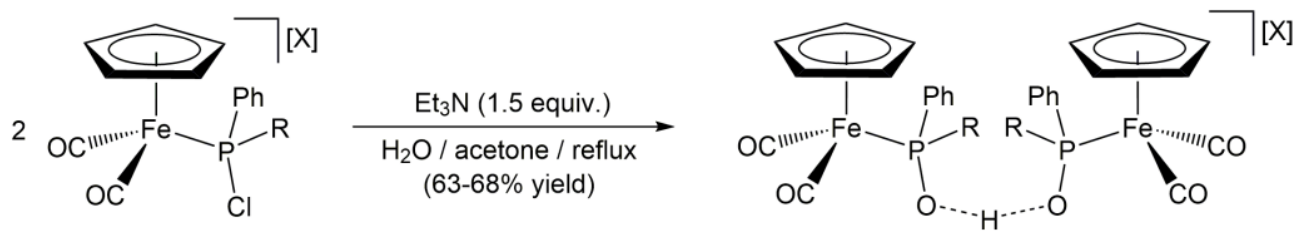

$$
\begin{aligned}
& R=P h, X^{-}=\mathrm{BF}_{4}^{-} \\
& R={ }^{\mathrm{t}} \mathrm{Bu}, \mathrm{X}^{-}=\mathrm{PF}_{6}^{-}
\end{aligned}
$$
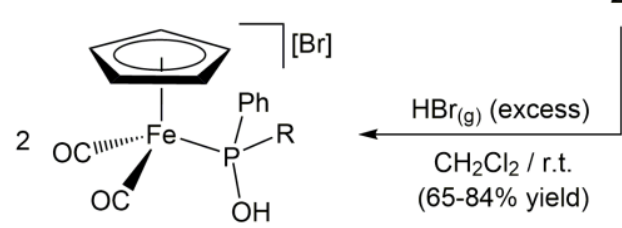

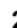

Scheme 1. Synthesis of the cationic phosphinous acid-iron(II) complexes 3 .

The neutral cyclopentadienyl-iron(II) complex $\left[\mathrm{FeCp}\{\mathrm{C}(\mathrm{O}) \mathrm{Me}\}(\mathrm{CO})\left(\mathrm{PPh}_{2} \mathrm{OH}\right)\right]$ (5), containing diphenylphosphinous acid as ligand, is also known (Scheme 2) [14]. It was obtained by acidic hydrolysis of the amino-phosphine ligand in the optically active acyl-Fe(II) derivative 4 upon treatment with aqueous $\mathrm{HBF}_{4}$. Remarkably, the reaction proceeded with complete retention of the configuration at the stereogenic iron center. In addition, given the structural resemblance of 5 to the enol form of a $\beta$-dicarbonyl compound, the authors could prepare the dinuclear species 6, whose structure was unambiguously established by X-ray diffraction, through the treatment of a toluene solution of 5 with $\left[\{\mathrm{Rh}(\mu-\mathrm{Cl})(\mathrm{COD})\}_{2}\right](\mathrm{COD}=1,5$-cyclooctadiene $)$ in the presence of $\mathrm{KOH}$. 


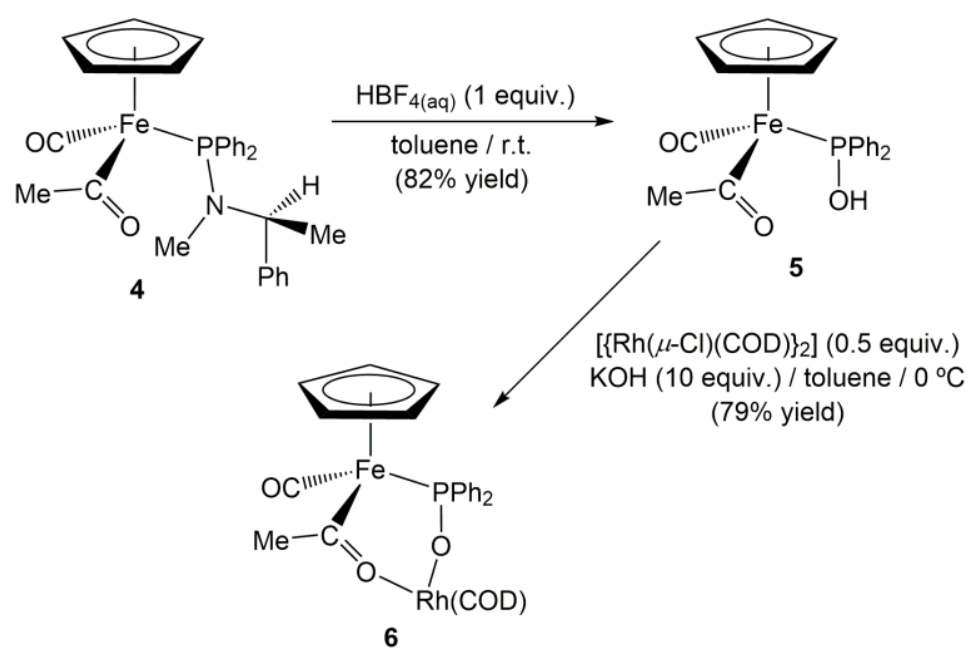

Scheme 2. Hydrolysis of the P-N bond in an iron(II) amino-phosphine complex.

The related cationic $[\mathrm{FeCp}(\mathrm{dppe})]^{+}(\mathrm{dppe}=1,2$-bis(diphenylphosphino)ethane $)$ fragment proved to be also appropriate for the stabilization of the trivalent tautomers of hypophosphorous and phosphorous acid, i.e. $\mathrm{HP}(\mathrm{OH})_{2}$ and $\mathrm{P}(\mathrm{OH})_{3}$, respectively. Thus, the treatment of the chloride precursor $[\mathrm{FeClCp}(\mathrm{dppe})](7)$ with a stoichiometric amount of the corresponding acid $\left(\mathrm{H}_{3} \mathrm{PO}_{2}\right.$ or $\left.\mathrm{H}_{3} \mathrm{PO}_{3}\right)$, in the presence of thallium(I) trifluoromethanesulfonate as the chloride ligand scavenger, resulted in the selective formation of compounds $\left[\mathrm{FeCp}(\mathrm{dppe})\left\{\mathrm{PR}(\mathrm{OH})_{2}\right\}\right][\mathrm{OTf}](\mathrm{R}=\mathrm{H}(\mathbf{8 a}), \mathrm{OH}(\mathbf{8 b}))$ which were isolated in ca. $40 \%$ yield (Scheme 3) [15].

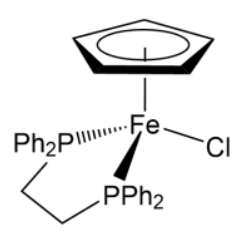

7

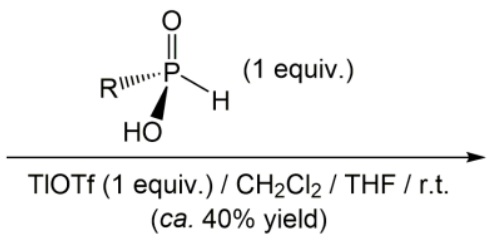

(ca. $40 \%$ yield)

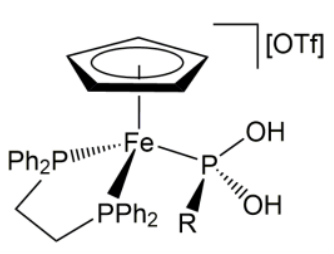

$\mathrm{R}=\mathrm{H}(\mathbf{8} \mathbf{a}), \mathrm{OH}(\mathbf{8 b})$

Scheme 3. Synthesis of $\mathrm{Fe}(\mathrm{II})$ complexes containing $\mathrm{HP}(\mathrm{OH})_{2}$ and $\mathrm{P}(\mathrm{OH})_{3}$ as ligands. 
The formation of complexes $\mathbf{8 a}$ and $\mathbf{8 b}$, along with free phosphorous and hypophosphorous acids, was also observed when acetone or tetrahydrofuran solutions of the mono- and dinuclear compounds 9 and 10, containing phosphorous sesquisulfide $\mathrm{P}_{4} \mathrm{~S}_{3}$ as terminal or bridging ligand (Figure 1), respectively, were treated at room temperature with an excess amount of water [16]. In a similar way, hydrolysis of the tetraphosphorus ligand in the related complexes $\mathbf{1 1}$ and $\mathbf{1 2}$ (Figure 1) led to mixtures of products from which $\left[\mathrm{FeCp}(\mathrm{dppe})\left\{\mathrm{PH}(\mathrm{OH})_{2}\right\}\right]^{+}(\mathbf{8 a})$, free $\mathrm{P}_{4}$ and the phosphine complex $\left[\mathrm{FeCp}(\mathrm{dppe})\left(\mathrm{PH}_{3}\right)\right]^{+}$could be identified [15]. In this context, we must also point out that, while $\left[\mathrm{FeCp}(\mathrm{dppe})\left(\kappa^{1}-\mathrm{P}_{4}\right)\right]\left[\mathrm{PF}_{6}\right](\mathbf{1 1})$ readily reacts with water at room temperature, its pentamethylcyclopentadienyl counterpart $\left[\mathrm{FeCp} *(\mathrm{dppe})\left(\kappa^{1}-\mathrm{P}_{4}\right)\right][\mathrm{Cl}]$, featuring a metallic center with greater electronic density, was found to be resistant to hydrolysis $[16,17]$.

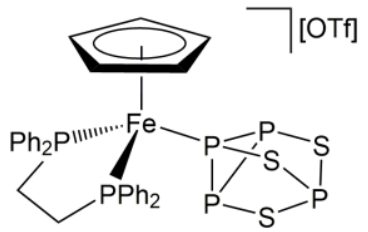

9

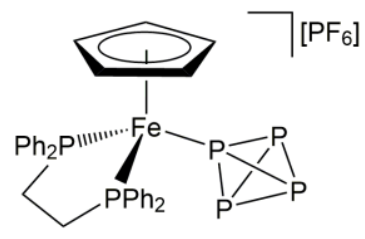

11
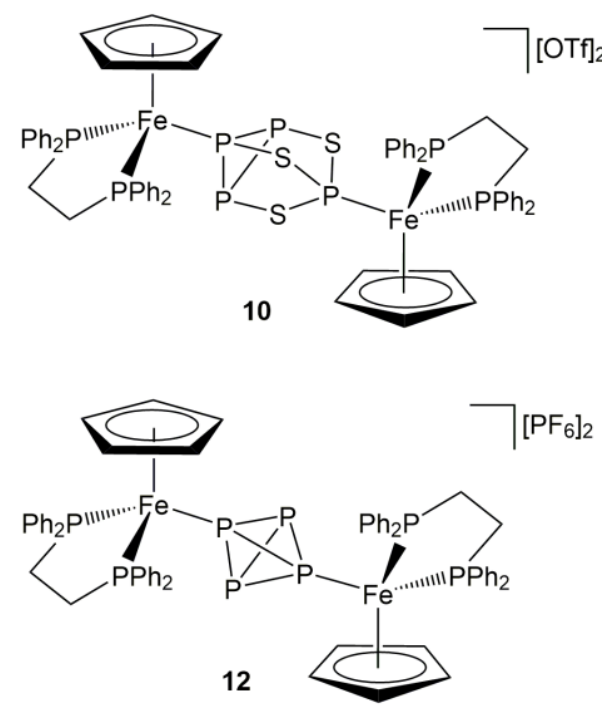

Figure 1. Structure of the cyclopentadienyl-iron(II) complexes 9-12.

In the context of their studies on the coordination chemistry of the pyridinederived tetraphosphine 2,6- $\mathrm{C}_{5} \mathrm{H}_{3} \mathrm{~N}\left[\mathrm{CMe}\left(\mathrm{CH}_{2} \mathrm{PMe}_{2}\right)_{2}\right]_{2}$ (13), Grohmann and co-workers showed that this ligand is susceptible to undergo the selective cleavage of one of its 
phosphorus-carbon bonds by protic reagents and solvents in the presence of iron(II) salts [18]. In particular, in relation with the topic covered in the present review article, they found that the reaction of 13 with $\mathrm{FeX}_{2} \cdot 6 \mathrm{H}_{2} \mathrm{O}\left(\mathrm{X}^{-}=\mathrm{BF}_{4}^{-}, \mathrm{ClO}_{4}^{-}\right)$results in the clean formation of mononuclear complexes $\mathbf{1 4}$, featuring a coordinated dimethylphosphinous acid molecule, and an agostic interaction between the Fe(II) centre and the methyl group generated after the P-C bond cleavage process induced by the $\mathrm{H}_{2} \mathrm{O}$ present in the starting hydrated Fe(II) salts (Scheme 4) [19].

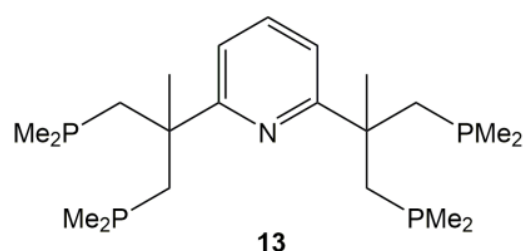

13

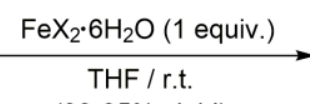

$(93-95 \%$ yield)

$\mathrm{X}^{-}=\mathrm{BF}_{4}^{-}$or $\mathrm{ClO}_{4}^{-}$

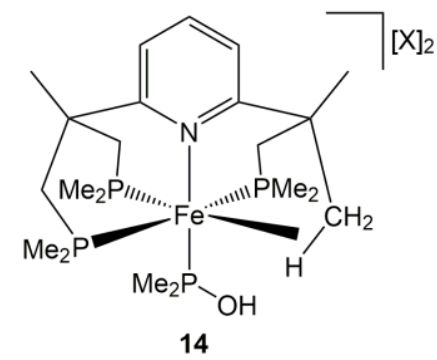

14

Scheme 4. Synthesis of a $\mathrm{Me}_{2} \mathrm{POH}-\mathrm{Fe}(\mathrm{II})$ complex through hydrolytic cleavage of a P-C bond.

An additional example of an iron-phosphinous acid complex is the dinuclear compound $\left[\mathrm{Fe}_{2} \mathrm{Cp}_{2}(\mu-\mathrm{CO})_{2}(\mathrm{CO})\{\mathrm{PHCyOH}\}\right]$ (16) (Scheme 5), a rather reactive species which decomposes easily upon manipulation and that could therefore not be isolated in pure form [20]. Complex 16 was generated by treatment of a dichloromethane solution of the phosphinidene derivative $\left[\mathrm{Fe}_{2} \mathrm{Cp}_{2}(\mu-\mathrm{CO})(\mu-\mathrm{PCy})(\mathrm{CO})_{2}\right](\mathbf{1 5})$ with an excess of water, a reaction that was found to be drastically accelerated in the presence of 1 equivalent of the Lewis acid BEt 3 . As shown in Scheme 5, to account for the formation of $\mathbf{1 6}$ the authors proposed the initial deprotonation of the water molecule by the nucleophilic $\mathrm{P}$ atom of the bridging phosphinidene ligand of $\mathbf{1 5}$ to give a cationic phosphide intermediate A. Subsequently, the positively charged P atom in A undergoes the nucleophilic attack of the hydroxide counterion to generate the corresponding 
PHCyOH-bridged derivative $\mathbf{B}$, which rapidly rearranges into the final reaction product featuring a more stable terminal coordination of the phosphinous acid ligand. In a subsequent study, the same group reported the preparation of the cationic hydroxyphosphide complex $\left[\mathrm{Fe}_{2} \mathrm{Cp}_{2}(\mu-\mathrm{CO})\{\mu-\mathrm{PCyOH}\}(\mathrm{CO})_{2}\right]\left[\mathrm{BF}_{4}\right]$ by protonation of the oxophosphinidene-bridged species $\left[\mathrm{Fe}_{2} \mathrm{Cp}_{2}(\mu-\mathrm{CO})\{\mu-\mathrm{P}(=\mathrm{O}) \mathrm{Cy}\}(\mathrm{CO})_{2}\right]$, generated by oxidation of $\mathbf{1 5}$, with $\mathrm{HBF}_{4} \cdot \mathrm{OEt}_{2}$ [21]. The related dinuclear hydroxyoxyphosphide complex $\left[\mathrm{Fe}_{2} \mathrm{Cp}_{2}(\mu-\mathrm{CO})\{\mu-\mathrm{P}(=\mathrm{O}) \mathrm{OH}\}(\mathrm{CO})_{2}\right]$ is also known [22,23]. It was generated by UV irradiation of an aqueous solution of the phosphinic acid-bridged species $\left[\mathrm{Fe}_{2} \mathrm{Cp}_{2}\left\{\mu-\mathrm{P}(\mathrm{OH})_{2}\right\}(\mathrm{CO})_{4}\right][\mathrm{Br}], \quad$ a compound accessible from $\left[\mathrm{Fe}_{2} \mathrm{Cp}_{2}\{\mu-\right.$ $\left.\left.\mathrm{PH}_{2}\right\}(\mathrm{CO})_{4}\right][\mathrm{Br}]$ upon treatment with aqueous $\mathrm{CBr}_{4}[22]$.

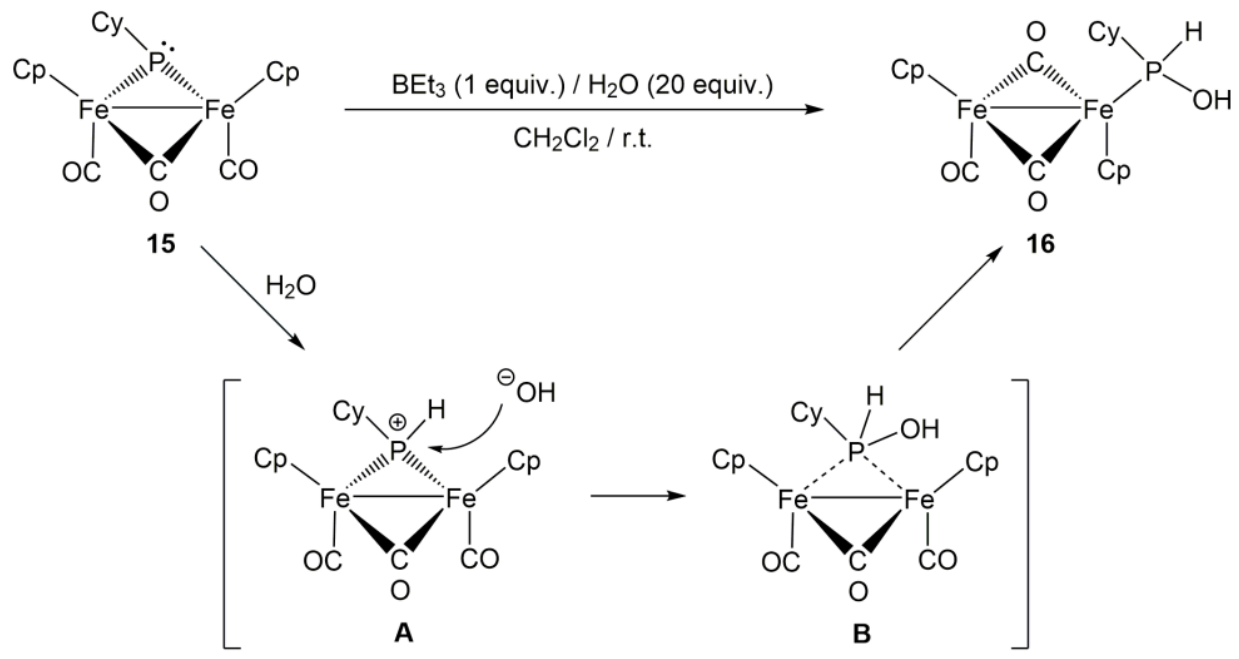

Scheme 5. Generation of the diiron phosphinous acid complex $\mathbf{1 6 .}$

On the other hand, the mononuclear tricarbonyl-Fe(0) derivative $\mathbf{1 7}$, containing $(\mathrm{MeO})_{2} \mathrm{POH}$ as ligand (Figure 2), was synthesized by Cherkasov and co-workers by reacting the chalcone complex $\left[\mathrm{Fe}(\mathrm{CO})_{4}\left\{\eta^{2}-\mathrm{PhCH}=\mathrm{CHC}(=\mathrm{O}) \mathrm{Ph}\right\}\right]$ with dimethyl phosphite $(\mathrm{MeO}){ }_{2} \mathrm{P}(=\mathrm{O}) \mathrm{H}[24]$. The same authors also reported on the reactivity of $\mathbf{1 7}$ towards diazomethane, which resulted in the replacement of the $(\mathrm{MeO})_{2} \mathrm{POH}$ ligand and 
selective formation of the corresponding ethylene complex $\left[\mathrm{Fe}(\mathrm{CO})_{3}\left\{\eta^{2}-\right.\right.$ $\left.\mathrm{PhCH}=\mathrm{CHC}(=\mathrm{O}) \mathrm{Ph}\}\left(\eta^{2}-\mathrm{CH}_{2}=\mathrm{CH}_{2}\right)\right][25]$.

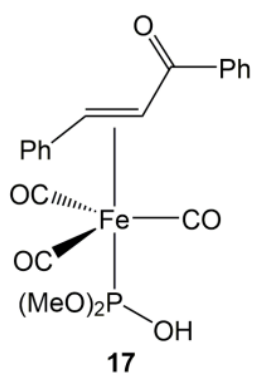

Figure 2. Structure of the dimethylphosphorous acid-iron(0) complex 17.

\section{Synthesis and reactivity of ruthenium complexes}

The number of ruthenium complexes with coordinated $\mathrm{P}-\mathrm{OH}$ ligands reported to date in the literature is comparatively much higher than those of iron and osmium, with $\mathrm{Ru}$ (II) species dominating the scene. In this regard, much attention has been paid to the behavior of dimers $\left[\left\{\mathrm{RuCl}(\mu-\mathrm{Cl})\left(\eta^{6} \text {-arene }\right)\right\}_{2}\right]$ (arene $=$ benzene $(\mathbf{1 8 a}), p$-cymene $(\mathbf{1 8 b})$, mesitylene (18c), hexamethylbenzene (18d)) towards secondary phosphine oxides. Thus, the treatment of these dimers with two equivalents of different symmetrical and unsymmetrical SPOs, in most cases under mild conditions (r.t.), allowed the preparation of a large number of mononuclear complexes of general composition $\left[\mathrm{RuCl}_{2}\left(\eta^{6}-\right.\right.$ arene) $\left.\left(\mathrm{PR}^{1} \mathrm{R}^{2} \mathrm{OH}\right)\right]$ (19-22 in Figure 3$)$, through the classical $\mathrm{P}(=\mathrm{O}) \mathrm{H}$ to $\mathrm{P}-\mathrm{OH}$ tautomerization of the SPOs and cleavage of the chloride bridges of 18a-d [10,26-32]. Similar reactions conducted with phosphites $(\mathrm{RO}){ }_{2} \mathrm{P}(=\mathrm{O}) \mathrm{H}(\mathrm{R}=\mathrm{Me}, \mathrm{Et}, \mathrm{Ph})$ led to the expected mononuclear species $\left[\mathrm{RuCl}_{2}\left(\eta^{6}\right.\right.$-arene $\left.)\left\{\mathrm{P}(\mathrm{OR})_{2} \mathrm{OH}\right\}\right]$ (23-26 in Figure 3) $[26,29,33]$. The related derivatives $\left[\operatorname{RuBr}_{2}\left(\eta^{6}-p\right.\right.$-cymene $\left.)(\mathrm{PRPhOH})\right]\left(\mathrm{R}=\mathrm{Ph}(\mathbf{2 7 a}),{ }^{\mathrm{t}} \mathrm{Bu}\right.$ (27b)) and $\left[\mathrm{RuI}_{2}\left(\eta^{6}-p\right.\right.$-cymene $\left.)(\mathrm{PRPhOH})\right]\left(\mathrm{R}=\mathrm{Ph}(\mathbf{2 8 a}),{ }^{\mathrm{t}} \mathrm{Bu}(\mathbf{2 8 b})\right)$ were analogously synthesized starting from the corresponding ruthenium(II) dimers $\left[\left\{\operatorname{RuX}(\mu-\mathrm{X})\left(\eta^{6}-p\right.\right.\right.$ - 
cymene $\left.)\}_{2}\right](\mathrm{X}=\mathrm{Br}, \mathrm{I})[10,27]$. In addition, treatment of $\left[\left\{\mathrm{RuCl}(\mu-\mathrm{Cl})\left(\eta^{6}-p \text {-cymene }\right)\right\}_{2}\right]$ (18b) with two equivalents of phenylphosphinic acid $\mathrm{PhP}(=\mathrm{O})(\mathrm{OH}) \mathrm{H}$ in refluxing THF allowed the isolation of $\left[\mathrm{RuCl}_{2}\left(\eta^{6}-p\right.\right.$-cymene $\left.)\left\{\mathrm{PPh}(\mathrm{OH})_{2}\right\}\right]$ (78\% yield), which could be easily transformed into $\left[\mathrm{RuCl}_{2}\left(\eta^{6}-p\right.\right.$-cymene $\left.)\left(\mathrm{PPhF}_{2}\right)\right]$ upon treatment with the fluorinating agent $\left[\mathrm{Et}_{2} \mathrm{NSF}_{2}\right]\left[\mathrm{BF}_{4}\right][34]$.

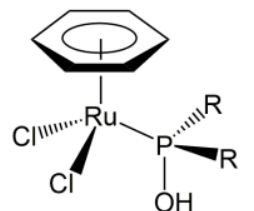

$$
\mathrm{R}=\mathrm{Me}(\mathbf{1 9 a}), \mathrm{Ph}(19 \mathrm{~b})
$$

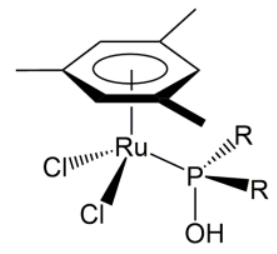

$\mathrm{R}=\mathrm{Me}(\mathbf{2 1} \mathrm{a}), \mathrm{Ph}(\mathbf{2 1 b})$ $\mathrm{CH}_{2} \mathrm{C}_{6} \mathrm{~F}_{5}$ (21c)

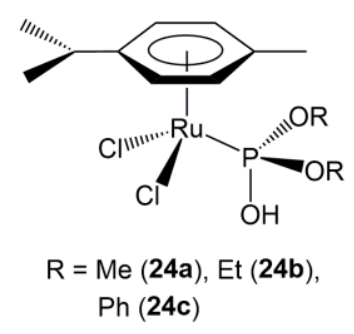

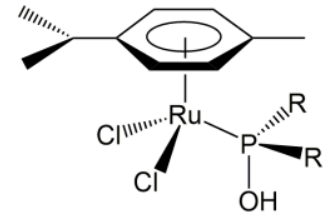

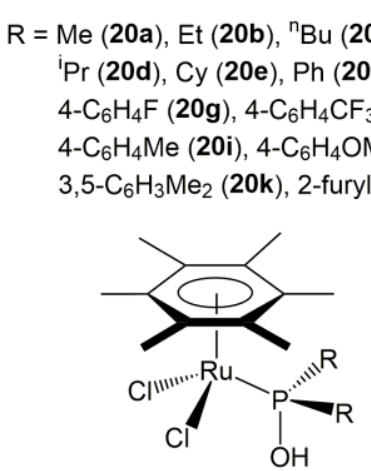

$\mathrm{R}=\mathrm{Me}(\mathbf{2 2 a}), \mathrm{Ph}$ (22b)

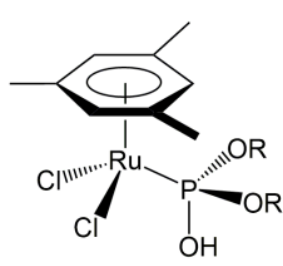

$\mathrm{R}=\mathrm{Me}(\mathbf{2 5 a})$, Et (25b), $\mathrm{Ph}(25 \mathrm{c})$

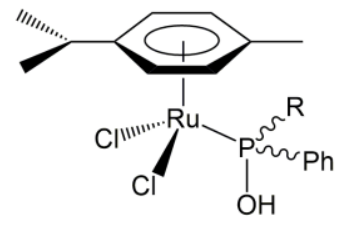

$\mathrm{R}=\mathrm{Me}(20 \mathrm{~m}),{ }^{\mathrm{n}} \mathrm{Bu}$ (20n),

tBu (20o), Cy (20p), $\mathrm{Bn}(\mathbf{2 0 q})$

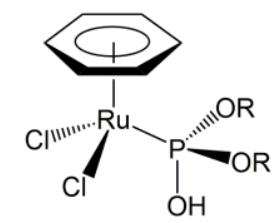

$\mathrm{R}=\mathrm{Me}$ (23a), Et (23b), $\mathrm{Ph}(23 \mathrm{c})$

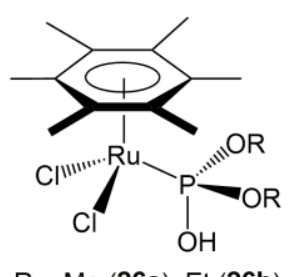

$\mathrm{R}=\mathrm{Me}(\mathbf{2 6 a})$, Et (26b), $\mathrm{Ph}$ (26c)

Figure 3. Structure of the arene-ruthenium(II) complexes 19-26.

The cationic arene-ruthenium(II) complexes $\quad\left[\mathrm{RuCl}\left(\eta^{6}-p-\right.\right.$ cymene $\left.)\left(\mathrm{PPh}_{3}\right)\left(\mathrm{PPh}_{2} \mathrm{OH}\right)\right]\left[\mathrm{PF}_{6}\right]$ and $\left[\mathrm{RuCl}\left(\eta^{6}-\mathrm{C}_{6} \mathrm{Me}_{6}\right)\left\{\mathrm{P}(\mathrm{OMe})_{3}\right\}\left\{\mathrm{P}(\mathrm{OMe})_{2} \mathrm{OH}\right\}\right]\left[\mathrm{PF}_{6}\right]$ are also known. The former was obtained by reacting $\left[\mathrm{RuCl}_{2}\left(\eta^{6}-p\right.\right.$-cymene $\left.)\left(\mathrm{PPh}_{2} \mathrm{OH}\right)\right]$ (20f) with triphenylphosphine in the presence of the chloride abstractor $\mathrm{NaPF}_{6}$ [30], while the latter was generated by protonation of the neutral phosphonate complex 
$\left[\mathrm{RuCl}\left(\eta^{6}-\mathrm{C}_{6} \mathrm{Me}_{6}\right)\left\{\mathrm{P}(\mathrm{OMe})_{3}\right\}\left\{\mathrm{P}(=\mathrm{O})(\mathrm{OMe})_{2}\right\}\right]$ with $\mathrm{HCl}$ and subsequent $\mathrm{Cl}^{-} / \mathrm{PF}_{6}^{-}$ counteranion exchange upon treatment with $\mathrm{NH}_{4} \mathrm{PF}_{6}$ [33].

Interestingly, when the reaction between the hexamethylbenzene-ruthenium(II) dimer $\left[\left\{\mathrm{RuCl}(\mu-\mathrm{Cl})\left(\eta^{6}-\mathrm{C}_{6} \mathrm{Me}_{6}\right)\right\}_{2}\right](\mathbf{1 8 d})$ and dimethylphosphite $(\mathrm{MeO})_{2} \mathrm{P}(=\mathrm{O}) \mathrm{H}$ was performed in refluxing methanol with 4 equivalents of the phosphite, the mononuclear compound $\left[\mathrm{RuCl}\left(\eta^{6}-\mathrm{C}_{6} \mathrm{Me}_{6}\right)\left(\left\{\mathrm{P}(\mathrm{OMe})_{2} \mathrm{O}\right\}_{2} \mathrm{H}\right)\right]$ (29) was selectively formed (Scheme 6) $[33,35]$. This compound formally contains one dimethylphosphorous acid $(\mathrm{MeO})_{2} \mathrm{POH}$ ligand and one dimethylphosphonate $(\mathrm{MeO})_{2} \mathrm{PO}^{-}$anion coordinated to ruthenium, which become indistinguishable as a consequence of their association through a strong intramolecular H-bond.
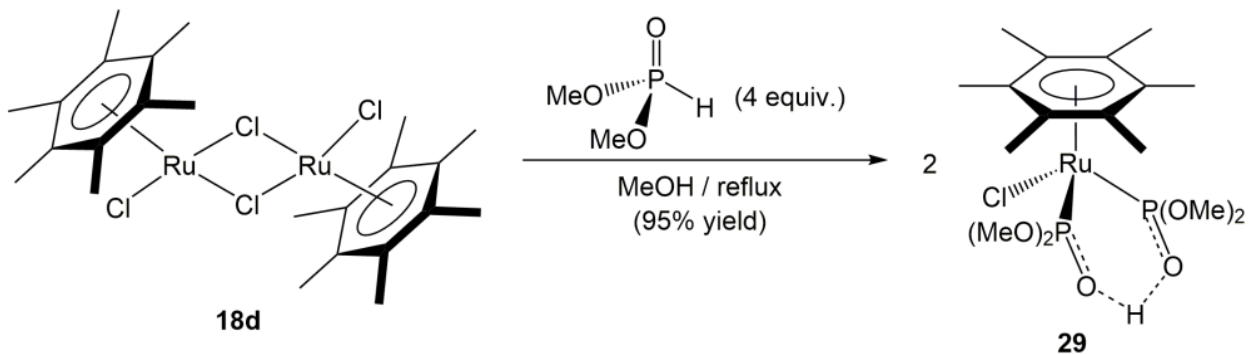

Scheme 6. Synthesis of complex $\left[\mathrm{RuCl}\left(\eta^{6}-\mathrm{C}_{6} \mathrm{Me}_{6}\right)\left(\left\{\mathrm{P}(\mathrm{OMe})_{2} \mathrm{O}\right\}_{2} \mathrm{H}\right)\right](\mathbf{2 9})$.

Compound 29 proved to be an excellent starting material for the preparation of a series of di- and trinuclear heterometallic complexes (30-33 in Figure 4) through its treatment with appropriate metallic precursors $[33,35]$. All these species feature a bisphosphonate anion $\left[\mathrm{RuCl}\left(\eta^{6}-\mathrm{C}_{6} \mathrm{Me}_{6}\right)\left\{\mathrm{P}(=\mathrm{O})(\mathrm{OMe})_{2}\right\}_{2}\right]^{-}$coordinated in a tridentate $\mathrm{O}, \mathrm{O}, \mathrm{Cl}$ manner, which results from the deprotonation (compounds $\mathbf{3 0}, \mathbf{3 2 a - c}$ and $\mathbf{3 3}$ ) or oxidative addition (compounds 31a,b) of the P-O $\cdots \mathrm{H} \cdots \mathrm{O}-\mathrm{P}$ unit of 29. 


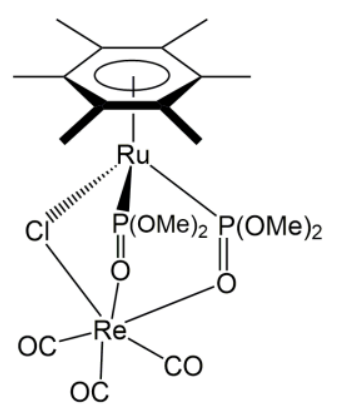

30
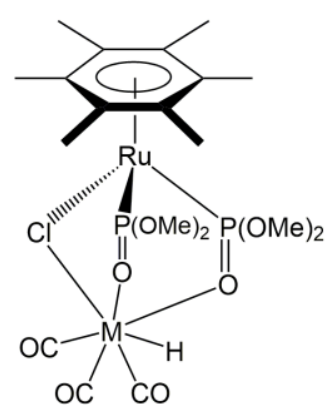

$M=M o(31 a), W(31 b)$

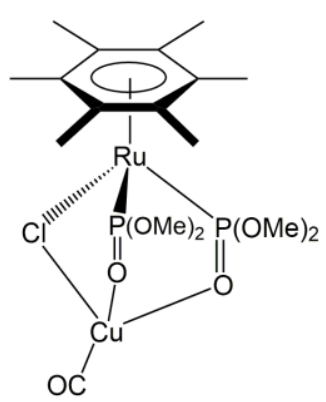

33

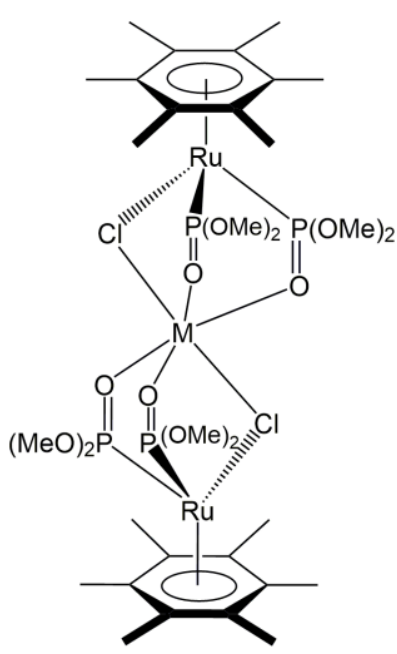

$\mathrm{M}=\mathrm{Cd}(32 \mathrm{a}), \mathrm{Pb}(32 \mathrm{~b}), \mathrm{Cu}(32 \mathrm{c})$

Figure 4. Structure of the heterometallic complexes 30-33.

The related iodide derivatives $\left[\mathrm{RuI}\left(\eta^{6}-\mathrm{C}_{6} \mathrm{R}_{6}\right)\left(\left\{\mathrm{P}(\mathrm{OMe})_{2} \mathrm{O}\right\}_{2} \mathrm{H}\right)\right](\mathrm{R}=\mathrm{H}, \mathrm{Me})$ were also accessible by protonation of the corresponding anionic bis(dimethylphosphonate) complexes $[\mathrm{Na}]\left[\mathrm{RuI}\left(\eta^{6}-\mathrm{C}_{6} \mathrm{R}_{6}\right)\left\{\mathrm{P}(=\mathrm{O})(\mathrm{OMe})_{2}\right\}_{2}\right]$ with $\mathrm{H}_{2} \mathrm{SO}_{4}$ [36]. These compounds react with thallium(I) acetylacetonate $(\mathrm{Tl}(\mathrm{acac}))$ to generate the respective heterobimetallic complexes $\left[\mathrm{RuI}\left(\eta^{6}-\mathrm{C}_{6} \mathrm{R}_{6}\right)\left(\left\{\mathrm{P}(\mathrm{OMe})_{2} \mathrm{O}\right\}_{2} \mathrm{Tl}\right)\right](\mathrm{R}=\mathrm{H}, \mathrm{Me})$, which were employed as precursors for the synthesis of the heterometallic $\mathrm{Ru} / \mathrm{Pt}$ and $\mathrm{Ru} / \mathrm{Sn}$ derivatives 34 and 35 (Figure 5), featuring respectively a tridentate $O, O, I$ - or bidentate $O, O$-coordination of the anionic ruthenium(II) fragments $\left[\mathrm{RuI}\left(\eta^{6}-\right.\right.$ $\left.\left.\mathrm{C}_{6} \mathrm{R}_{6}\right)\left\{\mathrm{P}(=\mathrm{O})(\mathrm{OMe})_{2}\right\}_{2}\right]^{-}$, through transmetalation reactions with $\left[\mathrm{PtIMe}_{3}\right]_{4}$ and $\mathrm{SnCl}_{2}$ [36]. 


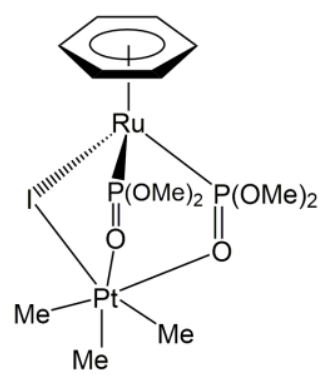

34

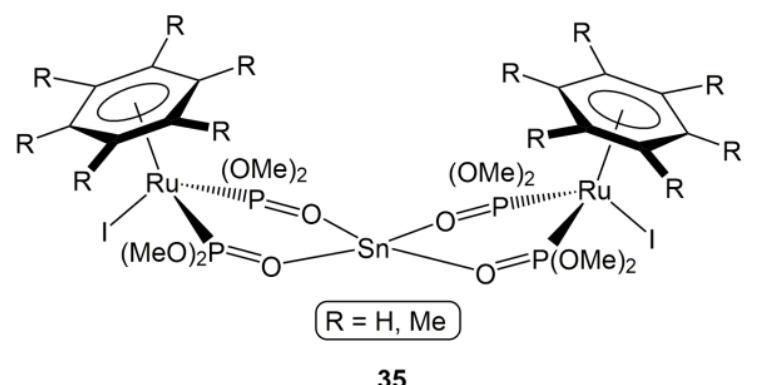

35

Figure 5. Structure of the heterometallic complexes $\mathbf{3 4}$ and $\mathbf{3 5 .}$

The reactivity of the carbonyl-ruthenium(II) dimer $\left[\left\{\mathrm{RuCl}(\mu-\mathrm{Cl})(\mathrm{CO})_{3}\right\}_{2}\right]$ (36) towards secondary phosphine oxides was studied by Buono, Clavier and co-workers [37]. As shown in Scheme 7, depending on the experimental conditions employed different products were formed. Thus, when the reactions were performed in THF at r.t. with only 2 equiv. of the SPOs, complexes $\left[\mathrm{RuCl}_{2}(\mathrm{CO})_{3}\left\{\mathrm{O}=\mathrm{P}(\mathrm{H}) \mathrm{R}^{1} \mathrm{R}^{2}\right\}\right](37)$, in which the SPO coordinates the metal through the oxygen atom, were selectively formed. Conversely, when $\mathbf{3 6}$ was treated with an excess (4 equiv.) of the SPOs under harsh conditions, i.e. in refluxing toluene, bis(phosphinous acid) complexes with general formula $\left[\mathrm{RuCl}_{2}(\mathrm{CO})_{2}\left(\mathrm{PR}^{1} \mathrm{R}^{2} \mathrm{OH}\right)_{2}\right](\mathbf{3 8})$ were in this case obtained. As expected, NMR monitoring of the latter reactions confirmed that compounds $\mathbf{3 7}$ are intermediate species in the formation of complexes 38. Also of note is the fact that complexes 38a-d, generated from racemic unsymmetrically substituted SPOs were isolated as nonseparable mixtures of diastereoisomers in $c a$. 1:1 ratio. On the other hand, no reaction of 36 was found with the highly sterically demanding secondary phosphine oxides ${ }^{\mathrm{t}} \mathrm{Bu}_{2} \mathrm{P}(=\mathrm{O}) \mathrm{H}$ and $\mathrm{Ad}_{2} \mathrm{P}(=\mathrm{O}) \mathrm{H}$. 


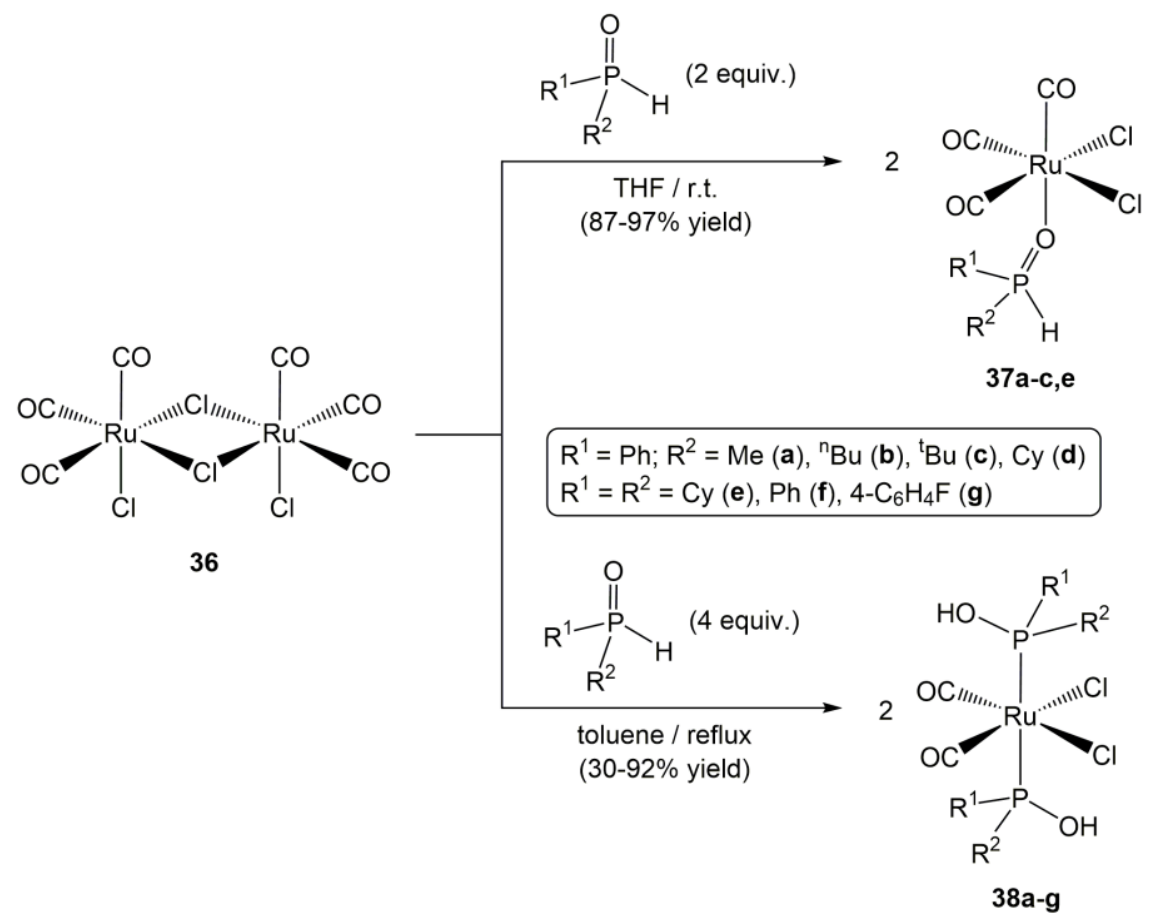

Scheme 7. Reactivity of dimer $\left[\left\{\mathrm{RuCl}(\mu-\mathrm{Cl})(\mathrm{CO})_{3}\right\}_{2}\right](\mathbf{3 6})$ towards SPOs.

A series of cationic cyclopentadienyl-ruthenium(II) complexes 39-42a-b, containing $\mathrm{HP}(\mathrm{OH})_{2}$ and $\mathrm{P}(\mathrm{OH})_{3}$ as ligands, were synthesized by Peruzzini and coworkers starting from the chloride precursors $\left[\mathrm{RuClCpL}_{2}\right]\left(\mathrm{L}=\mathrm{PMe}_{3}, \mathrm{PPh}_{3}, \mathrm{TPPMS} ; \mathrm{L}_{2}\right.$ $=$ dppe; TPPMS $=$ sodium salt of $m$-monosulfonated triphenylphosphine) and hypophosphorous or phosphorous acid (Scheme 8) [38-41]. Further treatment of compounds $\left[\mathrm{RuCp}\left(\mathrm{PPh}_{3}\right)_{2}\left\{\mathrm{PR}(\mathrm{OH})_{2}\right\}\right][\mathrm{OTf}](\mathrm{R}=\mathrm{H}(\mathbf{3 9 a}), \mathrm{OH}(\mathbf{3 9 b}))$ with an excess of the corresponding acid, in $\mathrm{THF}$ at $50^{\circ} \mathrm{C}$, resulted in the clean displacement of one of the triphenylphosphine ligands and isolation of the respective complexes $\left[\mathrm{RuCp}\left(\mathrm{PPh}_{3}\right)\left\{\mathrm{PR}(\mathrm{OH})_{2}\right\}_{2}\right][\mathrm{OTf}](\mathrm{R}=\mathrm{H}, \mathrm{OH})$ in high yield $(85-90 \%)$. Complexes 39a-b were alternatively isolated as the corresponding hexafluorophosphate salts, i.e. $\left[\mathrm{RuCp}\left(\mathrm{PPh}_{3}\right)_{2}\left\{\mathrm{PR}(\mathrm{OH})_{2}\right\}\right]\left[\mathrm{PF}_{6}\right](\mathrm{R}=\mathrm{H}, \mathrm{OH})$, by performing the reactions of [RuClCp$\left(\mathrm{PPh}_{3}\right)_{2}$ ] with $\mathrm{H}_{3} \mathrm{PO}_{2}$ or $\mathrm{H}_{3} \mathrm{PO}_{3}$ using $\mathrm{AgPF}$, instead of TlOTf, as the chloride abstractor. However, these salts were found to be relatively unstable in solution 
evolving into $\left[\mathrm{RuCp}\left(\mathrm{PPh}_{3}\right)_{2}\left\{\mathrm{PH}(\mathrm{OH})_{2}\right\}\right]\left[\mathrm{PF}_{2} \mathrm{O}_{2}\right]$ and $\left[\mathrm{RuCp}\left(\mathrm{PPh}_{3}\right)_{2}\left\{\mathrm{PF}(\mathrm{OH})_{2}\right\}\right]\left[\mathrm{PF}_{2} \mathrm{O}_{2}\right]$, respectively, due to partial hydrolysis of the hexafluophosphate anion by adventitious water [38]. The HF liberated in the process was responsible for the transformation of the coordinated $\mathrm{P}(\mathrm{OH})_{3}$ ligand into $\mathrm{PF}(\mathrm{OH})_{2}$, the latter being the tautomer of the extremely unstable monofluorophosphorous acid $\mathrm{HP}(=\mathrm{O}) \mathrm{F}(\mathrm{OH})$ [42]. The same decomposition process was also observed when a dichloromethane solution of $\left[\mathrm{RuCp}(\mathrm{dppe})\left\{\mathrm{P}(\mathrm{OH})_{3}\right\}\right]\left[\mathrm{PF}_{6}\right](\mathbf{4 2 b})$ was left at room temperature for $20 \mathrm{~h}$, allowing the isolation of $\left[\mathrm{RuCp}(\mathrm{dppe})\left\{\mathrm{PF}(\mathrm{OH})_{2}\right\}\right]\left[\mathrm{PF}_{2} \mathrm{O}_{2}\right]$ in moderate yield (42\%) [39].
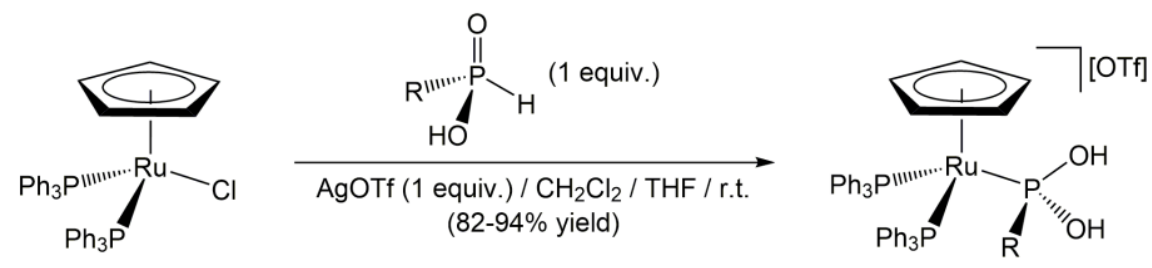

$$
\mathrm{R}=\mathrm{H}(39 \mathrm{a}), \mathrm{OH}(39 \mathrm{~b})
$$
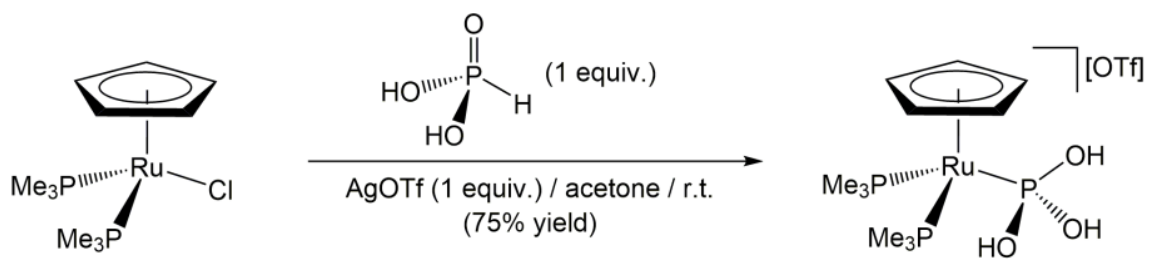

$40 \mathrm{~b}$
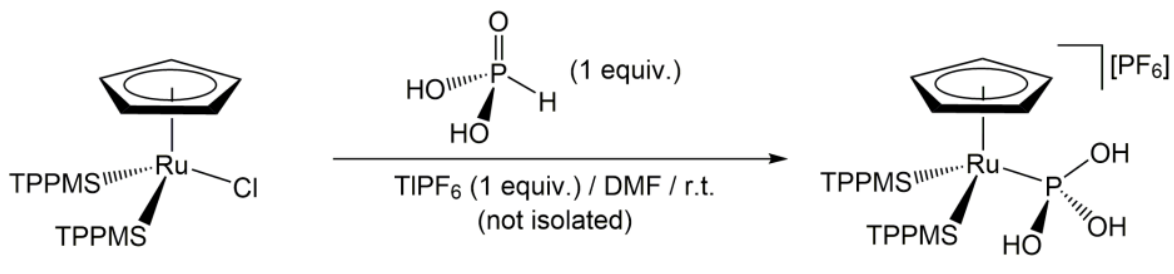

TPPMS $=$ sodium salt of $m$-monosulfonated triphenylphosphine

41b
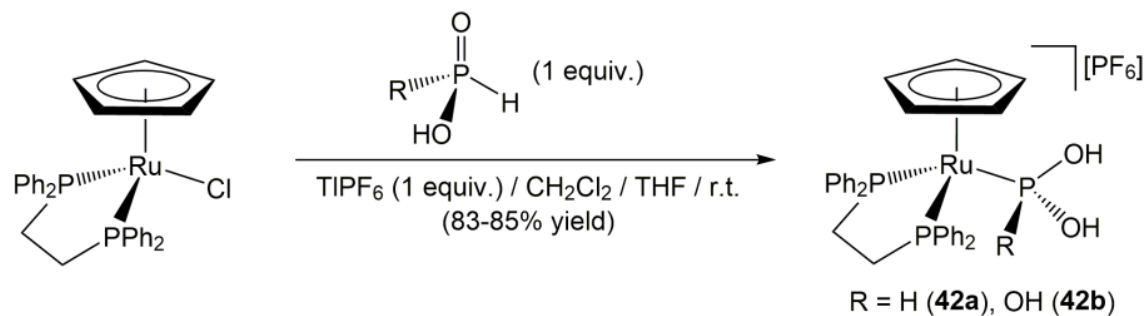

Scheme 8. Synthesis of the cyclopentadienyl-ruthenium(II) complexes 39-42a-b. 
A remarkable result in the field was obtained in the stabilization of the elusive and poorly investigated phosphine oxide $\mathrm{H}_{3} \mathrm{P}=\mathrm{O}$ [43]. This compound could be generated from white phosphorus through a two-step process involving the initial electroreduction of $\mathrm{P}_{4}$ into $\mathrm{PH}_{3}$ in aqueous medium, followed by electrochemical oxidation. $\mathrm{H}_{3} \mathrm{P}=\mathrm{O}$ was found to be unstable in aqueous solution, disproportionating spontaneously into $\mathrm{PH}_{3}$ and $\mathrm{H}_{3} \mathrm{PO}_{2}$. However, in the presence of the water-soluble cyclopentadienyl-ruthenium(II) complexes $\left[\mathrm{RuClCp}(\mathrm{TPPMS})_{2}\right]$ and $\left[\mathrm{RuCp}(\mathrm{PTA})(\mathrm{NCMe})_{2}\right]\left[\mathrm{PF}_{6}\right](\mathrm{PTA}=1,3,5$-triazaphosphaadamantane), it could be trapped, as the corresponding $\mathrm{H}_{2} \mathrm{POH}$ tautomer, upon coordination to ruthenium. The resulting complexes, i.e. $\left[\mathrm{RuCp}(\mathrm{TPPMS})_{2}\left(\mathrm{PH}_{2} \mathrm{OH}\right)\right]\left[\mathrm{PF}_{6}\right]$ (43) and $\left[\mathrm{RuCp}(\mathrm{PTA})(\mathrm{NCMe})\left(\mathrm{PH}_{2} \mathrm{OH}\right)\right]\left[\mathrm{PF}_{6}\right]$ (44), were perfectly stable and fully characterized.

The tautomerization of compounds $\mathrm{H}_{\mathrm{n}} \mathrm{P}(=\mathrm{O})(\mathrm{OH})_{3-\mathrm{n}}(\mathrm{n}=1,2,3)$ into the corresponding species $\mathrm{H}_{n} \mathrm{P}(\mathrm{OH})_{3-\mathrm{n}}(\mathrm{n}=0,1,2)$ was computationally evaluated through Density Functional Theory (DFT) calculations, both in the free state and promoted by the model $\mathrm{Ru}(\mathrm{II})$ complex $\left[\mathrm{RuCp}\left(\mathrm{PH}_{3}\right)_{2}\left(\mathrm{OH}_{2}\right)\right]^{+}$, by Peruzzini, Mealli and co-workers [44]. The tautomerization process, disfavored for the free molecules, was found to be much easier to achieve upon coordination to the $\left[\mathrm{RuCp}\left(\mathrm{PH}_{3}\right)_{2}\right]^{+}$fragment, with reduction of the energy barriers of up to one fourth. For the metal assisted reactions (Scheme 9), the calculations indicated that compounds $\mathrm{H}_{\mathrm{n}} \mathrm{P}(=\mathrm{O})(\mathrm{OH})_{3-\mathrm{n}}$ initially coordinate the metal through the oxygen atom leading to intermediates $\mathbf{C}$, which evolve into the corresponding ruthenium(IV) hydrides $\mathbf{D}$ by oxidative addition of the $\mathrm{P}-\mathrm{H}$ bond. Final migration of the hydride ligand to the oxygen atom, through transition state $\mathbf{E}$, leads to the tautomerized ligands with concomitant reduction of the ruthenium center. 

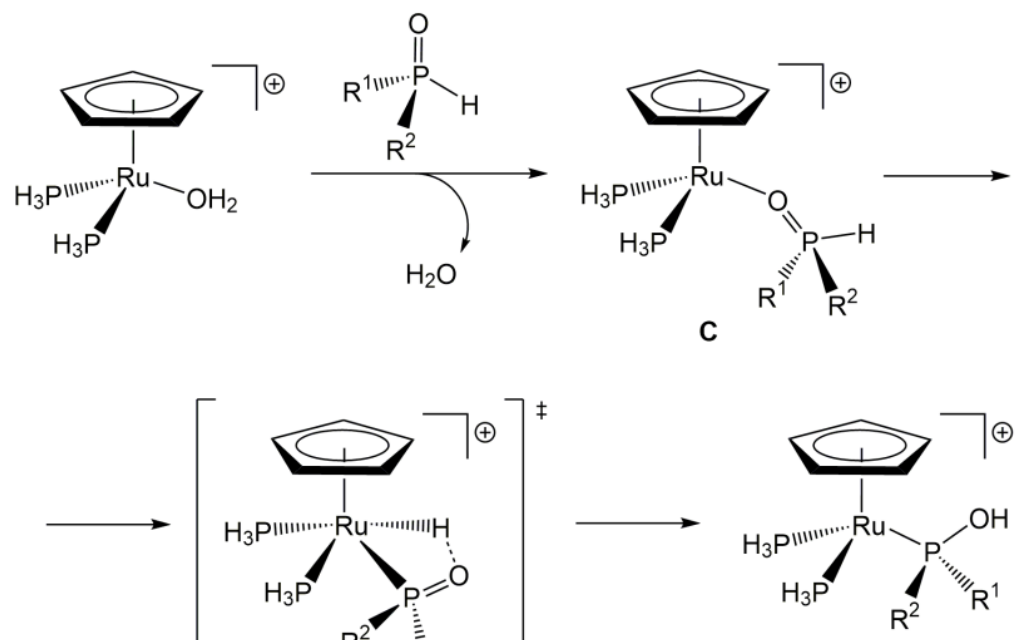

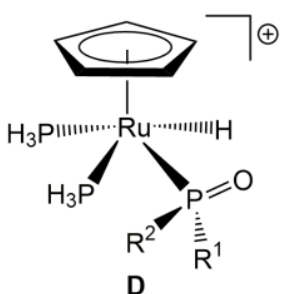

$\mathrm{R}^{1}=\mathrm{R}^{2}=\mathrm{H}, \mathrm{OH}$

$\mathrm{R}^{1}=\mathrm{H}, \mathrm{R}^{2}=\mathrm{OH}$

Scheme 9. Calculated reaction pathway for the tautomerization of phosphine oxide, and hypophosphorous and phosphorous acids on the coordination sphere of ruthenium.

The reactivity of the cyclopentadienyl-ruthenium(II) complexes [ $\left.\mathrm{RuClCp}\left(\mathrm{PPh}_{3}\right)_{2}\right]$, $\left[\mathrm{RuCp}(\mathrm{NCMe})_{3}\right]\left[\mathrm{PF}_{6}\right]$ and $\left[\mathrm{RuCp} *(\mathrm{NCMe})_{3}\right]\left[\mathrm{PF}_{6}\right]$ towards phenylphosphinic acid $\mathrm{PhP}(=\mathrm{O})(\mathrm{OH}) \mathrm{H}$ has also been reported, allowing the isolation of compounds $\left[\mathrm{RuCp}\left(\mathrm{PPh}_{3}\right)_{2}\left\{\mathrm{PPh}(\mathrm{OH})_{2}\right\}\right][\mathrm{OTf}], \quad\left[\mathrm{RuCp}(\mathrm{NCMe})_{2}\left\{\mathrm{PPh}(\mathrm{OH})_{2}\right\}\right]\left[\mathrm{PF}_{6}\right] \quad$ and $\left[\mathrm{RuCp} *(\mathrm{NCMe})\left\{\mathrm{PPh}(\mathrm{OH})_{2}\right\}_{2}\right]\left[\mathrm{PF}_{6}\right]$, respectively [34]. In addition, as previously observed with $\left[\mathrm{RuCl}_{2}\left(\eta^{6}-p\right.\right.$-cymene) $\left.\left\{\mathrm{PPh}(\mathrm{OH})_{2}\right\}\right]$ (see above), the coordinated $\mathrm{PPh}(\mathrm{OH})_{2}$ ligand could be cleanly converted into the corresponding difluorinated phosphine $\mathrm{PPhF}_{2}$ by treatment of dichloromethane solutions of these compounds with $\left[\mathrm{Et}_{2} \mathrm{NSF}_{2}\right]\left[\mathrm{BF}_{4}\right]$ [34]. Related deoxofluorination reactions of $\left[\mathrm{Ru}\left(\mathrm{PPh}_{3}\right)_{2}\left\{\mathrm{PH}(\mathrm{OH})_{2}\right\}\right][\mathrm{OTf}]$ and $\left[\mathrm{Ru}\left(\mathrm{PPh}_{3}\right)_{2}\left\{\mathrm{P}(\mathrm{OH})_{3}\right\}\right][\mathrm{OTf}]$ with $\left[\mathrm{Et}_{2} \mathrm{NSF}_{2}\right]\left[\mathrm{BF}_{4}\right]$, leading to $\left[\mathrm{Ru}\left(\mathrm{PPh}_{3}\right)_{2}\left(\mathrm{PHF}_{2}\right)\right][\mathrm{OTf}]$ and $\left[\mathrm{Ru}\left(\mathrm{PPh}_{3}\right)_{2}\left(\mathrm{PF}_{3}\right)\right][\mathrm{OTf}]$, respectively, were also described [34].

On the other hand, Koelle and co-workers studied the behavior of the Ru(II) dimer $\left[\left\{\mathrm{RuCp}^{*}(\mu-\mathrm{OMe})\right\}_{2}\right]$ towards $\mathrm{Ph}_{2} \mathrm{P}(=\mathrm{O}) \mathrm{H}$, observing the clean formation of the mononuclear compound $\left[\mathrm{RuCp} *\left\{\left(\mathrm{PPh}_{2} \mathrm{O}\right)_{3} \mathrm{H}_{2}\right\}\right]$ (45), which formally contains two 
$\mathrm{PPh}_{2} \mathrm{OH}$ and one $\mathrm{PPh}_{2} \mathrm{O}^{-}$units connected through intramolecular $\mathrm{H}$-bonds (Figure 6) [45]. Similarly, the treatment of $\left[\{\mathrm{RuCp} *(\mu-\mathrm{OMe})\}_{2}\right]$ with an excess of the dialkylphosphites $(\mathrm{RO})_{2} \mathrm{P}(=\mathrm{O}) \mathrm{H}\left(\mathrm{R}=\mathrm{Me}, \mathrm{Et},{ }^{\mathrm{i}} \mathrm{Pr}\right)$ yielded the analogous complexes 46 (Figure 6). All these species can be deprotonated with $\mathrm{NaH}$ to generate the corresponding dianions $\left[\mathrm{RuCp} *\left(\mathrm{PPh}_{2} \mathrm{O}\right)_{3}\right]^{2-}$ and $\left[\mathrm{RuCp} *\left\{\mathrm{P}(\mathrm{OR})_{2} \mathrm{O}\right\}_{3}\right]^{2-}$, which proved to be useful tripod ligands for coordination in vanadium, titanium and ruthenium centers [45].

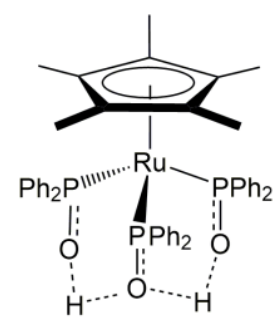

45

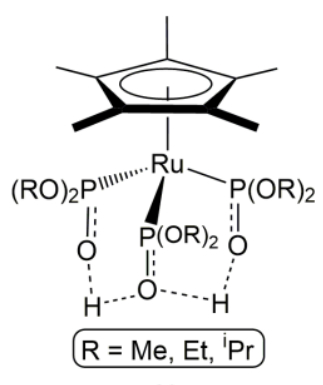

46

Figure 6. Structure of the pentamethylcyclopentadienyl-ruthenium(II) complexes 45-46.

The tautomeric equilibrium between $(\mathrm{EtO})_{2} \mathrm{P}(=\mathrm{O}) \mathrm{H}$ and $\mathrm{P}(\mathrm{OEt})_{2} \mathrm{OH}$, as well as that of $\mathrm{H}_{3} \mathrm{PO}_{3}$ and $\mathrm{P}(\mathrm{OH})_{3}$, in the presence of the aquopentaamine-Ru(II) complex $\left[\mathrm{Ru}\left(\mathrm{NH}_{3}\right)_{5}\left(\mathrm{H}_{2} \mathrm{O}\right)\right]\left[\mathrm{PF}_{6}\right]_{2}$ was studied by Franco and co-workers [46]. Although they were not isolated, the corresponding complexes trans$\left[\mathrm{Ru}\left(\mathrm{NH}_{3}\right)_{4}\left(\mathrm{H}_{2} \mathrm{O}\right)\left\{\mathrm{P}(\mathrm{OEt})_{2} \mathrm{OH}\right\}\right]\left[\mathrm{PF}_{6}\right]_{2}$ and trans- $\left[\mathrm{Ru}\left(\mathrm{NH}_{3}\right)_{4}\left(\mathrm{H}_{2} \mathrm{O}\right)\left\{\mathrm{P}(\mathrm{OH})_{3}\right\}\right]\left[\mathrm{PF}_{6}\right]_{2}$, respectively, could be identified in solution. Nonetheless, when the reaction of complex $\left[\mathrm{Ru}\left(\mathrm{NH}_{3}\right)_{5}\left(\mathrm{H}_{2} \mathrm{O}\right)\right]\left[\mathrm{PF}_{6}\right]_{2}$ with phosphorous acid $\left(\mathrm{H}_{3} \mathrm{PO}_{3}\right)$ was performed in acidic media $\left(\mathrm{CF}_{3} \mathrm{CO}_{2} \mathrm{H} / \mathrm{HCl}\right.$ mixture), in the presence of $\mathrm{NaNO}_{2}$, the nitrosyl complex trans$\left[\mathrm{Ru}(\mathrm{NO})\left(\mathrm{NH}_{3}\right)_{4}\left\{\mathrm{P}(\mathrm{OH})_{3}\right\}\right]\left[\mathrm{Cl}_{3}\right]$ could be isolated and fully characterized [47]. This compound was found to be unstable in aqueous solution for long periods liberating $\mathrm{H}_{3} \mathrm{PO}_{3}$ and generating the nitrosyl-aqua complex trans- $\left[\mathrm{Ru}(\mathrm{NO})\left(\mathrm{NH}_{3}\right)_{4}\left(\mathrm{H}_{2} \mathrm{O}\right)\right]^{3+}$. 
According to spectroscopic data and DFT calculations, the dissociation of the $\mathrm{P}(\mathrm{OH})_{3}$ ligand involves its initial deprotonation to form trans-[Ru(NO) $\left.\left(\mathrm{NH}_{3}\right)_{4}\left\{\mathrm{P}(\mathrm{O})(\mathrm{OH})_{2}\right\}\right]^{2+}$ (intermediate $\mathbf{F}$ in Scheme 10), which isomerizes into the O-bonded linkage isomer trans- $\left[\mathrm{Ru}(\mathrm{NO})\left(\mathrm{NH}_{3}\right)_{4}\left\{\mathrm{OP}(\mathrm{OH})_{2}\right\}\right]^{2+}(\mathbf{G})$. Final protonation of $\mathbf{G}$ generates trans$\left[\mathrm{Ru}(\mathrm{NO})\left(\mathrm{NH}_{3}\right)_{4}\left\{\mathrm{OP}(\mathrm{H})(\mathrm{OH})_{2}\right\}\right]^{3+}(\mathbf{H})$ from which the coordinated molecule of phosphorous acid is displaced by water (Scheme 10). A similar behavior was also observed by Franco and co-workers for the related carbonyl complex trans$\left[\mathrm{Ru}(\mathrm{CO})\left(\mathrm{NH}_{3}\right)_{4}\left\{\mathrm{P}(\mathrm{OH})_{3}\right\}\right]^{2+}$ (generated by reacting $\left[\mathrm{Ru}\left(\mathrm{NH}_{3}\right)_{5}\left(\mathrm{H}_{2} \mathrm{O}\right)\right]^{2+}$ with $\mathrm{H}_{3} \mathrm{PO}_{3}$ under $\mathrm{CO}$ atmosphere) [48].

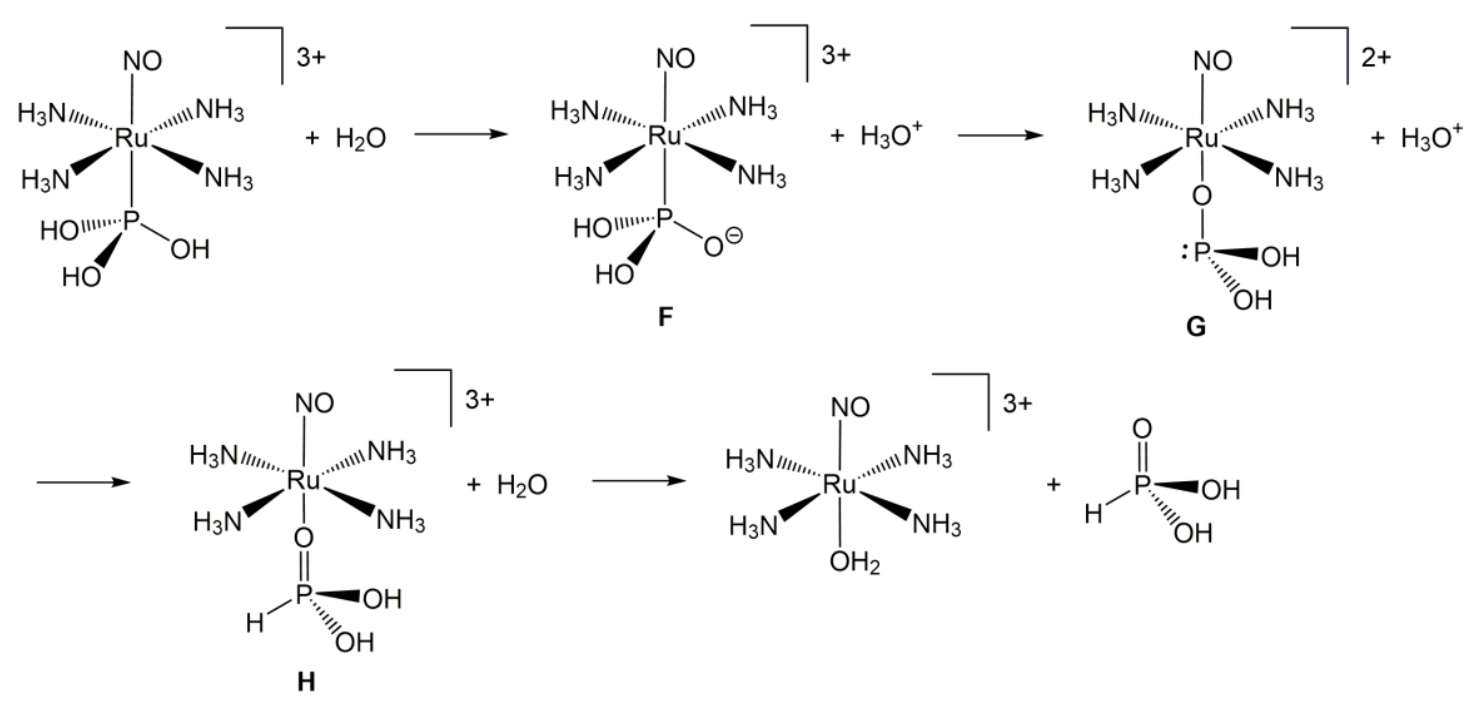

Scheme 10. Proposed reaction pathway for the dissociation of phosphorous acid from trans$\left[\mathrm{Ru}(\mathrm{NO})\left(\mathrm{NH}_{3}\right)_{4}\left\{\mathrm{P}(\mathrm{OH})_{3}\right\}\right]^{3+}$ in aqueous solution.

The behavior of complex $\left[\mathrm{Ru}\left(\mathrm{NH}_{3}\right)_{5}\left(\mathrm{H}_{2} \mathrm{O}\right)\right]\left[\mathrm{PF}_{6}\right]_{2}$ towards diethyl phosphite $(\mathrm{EtO})_{2} \mathrm{P}(=\mathrm{O}) \mathrm{H}$ under $\mathrm{NO}$ atmosphere and in the presence of $\mathrm{NH}_{4} \mathrm{PF}_{6}$ was also evaluated, allowing the isolation of trans-[Ru(NO) $\left.\left(\mathrm{NH}_{3}\right)_{4}\left\{\mathrm{P}(=\mathrm{O})(\mathrm{OEt})_{2}\right\}\right]\left[\mathrm{PF}_{6}\right]_{2}$ instead of the expected trans- $\left[\mathrm{Ru}(\mathrm{NO})\left(\mathrm{NH}_{3}\right)_{4}\left\{\mathrm{P}(\mathrm{OEt})_{2}(\mathrm{OH})\right\}\right]\left[\mathrm{PF}_{6}\right]_{3}$ complex [49]. Nonetheless, the latter was found to be accessible by hydrolysis of the coordinated triethyl phosphite 
ligand in trans $-\left[\mathrm{Ru}(\mathrm{NO})\left(\mathrm{NH}_{3}\right)_{4}\left\{\mathrm{P}(\mathrm{OEt})_{3}\right\}\right]\left[\mathrm{PF}_{6}\right]_{3}$, a reaction that was found to occur both in aqueous solution [50] and in the solid state after prolonged exposure to air [51]. Related P-OR hydrolysis processes were also observed in aqueous solution for the trialkylphosphite complexes trans $-\left[\mathrm{Ru}(\mathrm{NO})\left(\mathrm{NH}_{3}\right)_{4}\left\{\mathrm{P}(\mathrm{OR})_{3}\right\}\right]\left[\mathrm{PF}_{6}\right]_{3}\left(\mathrm{R}=\mathrm{Me},{ }^{\mathrm{i} P r},{ }^{\mathrm{n}} \mathrm{Bu}\right)$ [50].

In the context of their studies on the cooperative heteroatom-hydrogen bonds activation with transition metal carbene complexes [52], Gessner and co-workers studied the reactivity of the nucleophilic ruthenium(II)-carbene derivative $\mathbf{4 7}$ towards aromatic SPOs (Scheme 11) [53]. The reactions, performed in toluene at room temperature, resulted in the expected neat addition of the P-H bond of the SPOs across the $\mathrm{Ru}=\mathrm{C}$ bond of $\mathbf{4 7}$, thus allowing the isolation of the novel phosphinito complexes 48. DFT calculations revealed that, in contrast to other heteroatom-hydrogen bond activation reactions with this type of carbene complexes [52], no concerted 1,2-addition across the metal-carbon double bond was in this case operative. Instead, the process involves the initial coordination of the phosphinous acid tautomer to ruthenium (intermediate I in Scheme 11), followed by hydrogen transfer from the hydroxyl group of the $\mathrm{PR}_{2} \mathrm{OH}$ ligand to the carbenic carbon atom.

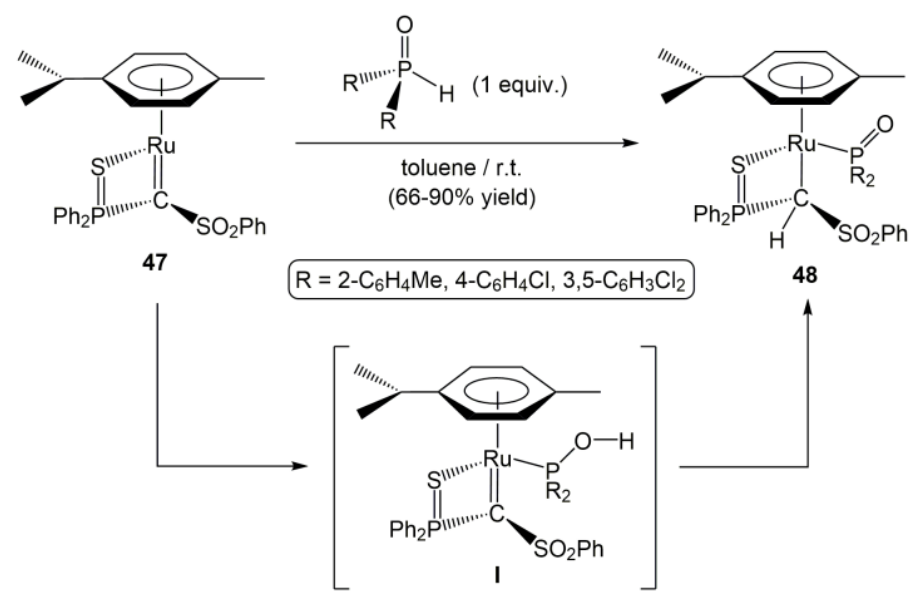

Scheme 11. Reactivity of the carbene-ruthenium(II) complex $\mathbf{4 7}$ towards SPOs. 
On the other hand, despite the growing interest in the use of optically active SPOs as auxiliary ligands in asymmetric catalysis [7a,d], their coordination chemistry has been the subject of very few studies. In this context, the reactivity of enantiomerically pure $(S)$ - and $(R)-{ }^{\mathrm{t}} \mathrm{BuMeP}(=\mathrm{O}) \mathrm{H}$ towards the arene-ruthenium(II) dimer $[\{\mathrm{RuCl}(\mu$ $\mathrm{Cl})\left(\eta^{6}-p\right.$-cymene $\left.\left.)\right\}_{2}\right]$ (18b) was described independently by the groups of Leung and Grabulosa [54,55]. As shown in Scheme 12, the corresponding phosphinous acid tautomers coordinate to ruthenium with complete retention of the configuration at the phosphorous atom, thus affording selectively the optically pure complexes $(R)$ - and $(S)$ 20r, respectively (please note that upon coordination to ruthenium the priority order of the different groups linked to the stereogenic $\mathrm{P}$ atom changes).

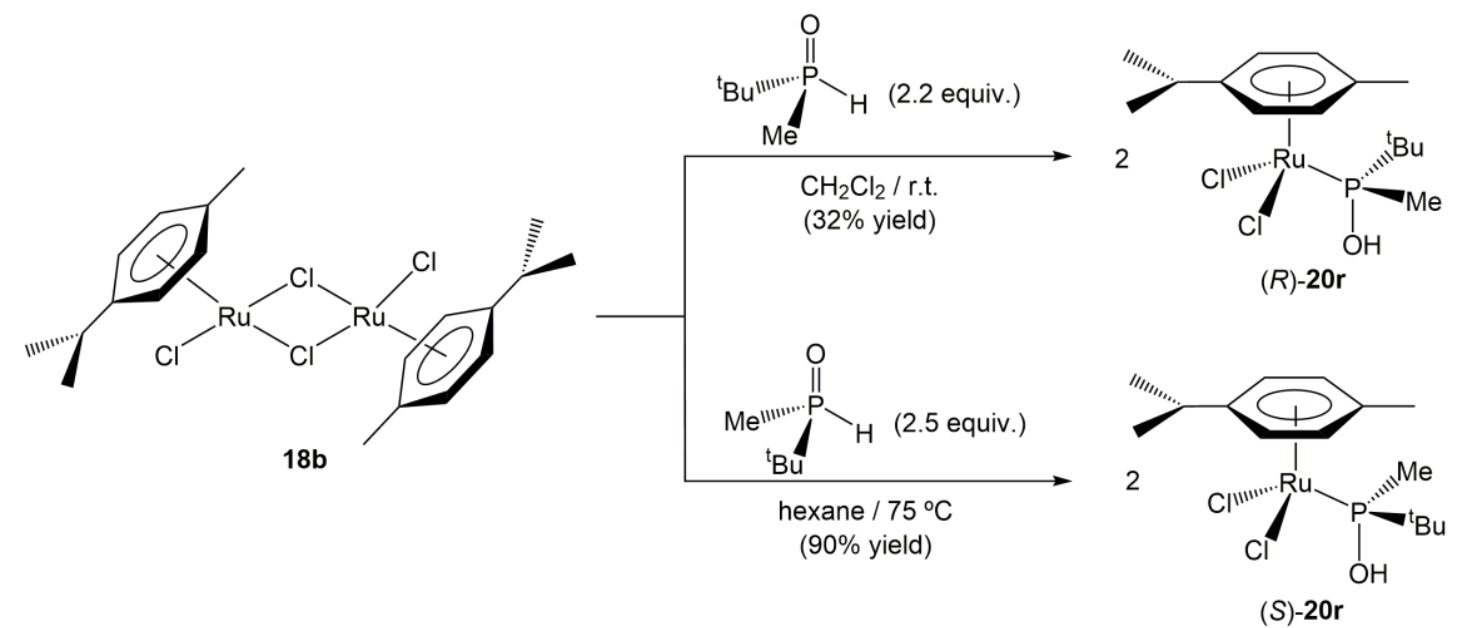

Scheme 12. Reactivity of $\left[\left\{\operatorname{RuCl}(\mu-\mathrm{Cl})\left(\eta^{6}-p \text {-cymene }\right)\right\}_{2}\right]$ (18b) towards optically pure ${ }^{\mathrm{t}} \mathrm{BuMeP}(=\mathrm{O}) \mathrm{H}$.

Retention of the configuration at the phosphorous atom was also observed in the reactions of $\left[\left\{\operatorname{RuCl}(\mu-\mathrm{Cl})(\mathrm{CO})_{3}\right\}_{2}\right](36)$ with optically pure $(S)-{ }^{t} \mathrm{BuPhP}(=\mathrm{O}) \mathrm{H}$ and $(S)$ ${ }^{t} \mathrm{BuMeP}(=\mathrm{O}) \mathrm{H}$, which led to the formation of the mononuclear complexes $(R, R)$ - 
$\left[\mathrm{RuCl}_{2}(\mathrm{CO})_{2}\left\{\mathrm{PR}^{\mathrm{t} B u O H}\right\}\right](\mathrm{R}=\mathrm{Ph}(\mathbf{3 8 c}), \mathrm{Me}(\mathbf{3 8 h}))$ as single stereoisomers (Figure 7) $[37,55]$.

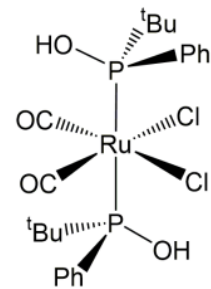

$(R, R)-38 \mathrm{c}$

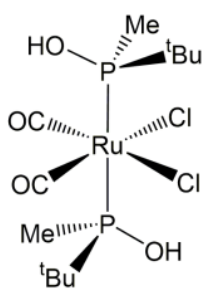

$(R, R)-38 \mathrm{~h}$

Figure 7. Structure of the ruthenium(II) complexes $(R, R)-\mathbf{3 8 \mathbf { c }}$ and $(R, R)-\mathbf{3 8 h}$.

The hydrolytic transformation of P-OR bonds of phosphites, and related $P$-donor ligands, into P-OH ones is well-documented in the chemistry of ruthenium. An early example was described by Gould, Stephenson and co-workers with the preparation of compounds 50a-c by pyrolysis of methanolic solutions containing the cationic trihalidebridged $\mathrm{Ru}(\mathrm{II})$ dinuclear derivatives 49a-c (Scheme 13) [56]. Complexes 50a-c are the result of the partial hydrolysis of the $\mathrm{PPh}_{2}(\mathrm{OR})(\mathrm{R}=\mathrm{Me}, \mathrm{Et})$ ligands present in 49a-c due to the presence of traces of water in the solvent.
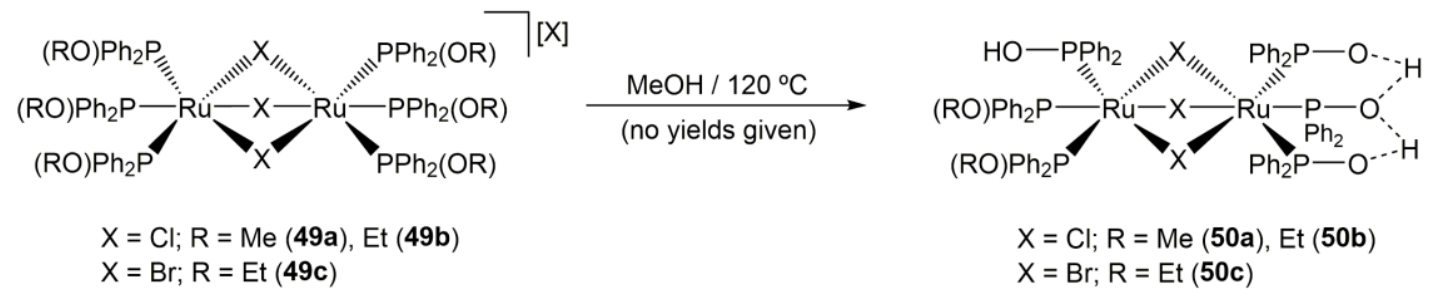

Scheme 13. Pyrolysis of the dinuclear ruthenium(II) complexes 49a-c.

The nitrosyl-ruthenium(II) dimers 51a-b, featuring bidentate ligands derived from the intramolecular hydrogen-bonding association of neutral $\mathrm{PR}(\mathrm{OEt})(\mathrm{OH})$ and anionic $\mathrm{P}(=\mathrm{O}) \mathrm{R}(\mathrm{OEt})$ units $(\mathrm{R}=\mathrm{OEt}(\mathbf{5 1 a}), \mathrm{Ph}(\mathbf{5 1 b}))$, were prepared in one-step by reacting 
$\mathrm{RuCl}_{3} \cdot 3 \mathrm{H}_{2} \mathrm{O}$ with $\mathrm{P}(\mathrm{OEt})_{3}$ and $\mathrm{PPh}(\mathrm{OEt})_{2}$, respectively, in refluxing ethanol and in the presence of commercial Diazald ( $N$-methyl- $N$-nitroso- $p$-toluenesulfonamide) as the nitrosyl ligand source (Scheme 14) [57].

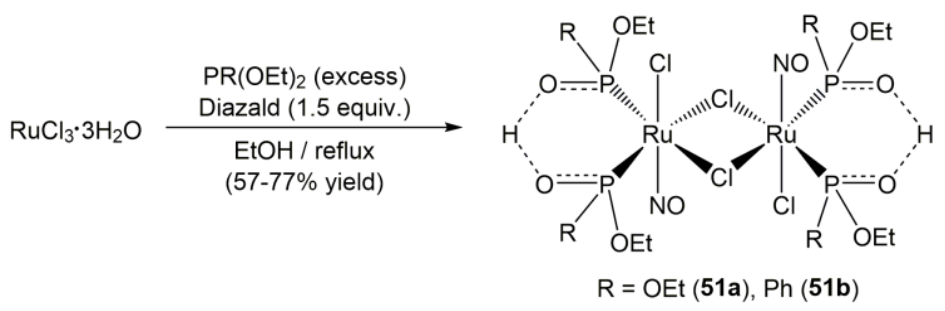

Scheme 14. Synthesis of the dinuclear nitrosyl-ruthenium(II) complexes 51a-b.

Although not in a selective manner, the formation of the cyclopentadienylruthenium(II) derivative $\left[\mathrm{RuCp}\left\{\kappa^{5}-(P, C, C, C, C)-\mathrm{P}\left(\mathrm{OCH}_{2} \mathrm{CH}=\mathrm{CH}_{2}\right)_{2}(\mathrm{OH})\right\}\right]\left[\mathrm{PF}_{6}\right] \quad(\mathrm{see}$ Figure 8 ), upon treatment of $\left[\mathrm{RuCp}(\mathrm{NCMe})_{3}\right]\left[\mathrm{PF}_{6}\right]$ with tris(allyloxy)phosphine $\mathrm{P}\left(\mathrm{OCH}_{2} \mathrm{CH}=\mathrm{CH}_{2}\right)_{3}$ at room temperature, was described by the group of Nelson [58]. This compound results from the hydrolysis of one of the allyloxy groups in the corresponding complex $\quad\left[\mathrm{RuCp}\left\{\kappa^{5}-(P, C, C, C, C)-\mathrm{P}\left(\mathrm{OCH}_{2} \mathrm{CH}=\mathrm{CH}_{2}\right)_{3}\right\}\right]\left[\mathrm{PF}_{6}\right] \quad$ by adventitious water present in the acetonitrile solvent employed. The latter, along with $\left.\left[\mathrm{RuCp}\left\{\kappa^{5}-(P, C, C, C, C)-\mathrm{P}(=\mathrm{O}) \mathrm{CH}_{2} \mathrm{CH}=\mathrm{CH}_{2}\right)_{2}\right\}\right], \quad\left[\mathrm{RuCp}(\right.$ allyl $\left.)(\mathrm{NCMe})_{2}\right]$ and the Arbuzov rearrangement product $\mathrm{P}(=\mathrm{O})\left(\mathrm{CH}_{2} \mathrm{CH}=\mathrm{CH}_{2}\right)\left(\mathrm{OCH}_{2} \mathrm{CH}=\mathrm{CH}_{2}\right)_{2}$, were also isolated in the reaction, with the ratio of the five compounds being dependent on the stoichiometry employed.

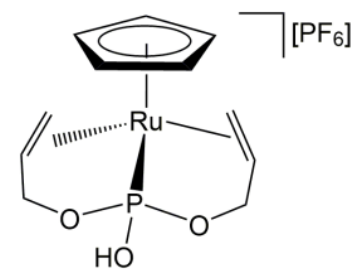

Figure 8. Structure of complex $\left[\mathrm{RuCp}\left\{\kappa^{5}-(P, C, C, C, C)-\mathrm{P}\left(\mathrm{OCH}_{2} \mathrm{CH}=\mathrm{CH}_{2}\right)_{2}(\mathrm{OH})\right\}\right]\left[\mathrm{PF}_{6}\right]$. 
A P-O bond hydrolysis process was observed by Milstein and co-workers in the reaction of the PONOP pincer $\mathrm{Ru}(0)$ complexes $\mathbf{5 2}$ with water, from which the zwitterionic hydride-ruthenium(II) derivatives $\mathbf{5 3}$ could be isolated (Scheme 15) [59]. Formation of $\mathbf{5 3}$ most probably involves the initial protonation of the ruthenium atom by water and subsequent attack of the $\mathrm{OH}^{-}$ion liberated in the process to one of the P-O bonds of the pincer diphosphinite ligand, thus leading to its cleavage.

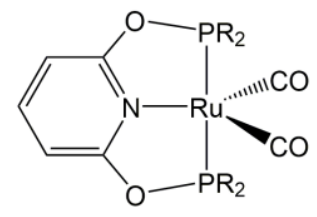

52

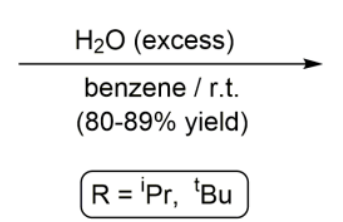

$\mathrm{R}={ }^{\mathrm{i}} \mathrm{Pr},{ }^{\mathrm{t}} \mathrm{Bu}$

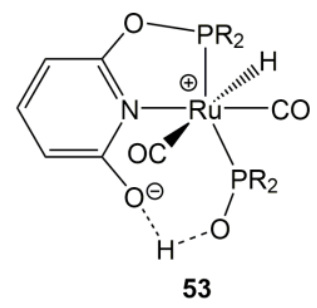

53

Scheme 15. Hydrolysis of the P-O bond of pincer phosphinite ligands coordinated to $\mathrm{Ru}(0)$.

In the context of their studies on the generation, control and induction of chirality in ruthenium(II)-bis(bipyridine) compounds, Inoue and co-workers reported on the thermal reactivity of cis-[RuCl 2 (bipy $\left.)_{2}\right]$ towards $\mathrm{PPh}(\mathrm{OEt})_{2}$ in an ethanol/water mixture. The reaction led to the formation of a separable mixture of $\left[\mathrm{RuCl}(\text { bipy })_{2}\left\{\mathrm{PPh}(\mathrm{OEt})_{2}\right\}\right][\mathrm{Cl}]$ and two diastereoisomers (in racemic form) of the hydrolyzed product $\left[\mathrm{RuCl}(\text { bipy })_{2}\{\mathrm{PPh}(\mathrm{OEt})(\mathrm{OH})\}\right][\mathrm{Cl}]$, in which the phosphorus atom presents a $R$ or $S$ configuration and the metal center a $\Lambda$ or $\Delta$ disposition (54a and 54b in Figure 9) [60]. Remarkably, upon irradiation of 54a at the LC band (295-305 nm) it evolved into its atropisomer 54c, whose structure could be determined by X-ray diffraction, featuring the same configuration for the phosphorus and ruthenium atoms, and differing from 54a in the different orientation adopted by the $\mathrm{PPh}(\mathrm{OEt})(\mathrm{OH})$ ligand. 

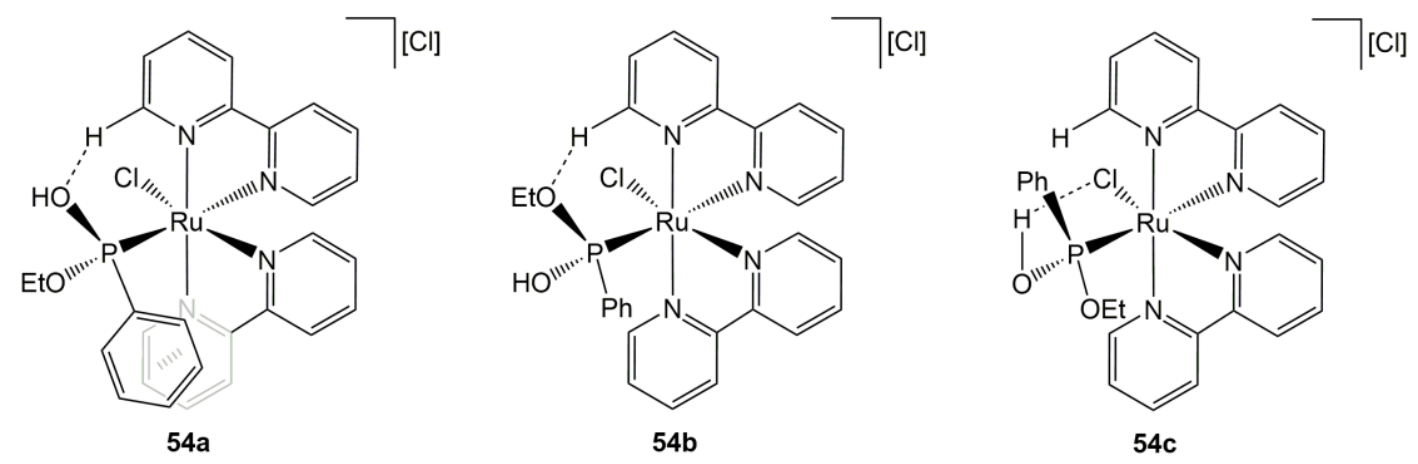

Figure 9. The three isomers of complex $\left[\mathrm{RuCl}(\text { bipy })_{2}\{\mathrm{PPh}(\mathrm{OEt})(\mathrm{OH})\}\right][\mathrm{Cl}]$ (only the $\Delta$ enantioner is represented in each case).

During attempts to crystallize the octahedral ruthenium(II) derivative $\left[\mathrm{RuCl}_{2}\left\{\kappa^{2}-\right.\right.$ $\left.\left.P, O-\mathrm{Ph}_{2} \mathrm{POC}(=\mathrm{O}) \mathrm{Et}\right\}_{2}\right]$ (56), generated by reaction of $\left[\mathrm{RuCl}_{2}\left(\mathrm{PPh}_{3}\right)_{3}\right]$ with two equivalents of the mixed anhydride ligand $\mathrm{Ph}_{2} \mathrm{POC}(=\mathrm{O}) \mathrm{Et}(\mathbf{5 5})$, crystals of the dimeric chloride-bridged complex 57 were obtained by Cole-Hamilton and co-workers (Scheme 16) [61]. Formation of $\mathbf{5 7}$ involves the hydrolysis of the P-O bond in one of the two Pdonor ligands present in $\mathbf{5 6}$, due probably to the presence of traces of water in the solvents employed for the crystallization process $\left(\mathrm{CH}_{2} \mathrm{Cl}_{2}\right.$ and pentane).
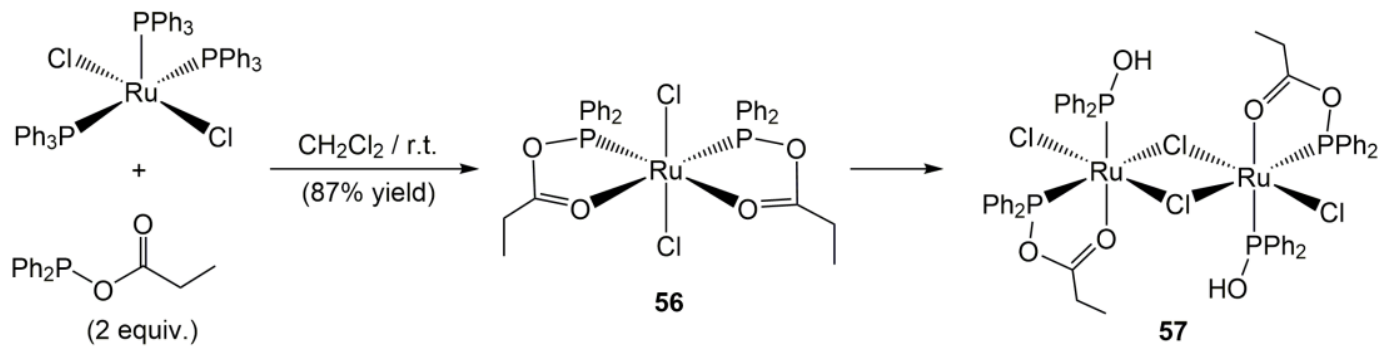

55

Scheme 16. Synthesis of complex $\mathbf{5 6}$ and structure of its hydrolyzed product 57.

On the other hand, Jagirdar and co-workers found that the trimethylphosphite ligand in the hydride ruthenium(II) complex trans-[RuH(dppe $\left.)_{2}\left\{\mathrm{P}(\mathrm{OMe})_{3}\right\}\right][\mathrm{OTf}](\mathbf{5 8})$ undergoes facile dealkylation processes upon treatment with wet triflic acid. Thus, the 
reaction of $\mathbf{5 8}$ with 3 equivalents of HOTf, in dicloromethane at room temperature and under an atmosphere of $\mathrm{H}_{2}$, led to a mixture of three different dihydrogen complexes namely trans-[Ru(dppe $\left.)_{2}\left(\eta^{2}-\mathrm{H}_{2}\right)\left\{\mathrm{P}(\mathrm{OMe})_{3-\mathrm{x}}(\mathrm{OH})_{\mathrm{x}}\right\}\right][\mathrm{OTf}]_{2}(\mathrm{x}=0(\mathbf{5 9}), 1(\mathbf{6 0}), 2(\mathbf{6 1}))$ (Scheme 17) [62]. All these species are unstable and lose the bound $\mathrm{H}_{2}$ ligand to afford highly electrophilic 16-electron compounds of general composition $\left[\mathrm{Ru}(\mathrm{dppe})_{2}\left\{\mathrm{P}(\mathrm{OMe})_{3-\mathrm{x}}(\mathrm{OH})_{\mathrm{x}}\right\}\right][\mathrm{OTf}]_{2}$. From this reaction mixture, complex $\left[\mathrm{Ru}(\mathrm{dppe})_{2}\left\{\mathrm{P}(\mathrm{OMe})(\mathrm{OH})_{2}\right\}\right][\mathrm{OTf}]_{2}$ (62) could be isolated in $79 \%$ yield and fully characterized by X-ray crystallography (Scheme 17). As expected, complex 62 readily reacts with two-electron donor ligands, such as carbon monoxide and acetonitrile, under mild conditions to afford the corresponding saturated 18-electron derivatives trans$\left[\mathrm{RuL}(\mathrm{dppe})_{2}\left\{\mathrm{P}(\mathrm{OMe})(\mathrm{OH})_{2}\right\}\right][\mathrm{OTf}]_{2}(\mathrm{~L}=\mathrm{CO}(\mathbf{6 3 a}), \mathrm{NCMe}(\mathbf{6 3 b}))$ in excellent yields (Scheme 17) [63].
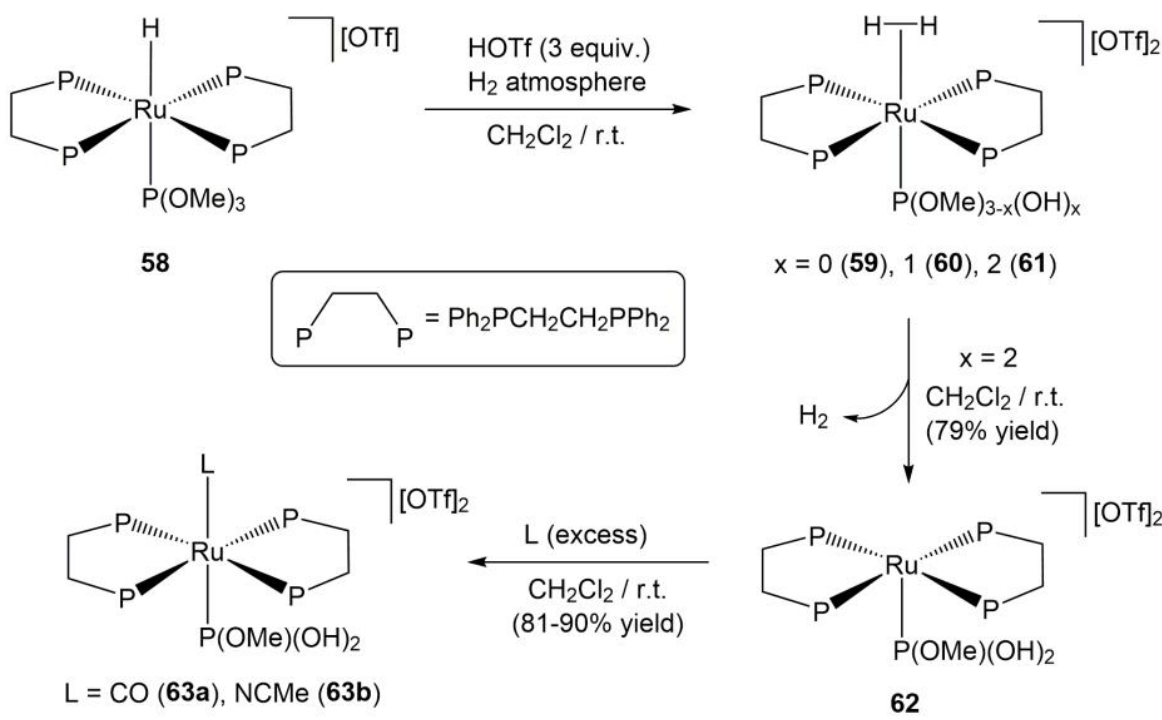

$x=0(59), 1(60), 2(61)$
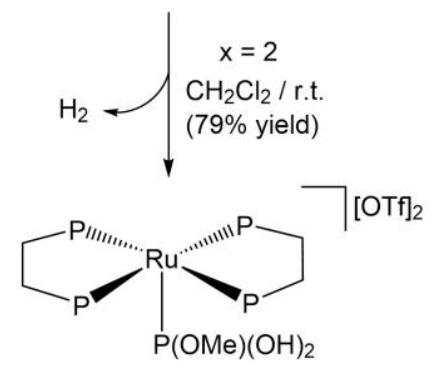

62

Scheme 17. Dealkylation reactions of a ruthenium-coordinated trimethylphosphite ligand.

The coordinatively unsaturated complex $\left[\mathrm{Ru}(\mathrm{dppe})_{2}\left\{\mathrm{P}(\mathrm{OMe})(\mathrm{OH})_{2}\right\}\right][\mathrm{OTf}]_{2}(\mathbf{6 2})$ also reacts with $\mathrm{H}_{2}$ and $\mathrm{EtMe}_{2} \mathrm{SiH}$ leading to the heterolytic splitting of the $\mathrm{H}-\mathrm{H}$ and $\mathrm{H}$ - 
$\mathrm{Si}$ bonds of these reagents. In these reactions, mixtures of products, including among others trans-[RuH(dppe $\left.)_{2}\left\{\mathrm{P}(\mathrm{OMe})(\mathrm{OH})_{2}\right\}\right][\mathrm{OTf}]$, trans-[RuH(dppe $\left.)_{2}\left(\eta^{2}-\mathrm{H}_{2}\right)\right][\mathrm{OTf}]$ and $\left[\mathrm{Ru}(\mathrm{dppe})_{2}\left\{\mathrm{P}(\mathrm{OH})_{3}\right\}\right][\mathrm{OTf}]_{2}(\mathbf{6 4})$, are generated [63]. Interestingly, performing the reaction of 62 with $\mathrm{H}_{2}$ at low temperature, the coordinatively unsaturated phosphorous acid complex $\left[\mathrm{Ru}(\mathrm{dppe})_{2}\left\{\mathrm{P}(\mathrm{OH})_{3}\right\}\right][\mathrm{OTf}]_{2}(\mathbf{6 4})$ could be isolated in $70 \%$ yield and its structure unambiguously confirmed by X-ray crystallography (Scheme 18). In addition, the potential of $\mathbf{6 2}$ for the activation of $\mathrm{C}-\mathrm{H}$ bonds was also explored. In particular, treatment of a dichloromethane solution of $\mathbf{6 2}$ with phenylacetylene under refluxing conditions resulted in the heterolysis of the $\mathrm{C}-\mathrm{H}$ bond of the alkyne and formation the saturated alkynyl complex trans $-\left[\mathrm{Ru}(\mathrm{C} \equiv \mathrm{CPh})(\mathrm{dppe})_{2}\left\{\mathrm{P}(\mathrm{OMe})(\mathrm{OH})_{2}\right\}\right][\mathrm{OTf}]$ and triflic acid [64]. Further hydrogenation of this phenylacetylide-Ru(II) complex afforded the hydride derivative trans $-\left[\mathrm{RuH}(\mathrm{dppe})_{2}\left\{\mathrm{P}(\mathrm{OMe})(\mathrm{OH})_{2}\right\}\right][\mathrm{OTf}]$ and $\mathrm{PhC} \equiv \mathrm{CH}$, via addition of $\mathrm{H}_{2}$ across the $\mathrm{Ru}-\mathrm{C}$ bond. The related chloride complex trans$\left[\mathrm{RuCl}(\mathrm{dppe})_{2}\left\{\mathrm{P}(\mathrm{OMe})(\mathrm{OH})_{2}\right\}\right][\mathrm{OTf}]$ could also be isolated in high yield by reacting $\left[\mathrm{Ru}(\mathrm{dppe})_{2}\left\{\mathrm{P}(\mathrm{OMe})(\mathrm{OH})_{2}\right\}\right][\mathrm{OTf}]_{2}(62)$ with $\mathrm{HSiCl}_{3}[64]$.

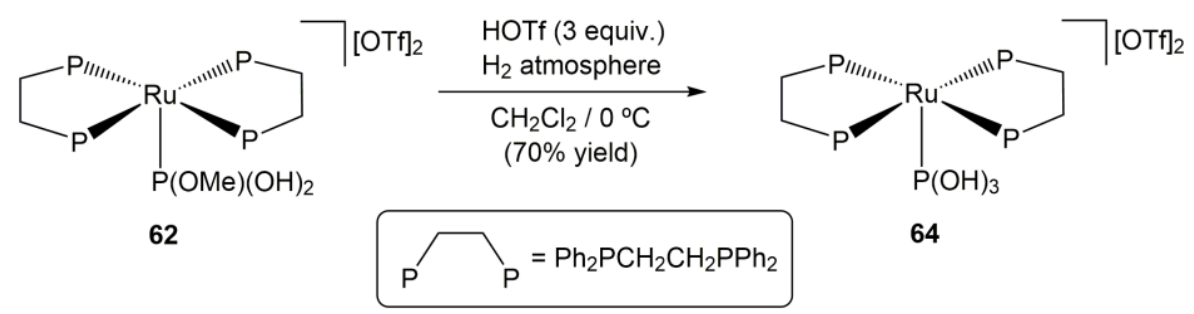

Scheme 18. Access to the phosphorous acid-ruthenium(II) complex 64.

Concerning the reactivity of the 16-electron phosphorous acid complex $\left[\mathrm{Ru}(\mathrm{dppe})_{2}\left\{\mathrm{P}(\mathrm{OH})_{3}\right\}\right][\mathrm{OTf}]_{2}(\mathbf{6 4})$, it readily reacts with $N$-benzylideneaniline to afford the phosphonate derivative $\left[\mathrm{Ru}(\mathrm{dppe})_{2}\left\{\mathrm{P}(=\mathrm{O})(\mathrm{OH})_{2}\right\}\right][\mathrm{OTf}]$ by deprotonation of the $\mathrm{P}(\mathrm{OH})_{3}$ ligand [64]. In addition, it was also able to activate in a heterolytic fashion the 
$\mathrm{H}-\mathrm{H}, \mathrm{Si}-\mathrm{H}$ and $\mathrm{B}-\mathrm{H}$ bonds in $\mathrm{H}_{2}(\mathrm{~g})$, EtMe $2 \mathrm{SiH}$ and $\mathrm{Et}_{3} \mathrm{SiH}$, and $\mathrm{H}_{3} \mathrm{~B} \cdot \mathrm{PR}_{3}(\mathrm{R}=\mathrm{Me}, \mathrm{Ph})$, respectively, to generate as a common product the hydride complex trans$\left[\mathrm{RuH}(\mathrm{dppe})_{2}\left\{\mathrm{P}(\mathrm{OH})_{3}\right\}\right][\mathrm{OTf}]$ (in the reaction with $\mathrm{H}_{2(\mathrm{~g})}$ minor amounts of trans$\left[\mathrm{RuH}(\mathrm{dppe})_{2}\left(\eta^{2}-\mathrm{H}_{2}\right)\right][\mathrm{OTf}]$ were also formed by the partial substitution of the $\mathrm{P}(\mathrm{OH})_{3}$ ligand with $\mathrm{H}_{2}$ ) [65].

Hydrolysis of the complexed $\mathrm{R}_{2} \mathrm{P}-\mathrm{OC}(=\mathrm{O}) \mathrm{Me}\left(\mathrm{R}={ }^{\mathrm{i}} \mathrm{Pr}, \mathrm{Cy}\right)$ ligands, by means of wet triflic acid, in the cyclometalated compounds 65a-b was reported by Pregosin and co-workers (Scheme 19) [66]. The reactions led to the formation of the tethered $\left(\eta^{6}-\right.$ arene)-ruthenium(II) complexes $\mathbf{6 6 a - b}$ resulting from the cleavage of both the P-O and $\mathrm{Ru}-\mathrm{C}$ bonds of $\mathbf{6 6 a - b}$, and concomitant $\eta^{6}$-coordination of one of the aromatic rings of the binaphthyl skeleton to ruthenium. When dissolved in methanol, 66a was found to evolve into the corresponding hydride complex 67a, via initial displacement of the triflate ligand by a methoxide group which in turn is converted into the hydride through a $\beta$-hydride elimination process.

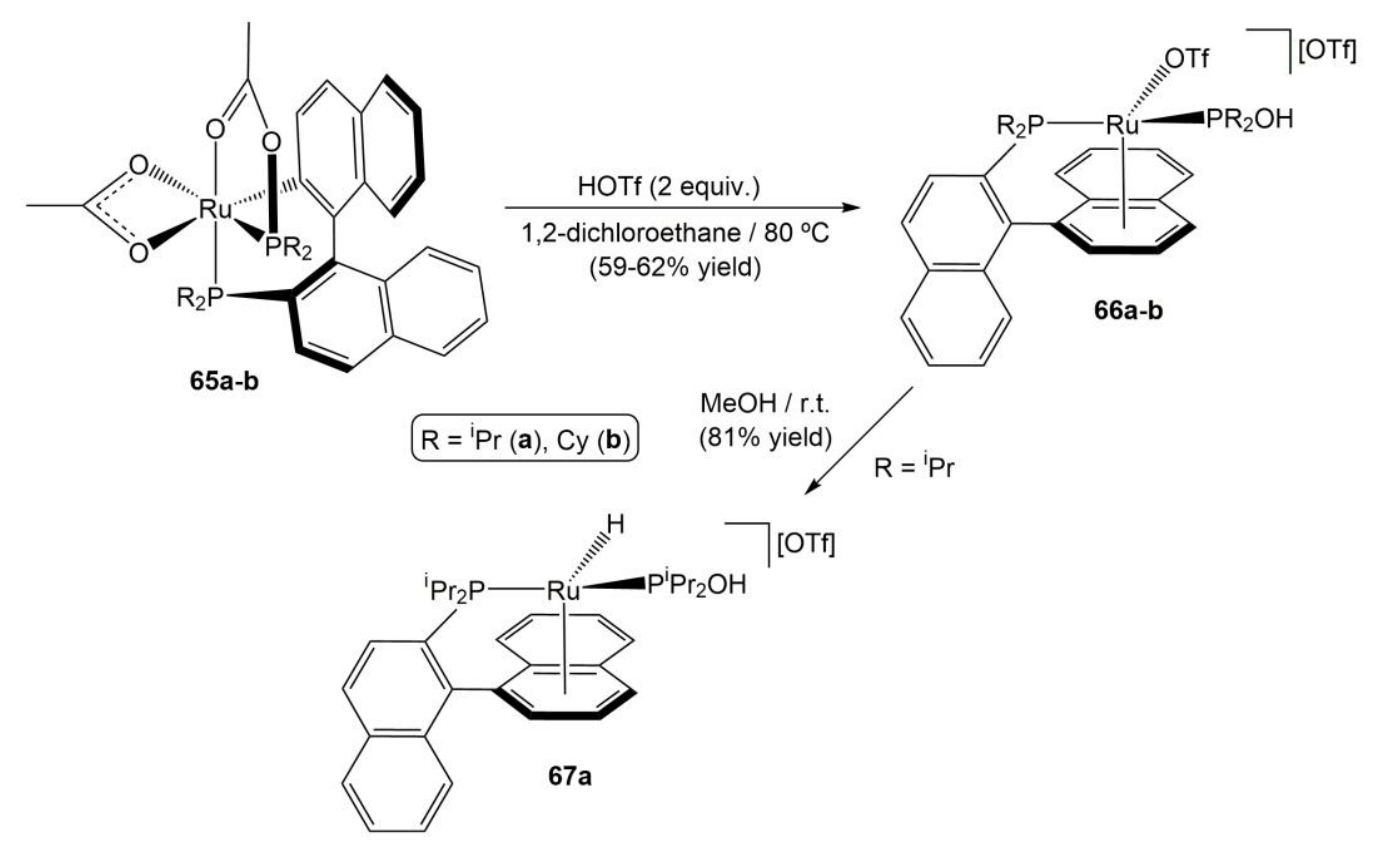

Scheme 19. Synthesis of the tethered ( $\eta^{6}$-arene)-ruthenium(II) complexes 66a-b. 
On another vein, Ros and co-workers described the facile hydrolysis of the P-N bond of $\mathrm{PPh}_{2}\left(\mathrm{Me}_{2} \mathrm{Pz}\right)$ (1-(3,5-dimethyl)pyrazolyldiphenylphosphine) when coordinated to the $\left[\mathrm{RuCl}_{2}\left(\eta^{6}-p\right.\right.$-cymene)] fragment (Scheme 20) [67]. Thus, addition at room temperature of 1 equivalent of water to a dichloromethane solution of $\left[\mathrm{RuCl}_{2}\left(\eta^{6}-p\right.\right.$ cymene) $\left.\left\{\mathrm{PPh}_{2}\left(\mathrm{Me}_{2} \mathrm{Pz}\right)\right\}\right]$ (68) resulted in the rapid formation of the cationic complex $\left[\mathrm{RuCl}\left(\eta^{6}-p\right.\right.$-cymene $\left.)\left(\mathrm{Me}_{2} \mathrm{PzH}\right)\left(\mathrm{PPh}_{2} \mathrm{OH}\right)\right][\mathrm{Cl}] \quad(69), \quad$ which contain both 3,5dimethylpyrazole and diphenylphosphinous acid coordinated molecules. X-Ray diffraction analysis of $\mathbf{6 9}$ indicated that, in the solid state, the chloride counteranion interacts through $\mathrm{H}$-bonding with the $\mathrm{N}-\mathrm{H}$ and $\mathrm{O}-\mathrm{H}$ groups of these molecules as depicted in Scheme 20. Remarkably, the behavior of complex 68 contrasts with that shown by the related iron(II) derivative $\left[\mathrm{FeCp}(\mathrm{CO})_{2}\left\{\mathrm{PPh}_{2}\left(\mathrm{Me}_{2} \mathrm{Pz}\right)\right\}\right][\mathrm{BF} 4]$, which does not react with water even under refluxing conditions [68]. The higher reactivity of the pyrazolylphosphine ligand in $\mathbf{6 8}$ is associated with the more basic character of the lone pair on the pyrazole $\mathrm{N} 2$ atom due to its coordination to a less electrophilic ruthenium center.

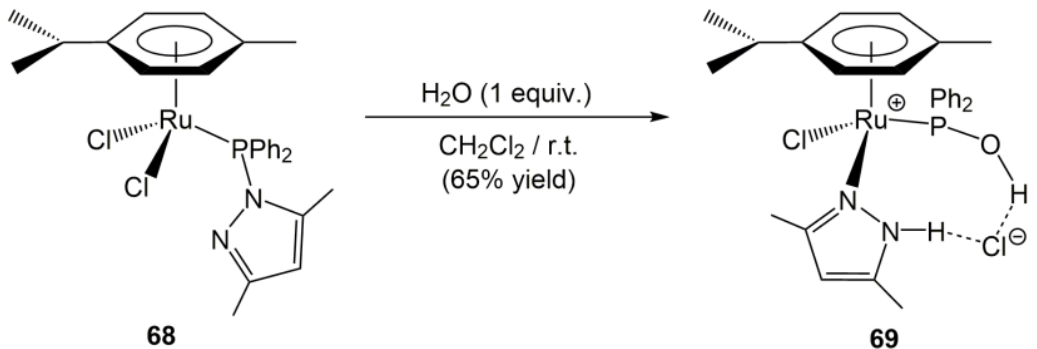

Scheme 20. Hydrolysis of a pyrazolylphosphine in the coordination sphere of ruthenium.

Related hydrolytic P-N bond cleavage reactions were observed when dichloromethane solutions of the cyclic azaphosphacarbene-Ru(II) complexes 70a,b 
were treated with water at room temperature (Scheme 21) [69]. Interestingly, chromatographic work-up over $\mathrm{Al}_{2} \mathrm{O}_{3}$ of one of the resulting products, i.e. compound 71a, led to the deprotonation of the diphenylphosphinous acid ligand and generation of complex 72 in which, according to single-crystal X-ray diffraction data, the oxygen atom of the $\mathrm{Ph}_{2} \mathrm{PO}^{-}$anion establishes strong intramolecular $\mathrm{H}$-bonds with the $\mathrm{N}-\mathrm{H}$ units of the aminophosphine and aminocarbene ligands. This deprotonation process was found to be reversible, complex 71a being quantitatively regenerated when $\mathbf{7 2}$ was exposed to acids. Also of note is the fact that, attempts to crystallize $\mathbf{7 1 b}$ by diffusion of diethyl ether into a saturated $\mathrm{CH}_{2} \mathrm{Cl}_{2}$ solution of this complex, afforded instead crystals of $\mathbf{7 3}$ with concomitant aniline elimination. This compound represents a rare example of a transition metal complex featuring the chelating $\mathrm{Ph}_{2} \mathrm{P}-\mathrm{O}-\mathrm{PPh}_{2}$ ligand.
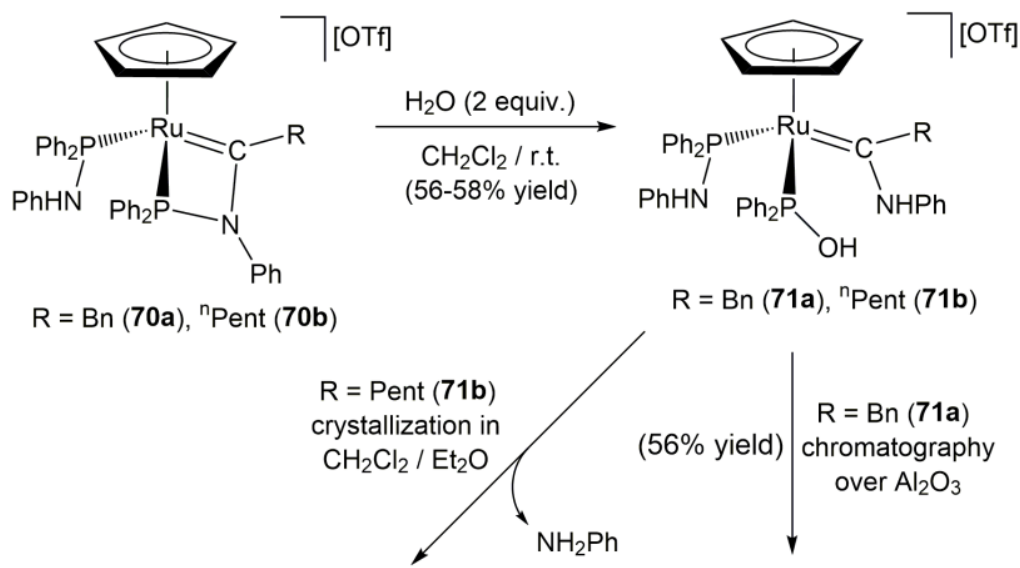

$\mathrm{R}=\mathrm{Bn}(\mathbf{7 1 a}),{ }^{\mathrm{n}} \mathrm{Pent}(\mathbf{7 1 b})$

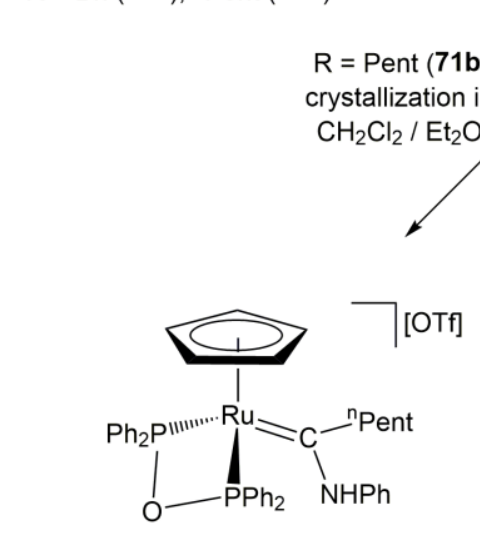

73

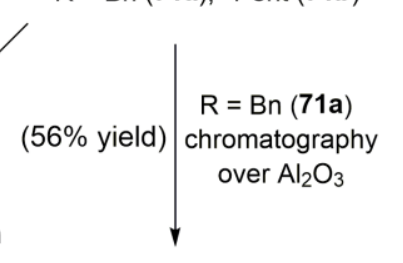

Scheme 21. Synthesis and behavior of the phosphinous acid complexes 71a,b. 
The generation of phosphinous acid-ruthenium(II) complexes by hydrolysis of coordinated chlorophosphines has also been quoted in the literature. In particular, experiments carried out in NMR tubes with $\mathrm{CD}_{2} \mathrm{Cl}_{2}$ solutions of several areneruthenium(II) complexes of general composition $\left[\mathrm{RuCl}_{2}\left(\eta^{6}-p\right.\right.$-cymene $\left.)\left(\mathrm{PR}_{2} \mathrm{Cl}\right)\right](\mathrm{R}=$ aliphatic, aromatic or heteroaromatic group; 74b-l) showed that, upon addition of one drop of water, they cleanly evolve into $\left[\mathrm{RuCl}_{2}\left(\eta^{6}-p\right.\right.$-cymene $\left.)\left(\mathrm{PR}_{2} \mathrm{OH}\right)\right](\mathbf{2 0 b}-\mathbf{l})(\mathrm{Scheme}$ 22) [32]. As expected, the P-Cl bond hydrolysis in $\mathbf{7 4 b - l}$ was found to proceed faster with those compounds containing aromatic chlorophosphines substituted with electronwithdrawing groups (74g and $\mathbf{7 4 h}$ ), since the nucleophilic attack of water is in these cases favored by the lower electron density on the phosphorus atom. In this context, we must also indicate that complex $\left[\mathrm{RuCl}_{2}\left(\eta^{6}-p\right.\right.$-cymene $\left.)\left(\mathrm{PPh}_{2} \mathrm{OH}\right)\right](\mathbf{2 0 f})$ was isolated in 85\% yield by Pandiakumar and Samuelson when performing the reaction of dimer $\left[\left\{\mathrm{RuCl}(\mu-\mathrm{Cl})\left(\eta^{6}-p \text {-cymene }\right)\right\}_{2}\right](\mathbf{1 8 b})$ with $\mathrm{PPh}_{2} \mathrm{Cl}$ in refluxing $\mathrm{THF}$, due to the adventitious hydrolysis of the initially formed chlorophosphine complex $\left[\mathrm{RuCl}_{2}\left(\eta^{6}-p\right.\right.$ cymene $\left.)\left(\mathrm{PPh}_{2} \mathrm{Cl}\right)\right]$ (74f) [70].

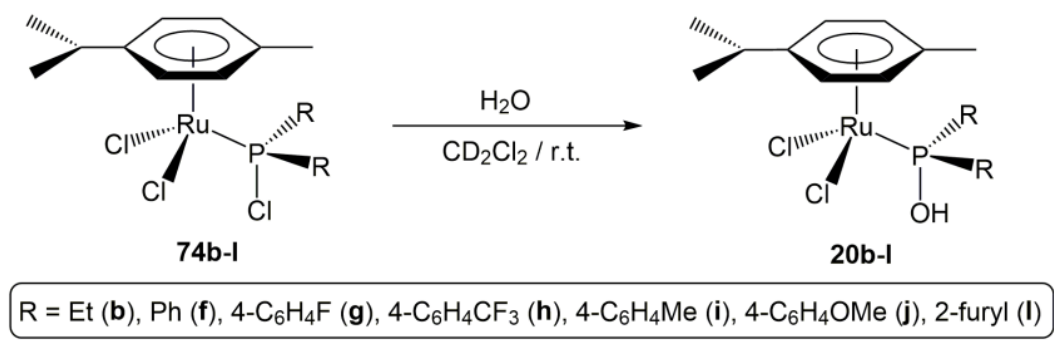

Scheme 22. Generation of the phosphinous acid complexes $20 \mathrm{~b}-1$ by hydrolysis of $\mathbf{7 4 b}-\mathbf{l}$.

While studying the reactivity of the dimethyldithiophosphinate-Ru(II) complex cis-[Ru( $\left.\left(\mathrm{S}_{2} \mathrm{PMe}_{2}\right)_{2}\left(\mathrm{PPh}_{3}\right)_{2}\right]$ towards $P$-donor ligands, Robertson and Stephenson found that its treatment with a large excess of $\mathrm{PPh}_{2} \mathrm{Cl}$, in a refluxing mixture of acetone and 
water, results in the formation of a crystalline solid for which structure $\mathbf{7 5}$ was proposed (Figure 10) [71]. When the same reaction was performed with a lower amount of $\mathrm{PPh}_{2} \mathrm{Cl}$ in aqueous methanol a mixture of compounds $\mathbf{7 5}$ and $\mathbf{7 6}$ was obtained, the latter being an intermediate in the formation of 75 . In these reactions, the removal of one dimethyldithiophosphinate ligands in the starting material cis- $\left[\mathrm{Ru}\left(\mathrm{S}_{2} \mathrm{PMe}_{2}\right)_{2}\left(\mathrm{PPh}_{3}\right)_{2}\right]$ was believed to proceed by protonation with the $\mathrm{HCl}$ released during the hydrolysis of $\mathrm{PPh}_{2} \mathrm{Cl}$. In accord with this, compound cis- $\left[\mathrm{Ru}\left(\mathrm{S}_{2} \mathrm{PMe}_{2}\right)_{2}\left(\mathrm{PPh}_{3}\right)\left\{\mathrm{P}(\mathrm{OMe})_{2} \mathrm{OH}\right\}\right]$ (77), that keeps intact the two chelating $\mathrm{Me}_{2} \mathrm{PS}_{2}^{-}$ligands, was exclusively formed in the reaction of cis-[Ru( $\left.\left.\mathrm{S}_{2} \mathrm{PMe}_{2}\right)_{2}\left(\mathrm{PPh}_{3}\right)_{2}\right]$ with excess of $(\mathrm{MeO})_{2} \mathrm{P}(=\mathrm{O}) \mathrm{H}$ in methanol. On the other hand, treatment of 75 with $\mathrm{BF}_{3} \cdot \mathrm{Et}_{2} \mathrm{O}$ allowed also the isolation of the zwitterionic derivative $\left[\mathrm{Ru}\left(\mathrm{S}_{2} \mathrm{PMe}_{2}\right)\left\{\left(\mathrm{PPh}_{2} \mathrm{O}\right)_{3} \mathrm{BF}\right\}\right]$ (78). This compound was found to react with $\mathrm{VO}(\mathrm{acac})_{2}$ and $\mathrm{Co}(\mathrm{acac})_{2}$, generating the trimetallic species $\left[\mathrm{VO}\left\{\left(\mathrm{OPPh}_{2}\right)_{2}\left(\mathrm{HOPPh}_{2}\right) \mathrm{Ru}\left(\mathrm{S}_{2} \mathrm{PMe}_{2}\right)\right\}_{2}\right]$ and $\left[\mathrm{Co}\left\{\left(\mathrm{OPPh}_{2}\right)_{3} \mathrm{Ru}\left(\mathrm{S}_{2} \mathrm{PMe}_{2}\right)\right\}_{2}\right]$, respectively, in which the $\mathrm{Ph}_{2} \mathrm{PO}^{-}$anions act as bridging ligands.

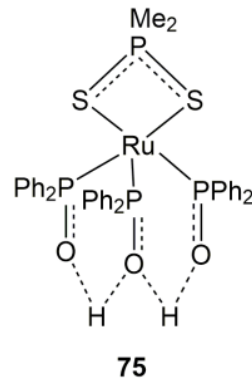

75

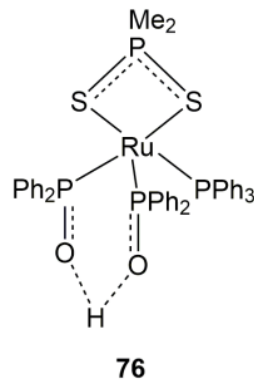

76

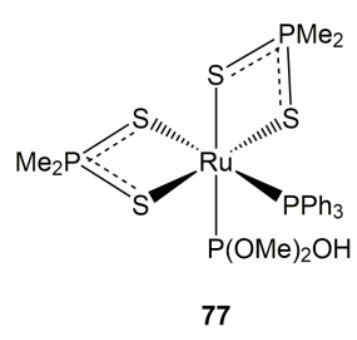

77

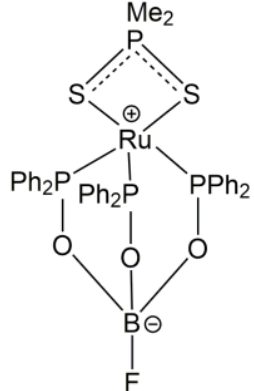

78

Figure 10. Structure of compounds 75-78

Hydrolysis reactions of white phosphorus $\left(\mathrm{P}_{4}\right)$ coordinated to ruthenium fragments represent an alternative route to generate $\mathrm{P}-\mathrm{OH}$ ligands, although the selectivity of the process is relatively low [17]. Thus, as observed for $\left[\mathrm{FeCp}(\mathrm{dppe})\left(\kappa^{1}-\mathrm{P}_{4}\right)\right]\left[\mathrm{PF}_{6}\right](\mathbf{1 1}$ in 
Figure 1) [15], its ruthenium counterpart $\left[\mathrm{RuCp}(\mathrm{dppe})\left(\kappa^{1}-\mathrm{P}_{4}\right)\right]\left[\mathrm{PF}_{6}\right]$ reacts with water, in THF or acetone solution at room temperature, to generate a mixture of products from which free phosphorous acid $\mathrm{H}_{3} \mathrm{PO}_{3}$, and complexes $\left[\mathrm{RuCp}(\mathrm{dppe})\left(\mathrm{PH}_{3}\right)\right]\left[\mathrm{PF}_{6}\right]$ and $\left[\mathrm{RuCp}(\mathrm{dppe})\left\{\mathrm{P}(\mathrm{OH})_{3}\right\}\right]\left[\mathrm{PF}_{6}\right]$ (42b in Scheme 8), could be unambiguously identified [39]. Formation of minor amounts of compounds [RuCp(TPPMS $\left.)_{2}\left\{\mathrm{PH}(\mathrm{OH})_{2}\right\}\right]\left[\mathrm{PF}_{6}\right]$ (41a) and $\left[\mathrm{RuCp}(\mathrm{TPPMS})_{2}\left\{\mathrm{P}(\mathrm{OH})_{3}\right\}\right]\left[\mathrm{PF}_{6}\right]($ 41b in Scheme 8) was also observed when a DMF solution of $\left[\mathrm{RuCp}(\mathrm{TPPMS})_{2}\left(\kappa^{1}-\mathrm{P}_{4}\right)\right]\left[\mathrm{PF}_{6}\right]$ was treated with 10 equivalents of $\mathrm{H}_{2} \mathrm{O}$ at $35^{\circ} \mathrm{C}$ [40]. Nonetheless, as in the precedent case, the major ruthenium complex generated in this reaction is that containing $\mathrm{PH}_{3}$ as ligand, i.e. compound $\left[\mathrm{RuCp}(\mathrm{TPPMS})_{2}\left(\mathrm{PH}_{3}\right)\right]\left[\mathrm{PF}_{6}\right]$. Similar observations were made starting from the bis(triphenylphosphine) derivative $\left[\mathrm{RuCp}\left(\mathrm{PPh}_{3}\right)_{2}\left(\kappa^{1}-\mathrm{P}_{4}\right)\right]\left[\mathrm{PF}_{6}\right][72]$.

In this context, much attention has also been paid to the hydrolytic behavior of the $\mathrm{P}_{4}$-bridged dinuclear complex $\left[\left\{\mathrm{RuCp}\left(\mathrm{PPh}_{3}\right)_{2}\right\}_{2}\left(\mu-\mathrm{P}_{4}\right)\right][\mathrm{OTf}]_{2}$ (79; see Figure 11) [7375]. The hydrolytic disproportionation of the $\mathrm{P}_{4}$ ligand in this compound, in THF solution at r.t., was found to be markedly dependent on the amount of water employed. Thus, in addition to $\left[\mathrm{RuCp}\left(\mathrm{PPh}_{3}\right)_{2}\left\{\mathrm{PH}(\mathrm{OH})_{2}\right\}\right][\mathrm{OTf}]$ (39a in Scheme 8), $\left[\mathrm{RuCp}\left(\mathrm{PPh}_{3}\right)_{2}\left\{\mathrm{P}(\mathrm{OH})_{3}\right\}\right][\mathrm{OTf}] \quad\left(39 \mathrm{~b}\right.$ in Scheme 8), $\left[\mathrm{RuCp}\left(\mathrm{PPh}_{3}\right)_{2}\left(\mathrm{PH}_{3}\right)\right][\mathrm{OTf}]$, $\left[\left\{\mathrm{RuCp}\left(\mathrm{PPh}_{3}\right)_{2}\right\}_{2}\left(\mu-\mathrm{P}_{2} \mathrm{H}_{4}\right)\right][\mathrm{OTf}]_{2}$ and free phosphorous acid $\mathrm{H}_{3} \mathrm{PO}_{3}$, from some reactions the dinuclear species 80-82 (Figure 11), all containing P-OH ligands bonded to ruthenium, could also be isolated and structurally characterized by single-crystal Xray diffraction. The generation of complexes 39a and 39b (see Scheme 8), along with $\left[\mathrm{RuCp}\left(\mathrm{PPh}_{3}\right)_{2}\left(\mathrm{PH}_{2} \mathrm{SH}\right)\right][\mathrm{OTf}], \mathrm{H}_{3} \mathrm{PO}_{3}$ and $\mathrm{H}_{3} \mathrm{PO}_{2}$, by hydrolysis of the bridging phosphorus sesquisulfide ligand of $\left[\left\{\mathrm{RuCp}\left(\mathrm{PPh}_{3}\right)_{2}\right\}_{2}\left(\mu-\mathrm{P}_{4} \mathrm{~S}_{3}\right)\right][\mathrm{OTf}]_{2}(\mathbf{8 3}$ in Figure 11) has also been reported [73], as well as the reactivity of $\left[\left\{\mathrm{RuCp}\left(\mathrm{PMe}_{3}\right)_{2}\right\}_{2}\left(\mu-\mathrm{P}_{4}\right)\right][\mathrm{OTf}]_{2}$ towards water [41]. Mixtures of products, including $\left[\mathrm{RuCp}\left(\mathrm{PMe}_{3}\right)_{2}\left\{\mathrm{PH}(\mathrm{OH})_{2}\right\}\right][\mathrm{OTf}]$ 
(40a) and $\left[\mathrm{RuCp}\left(\mathrm{PMe}_{3}\right)_{2}\left\{\mathrm{P}(\mathrm{OH})_{3}\right\}\right][\mathrm{OTf}]$ (40b in Scheme 8), were again observed in the latter case.
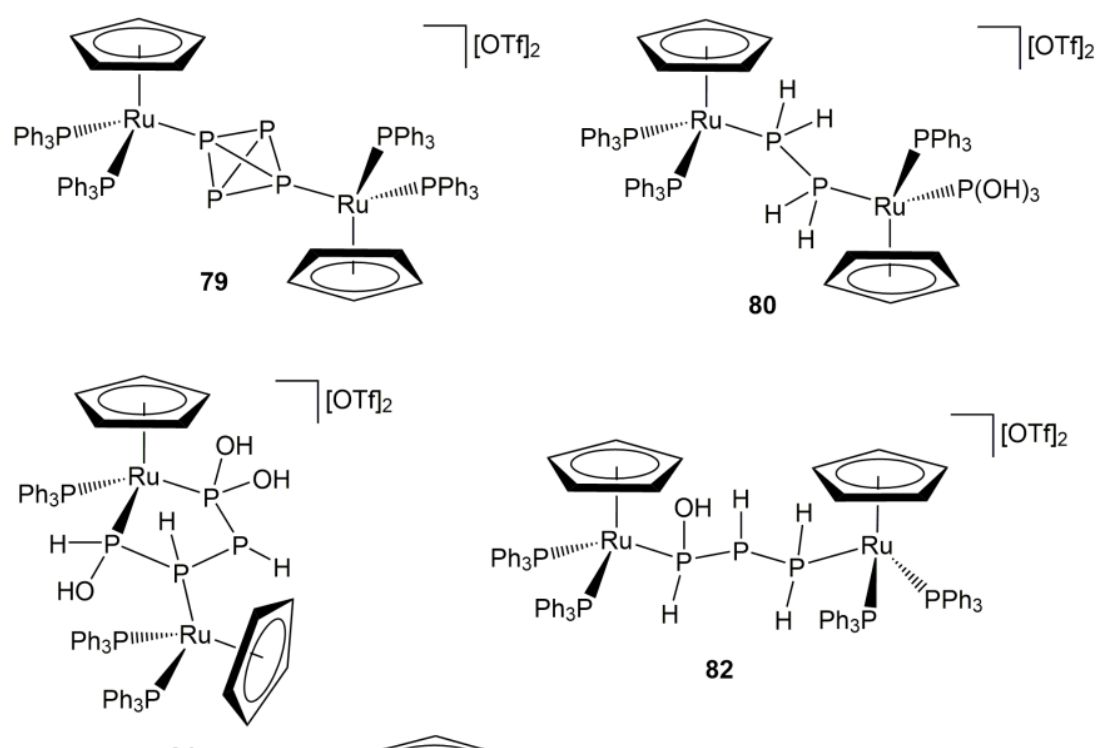

82

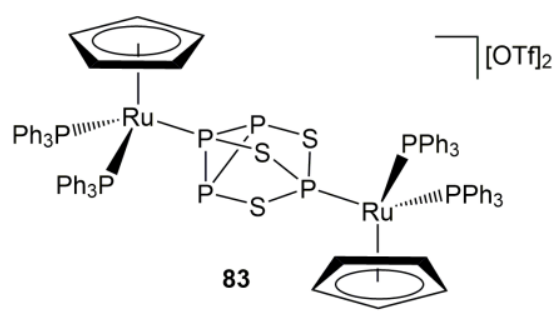

Figure 11. Structure of the dinuclear cyclopentadienyl-ruthenium(II) complexes 79-83.

Concerning the generation of Ru-P-OH complexes by hydrolysis of phosphoruscarbon bonds, a seminal contribution was made by Pregosin and co-workers in 2000 [76]. They reported the synthesis of the tethered ( $\eta^{6}$-arene)-ruthenium(II) complexes 86 and 87, containing diphenylphosphinous acid as ligand, using the Binap- and MeOBiphep-ruthenium diacetate derivatives $\mathbf{8 4}$ and $\mathbf{8 5}$, respectively, as starting materials (Scheme 23). Thus, the treatment of $\mathbf{8 4 - 8 5}$ with wet triflic acid in 1,2-dichloroethane under thermal conditions, results in the clean formation of 86-87 via cleavage of one of the P-C bonds of the atropisomeric diphosphines. Although mechanistic details were not given by the authors, the analogy between 86 and compounds 66a-b (see Scheme 19) 
may indicate that intermediate species related to $\mathbf{6 5 a - b}$ are probably involved in these reactions.
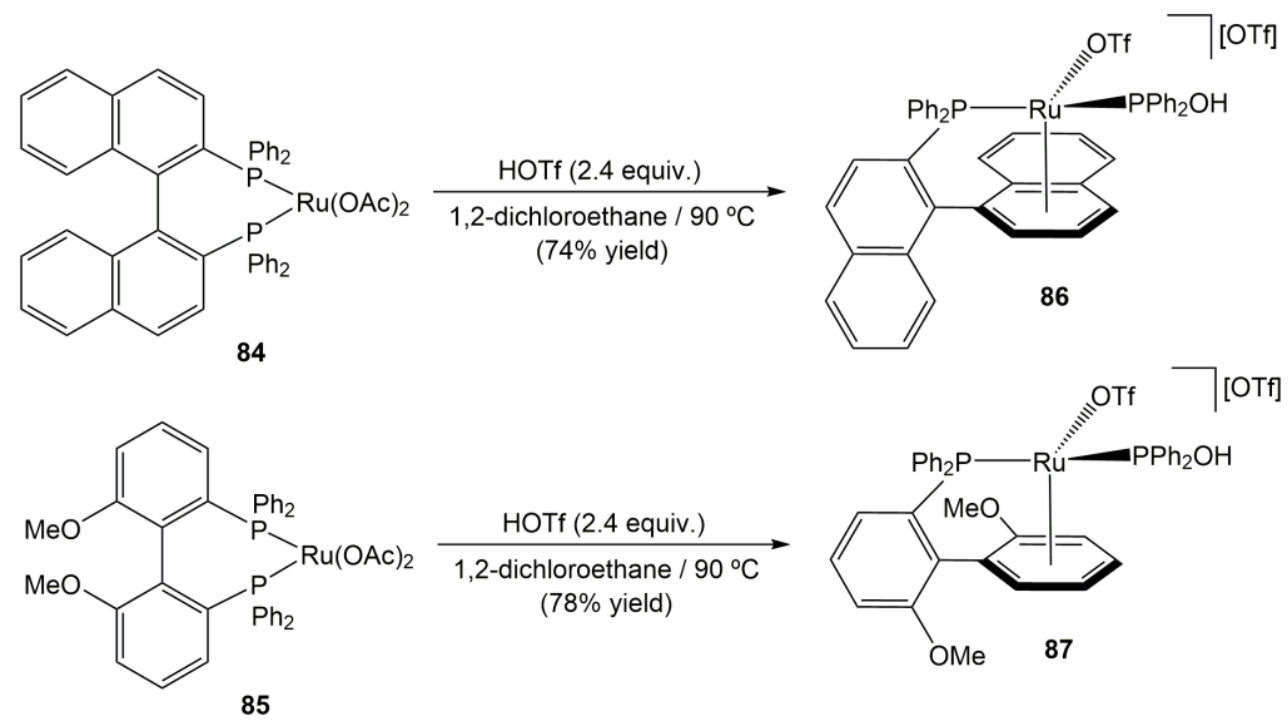

Scheme 23. Synthesis of the tethered ( $\eta^{6}$-arene)-ruthenium(II) complexes $\mathbf{8 6}$ and $\mathbf{8 7}$.

A similar P-C bond cleavage process was also observed when a dichloromethane solution of the Binap-Ru(II) precursor 84 was treated sequentially with 1 equiv. of the Brookhart's acid $\quad$ HBArF.2OEt $2 \quad\left(\mathrm{BArF}_{2} \quad=\quad\right.$ tetrakis[3,5bis(trifluoromethyl)phenyl]borate) and water, the reaction leading in this case to the quantitative formation of complex $\mathbf{8 8}$ (Figure 12) [77].

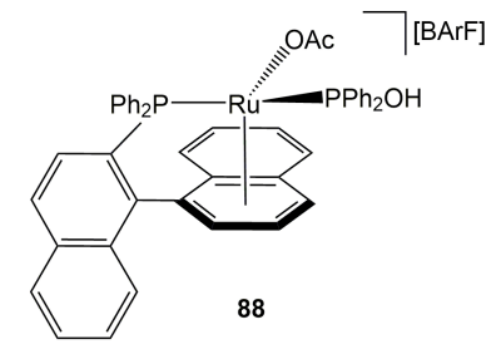

Figure 12. Structure of the tethered ( $\eta^{6}$-arene)-ruthenium(II) complex $\mathbf{8 8}$. 
The chemistry of complexes 86-88 was explored in deep by Pregosin and coworkers, showing some remarkable reactivity patterns [78]. For example, 86 readily reacts with simple alcohols, such as methanol, ethanol, 2-propanol or ethylene glycol, under neat conditions to generate complexes 89a-d (Scheme 24) [79,80]. These compounds result from the solvolytic and stereospecific cleavage of one of the P-C bonds of the $\mathrm{PPh}_{2} \mathrm{OH}$ ligand and concomitant migration of the phenyl group to ruthenium, with one molecule of triflic acid being eliminated during the process.

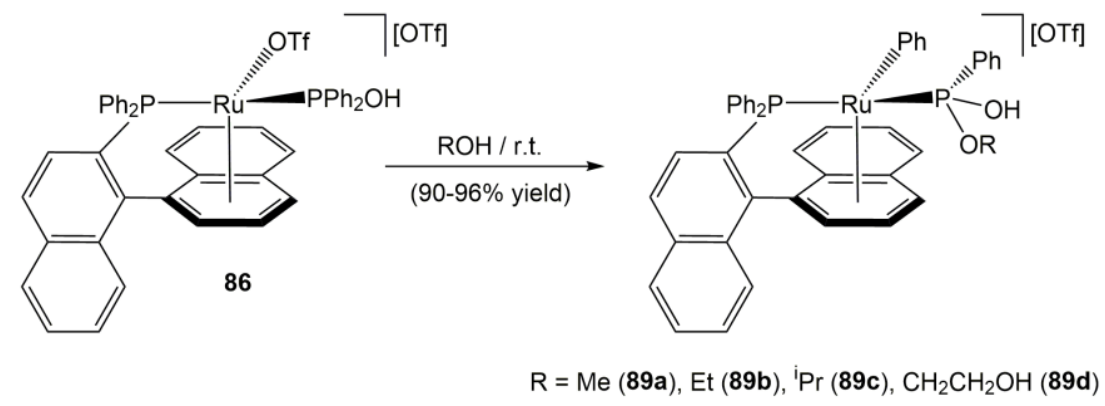

Scheme 24. Reactions of complex 86 with alcohols.
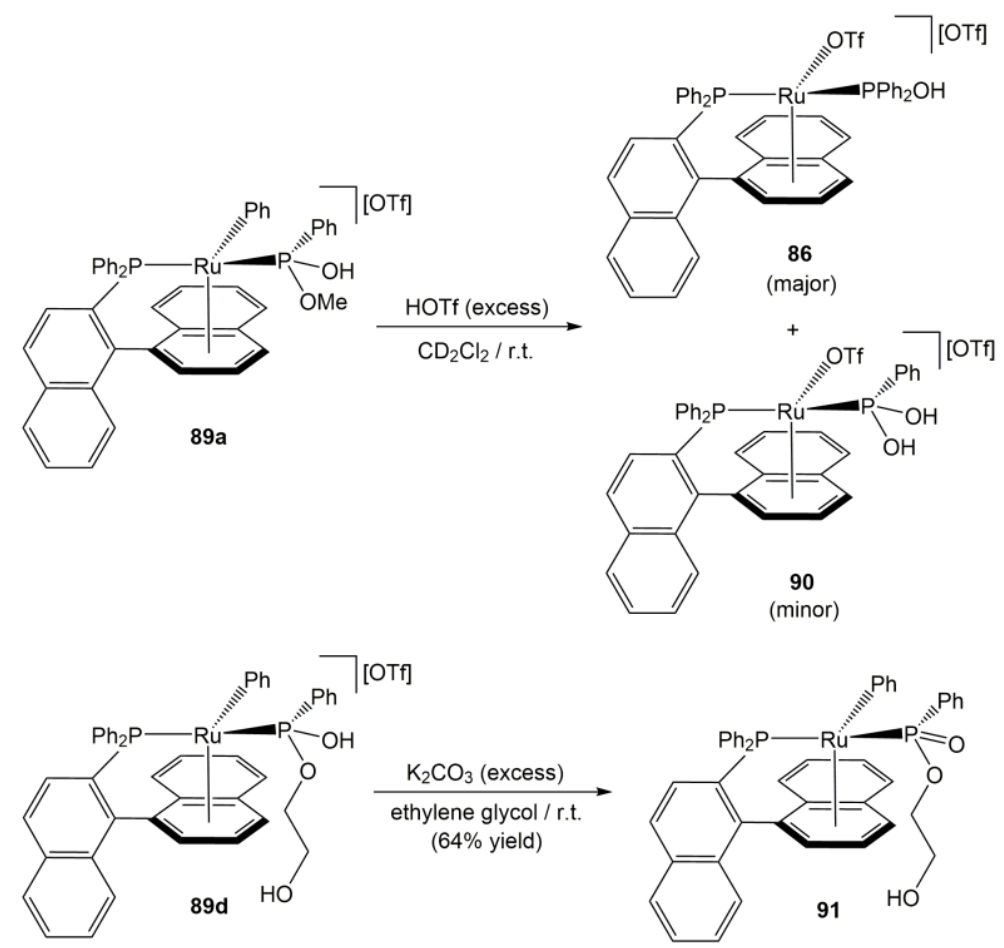

Scheme 25. Protonation and deprotonation reactions of complexes 89a and 89d. 
Remarkably, the formation of compounds 89a-d was found to be reversible. Thus, experiments performed in NMR tubes with $\mathrm{CD}_{2} \mathrm{Cl}_{2}$ solutions of these complexes indicated that compound $\mathbf{8 6}$ is almost quantitatively regenerated upon addition of an excess of triflic acid [80]. Only in the case of 89a minor amounts of a side product $\mathbf{9 0}$, containing $\mathrm{PPh}(\mathrm{OH})_{2}$ as ligand, were formed (Scheme 25). As exemplified with the transformation of 89d into 91 (Scheme 25), the deprotonation of the $\mathrm{PPh}(\mathrm{OR})(\mathrm{OH})$ ligands in complexes $\mathbf{8 9}$ also proceeded cleanly in the presence of potassium carbonate.

An interesting result was obtained when complex $\mathbf{8 6}$ was reacted with ${ }^{\mathrm{t}} \mathrm{BuOH}$ in a $\mathrm{THF} / \mathrm{H}_{2} \mathrm{O}$ mixture since the dinuclear compound 92, containing the phosphorous acid anion $\mathrm{P}(=\mathrm{O})(\mathrm{OH})_{2}{ }^{-}$as bridging ligand, is selectively formed (Scheme 26) [81]. The anion $\mathrm{P}(=\mathrm{O})(\mathrm{OH})_{2}{ }^{-}$arises from the double $\mathrm{P}-\mathrm{C}$ bond cleavage in the initial phosphinous acid $\mathrm{Ph}_{2} \mathrm{POH}$ ligand of $\mathbf{8 6}$, a process apparently facilitated by the presence of water. $\mathrm{A}$ similar result was also obtained starting from the MeO-Biphep-derived complex $\mathbf{8 7}$, the reaction leading to the isolation of 93 [80]. In addition, related $\mathrm{P}-\mathrm{C}$ bond splitting processes were also found in the reactions of complex $\mathbf{8 8}$ (see Figure 12) with methanol, from which species related to 89a and 92 could be characterized [77].

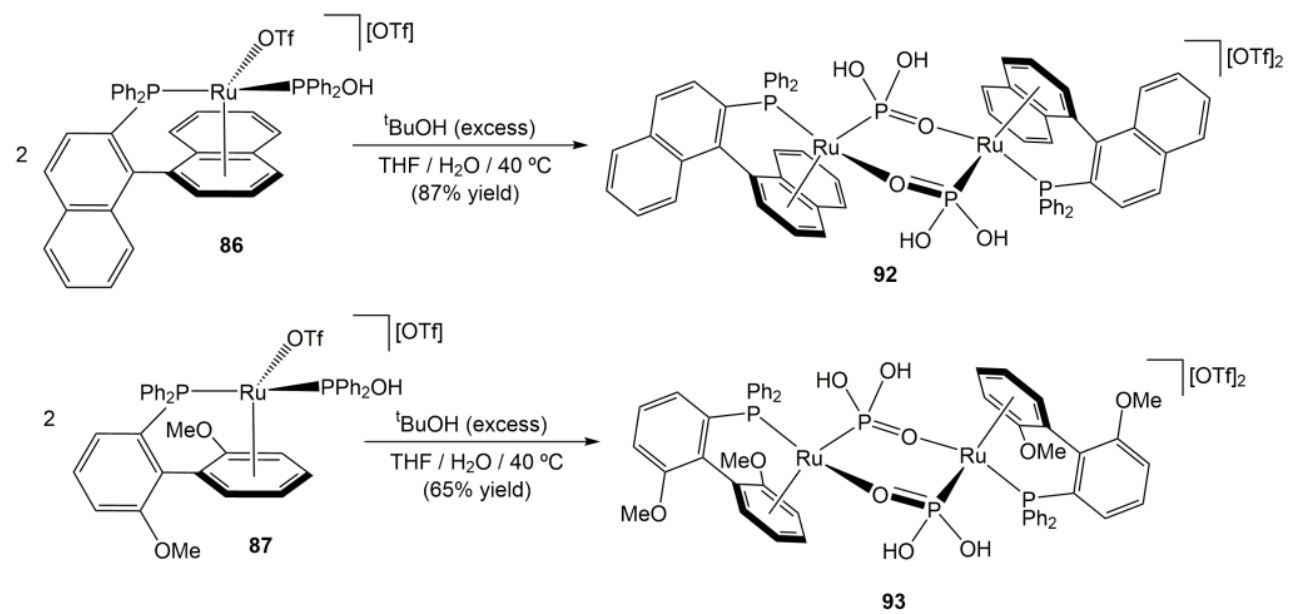

Scheme 26. Synthesis of the dinuclear complexes 92 and 93. 


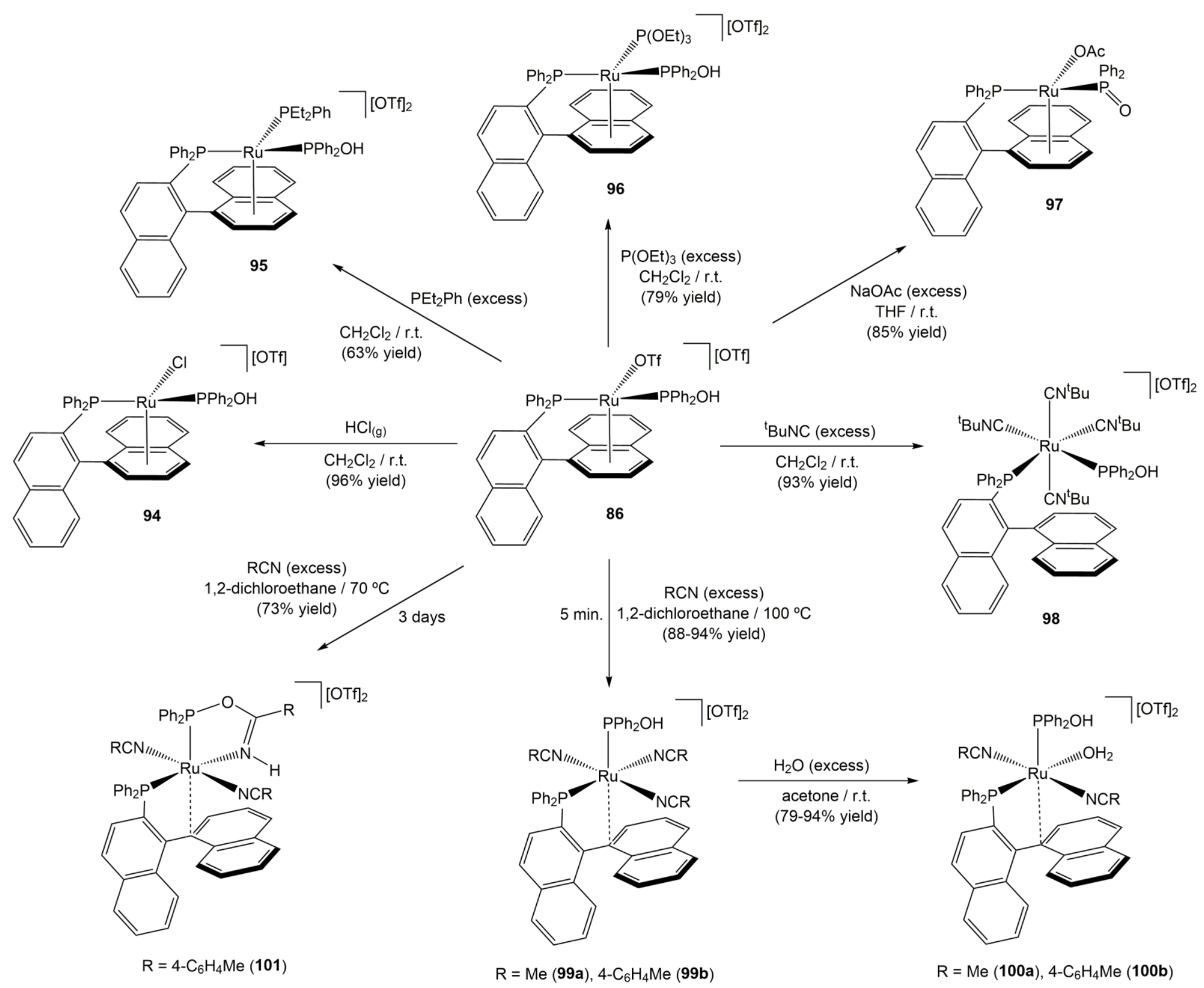

Scheme 27. Reactivity of complex $\mathbf{8 6}$ towards anionic and neutral ligands. 
In addition to alcohols, the reactivity of $\mathbf{8 6}$ was extended to $\mathrm{HCl}$, phosphines, phosphites, sodium acetate, isonitriles and nitriles $[77,82,83]$. A summary is given in Scheme 27. Depending on the reagent employed different reaction pathways were observed, involving simple substitution of the labile triflate ligand (compounds 94-96), the deprotonation of the $\mathrm{PPh}_{2} \mathrm{OH}$ unit (compound 97), the full displacement of the coordinated $\eta^{6}$-coordinated arene (compound 98), or a change in its hapticity from $\eta^{6}$ to $\eta^{1}$, in which a weak bonding of the $\mathrm{C}_{\mathrm{ipso}}$-biaryl arene carbon to ruthenium is established (compounds 99-100). Worthy of note is also the formation of the metallacyclic complex 101 after prolonged heating of a 1,2-dichloroethane solution of 86 with an excess of $p$ tolyl nitrile [82]. This compound results from the nucleophilic addition of the $\mathrm{PPh}_{2} \mathrm{OH}$ ligand to a ruthenium-coordinated nitrile molecule.

A P-C bond splitting process was observed when the cationic cyclometalated ruthenium(II) complexes $\mathbf{1 0 2}$ were treated with an excess of sodium hydride in wet tetrahydrofuran, the reactions leading to the selective formation of the neutral phosphinito derivatives 103, which could be converted into the corresponding phosphinous acid complexes 104 by protonation with $\mathrm{HBF}_{4} \cdot \mathrm{OEt}_{2}$ (Scheme 28) [84]. Protonation of the cationic phosphinito- $\mathrm{Ru}(\mathrm{II})$ derivative

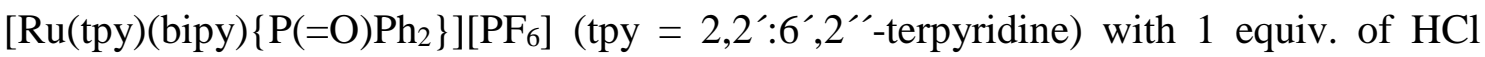
was described by Campagna, Igau and co-workers [85]. After counteranion exchange with $\mathrm{KPF}_{6}$, the dinuclear $\mathrm{H}$-bonded complex $\left[\left\{\mathrm{Ru}(\text { tpy })(\text { bipy })\left(\mathrm{PPh}_{2} \mathrm{O}\right)\right\}_{2} \mathrm{H}\right]\left[\mathrm{PF}_{6}\right]_{3}$, structurally related to the iron derivatives 2 (see Scheme 1), could be isolated and crystallographically characterized. Interestingly, this compound was found to be water sensitive evolving into $\left[\left\{\mathrm{Ru}(\text { tpy })(\text { bipy })\left(\mathrm{PPh}_{2} \mathrm{O}\right)\right\}_{2}\left(\mathrm{H}_{2} \mathrm{O}\right)\right]\left[\mathrm{PF}_{6}\right]_{2}$, a rare example of a water-bridged dinuclear complex featuring a $\mathrm{P}=\mathrm{O} \cdots \mathrm{H}-\mathrm{O}-\mathrm{H} \cdots \mathrm{O}=\mathrm{P}$ linkage. 


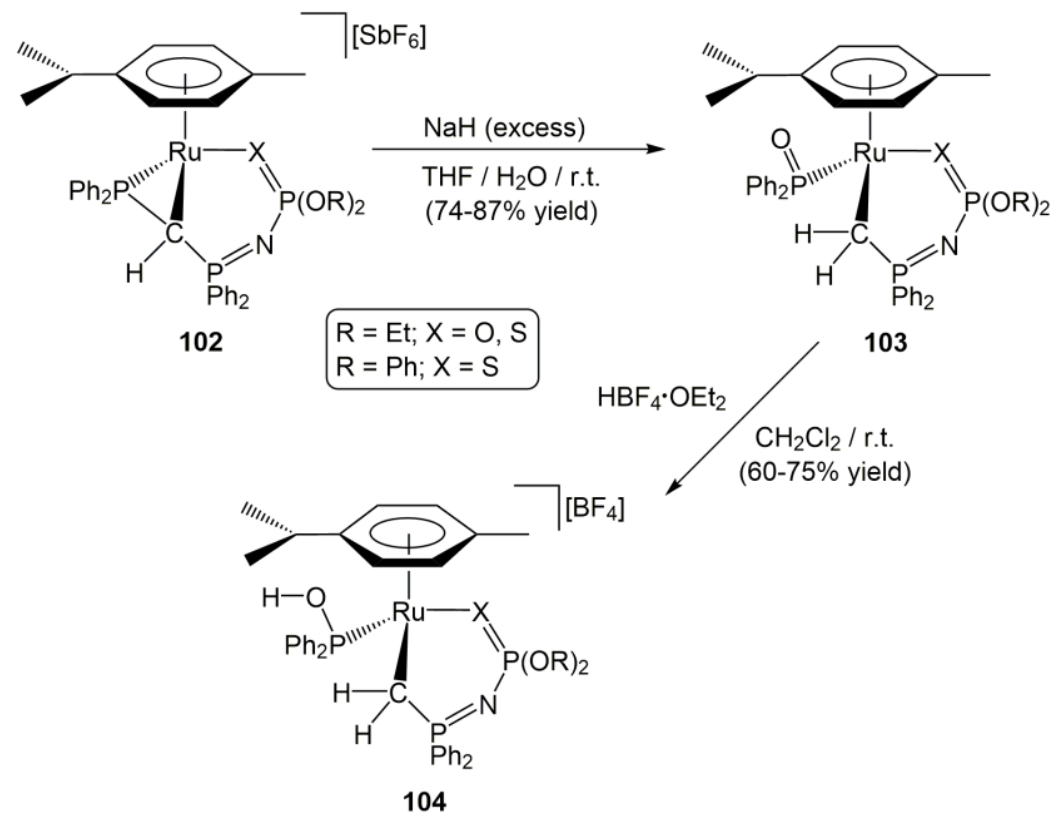

Scheme 28. Access to the diphenylphosphinous acid-Ru(II) complexes 104.

On another vein, interesting $\mathrm{P}-\mathrm{H}$ bond activation processes were described by PazSandoval and co-workers by exposing a solution of complex $\left[\mathrm{RuClCp} *\left(\mathrm{PHPh}_{2}\right)_{2}\right](\mathbf{1 0 5})$ in $\mathrm{CDCl}_{3}$ to the air [86]. As shown in Scheme 29, a mixture of several rutheniumcontaining products was formed, including: (i) the chlorophosphine complexes $\mathbf{1 0 6}$ and 107, generated through radical chlorination of the $\mathrm{PHPh}_{2}$ ligands by the $\mathrm{CDCl}_{3}$ solvent, and (ii) the phosphinous acid derivatives 108-110 generated by oxidation of the coordinated $\mathrm{PHPh}_{2}$ ligands. According to the authors, such oxidation could involve molecular oxygen activated by free radicals generated from $\mathrm{CDCl}_{3}$. Compounds $\mathbf{1 0 9}$ and 110, were independently synthesized and fully characterized by the direct reaction of the dimeric $\mathrm{Ru}(\mathrm{III})$ precursor $\left[\left\{\mathrm{RuCl}(\mu-\mathrm{Cl}) \mathrm{Cp}^{*}\right\}_{2}\right]$ with $\mathrm{Ph}_{2} \mathrm{P}(=\mathrm{O}) \mathrm{H}$. Another species observed in the $\mathrm{CDCl}_{3}$ solution was the hydride-ruthenium(IV) derivative 111, resulting from the intramolecular oxidative addition of one of the phosphinous acid $\mathrm{Ph}_{2} \mathrm{POH}$ ligands to ruthenium in $\mathbf{1 0 9}$, as confirmed in an independent experiment. 

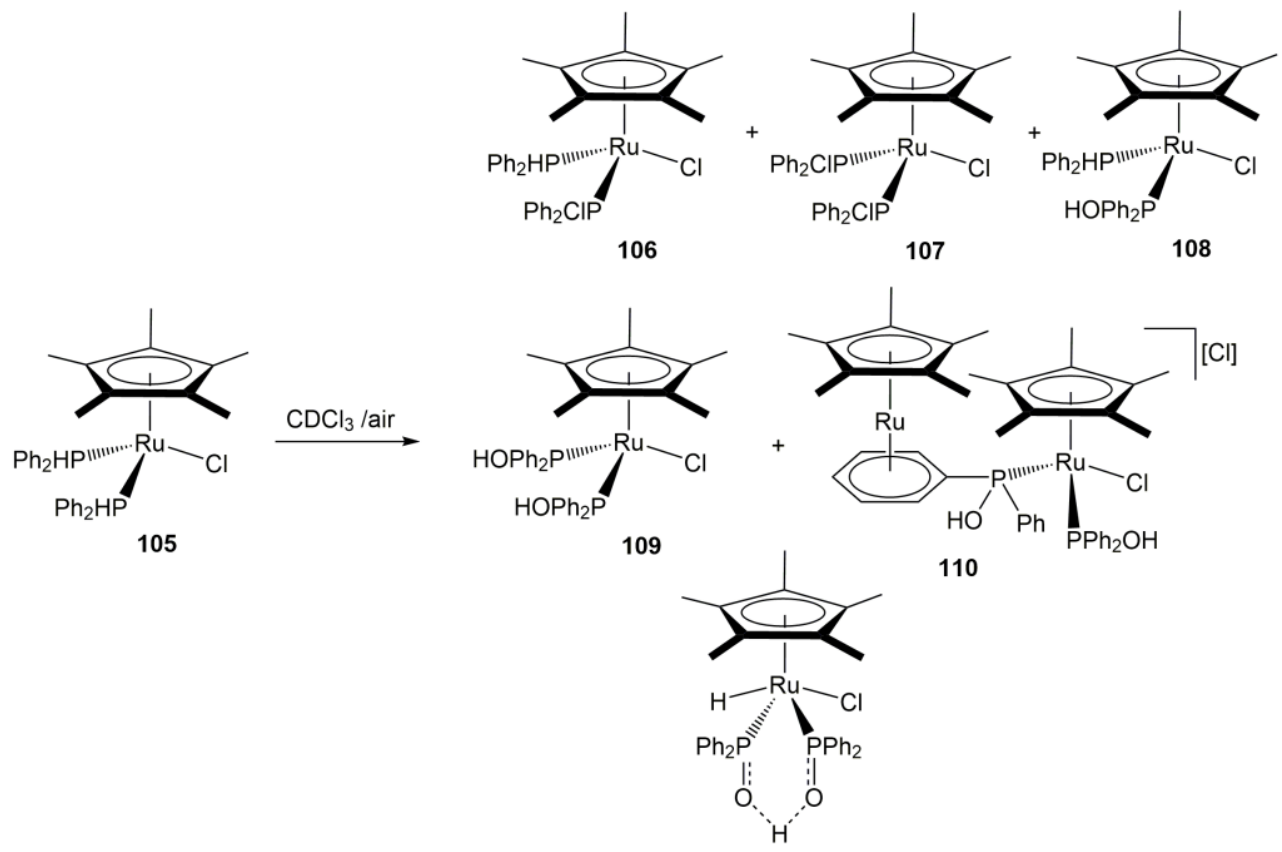

110

111

Scheme 29. Products resulting from the exposure of a $\mathrm{CDCl}_{3}$ solution of complex 105 to air.

In the same work, the $\mathrm{Ru}(\mathrm{II})$ and $\mathrm{Ru}(\mathrm{IV})$ complexes $\left[\mathrm{RuCp} *\left(\mathrm{PHPh}_{2}\right)_{2}\left(\mathrm{PPh}_{2} \mathrm{OH}\right)\right][\mathrm{Cl}] \quad(\mathbf{1 1 2}) \quad$ and $\quad\left[\mathrm{RuH}_{2} \mathrm{Cp}^{*}\left\{\left(\mathrm{PPh}_{2} \mathrm{O}\right)_{2} \mathrm{H}\right\}\right][\mathrm{Cl}] \quad(\mathbf{1 1 3})$, respectively, were also isolated during the purification by column chromatography over silica gel of the mixture of products generated in the reaction of $\left[\mathrm{RuClCp} *\left(\mathrm{PPh}_{3}\right)_{2}\right]$ with an excess of $\mathrm{PHPh}_{2}$ (Figure 13) [86].

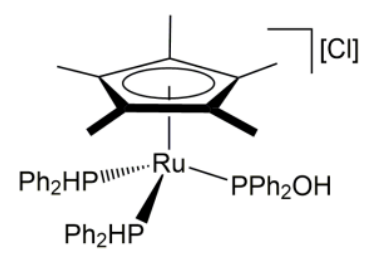

112

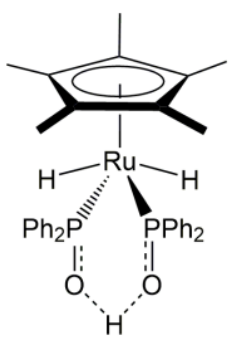

113

Figure 13. Structure of the ruthenium complexes 112 and 113. 
In addition to 111 and 113, other Ru(IV)-phosphinous acid complexes have appeared in the literature. In particular, Cadierno and co-workers described the synthesis of the mononuclear bis(allyl)-ruthenium(IV) derivatives $\left[\operatorname{RuCl}_{2}\left(\eta^{3}: \eta^{3}-\right.\right.$ $\left.\left.\mathrm{C}_{10} \mathrm{H}_{16}\right)\left(\mathrm{PR}_{2} \mathrm{OH}\right)\right](\mathbf{1 1 5 a}-\mathbf{h})$ by the direct reaction of different aromatic, heteroaromatic and aliphatic SPOs with the chloride-bridged dimeric precursor $\left[\left\{\mathrm{RuCl}(\mu-\mathrm{Cl})\left(\eta^{3}: \eta^{3}-\right.\right.\right.$ $\left.\left.\mathrm{C}_{10} \mathrm{H}_{16}\right)\right\}_{2}$ (114; $\mathrm{C}_{10} \mathrm{H}_{16}=$ 2,7-dimethylocta-2,6-diene-1,8-diyl) (Scheme 30) [87,88]. The reactions proceeded cleanly in dichloromethane at room temperature, affording 115a-h in good yields. Alternatively, compounds 115a-f, containing aromatic or heteroaromatic substituents on the $\mathrm{P}$ atom, were also accessible by hydrolysis of the corresponding chlorophosphine derivatives $\left[\mathrm{RuCl}_{2}\left(\eta^{3}: \eta^{3}-\mathrm{C}_{10} \mathrm{H}_{16}\right)\left(\mathrm{PR}_{2} \mathrm{Cl}\right)\right](\mathbf{1 1 6 a - f})$ in a $\mathrm{THF} / \mathrm{H}_{2} \mathrm{O}$ mixture at $50{ }^{\circ} \mathrm{C}($ Scheme 30) [88].

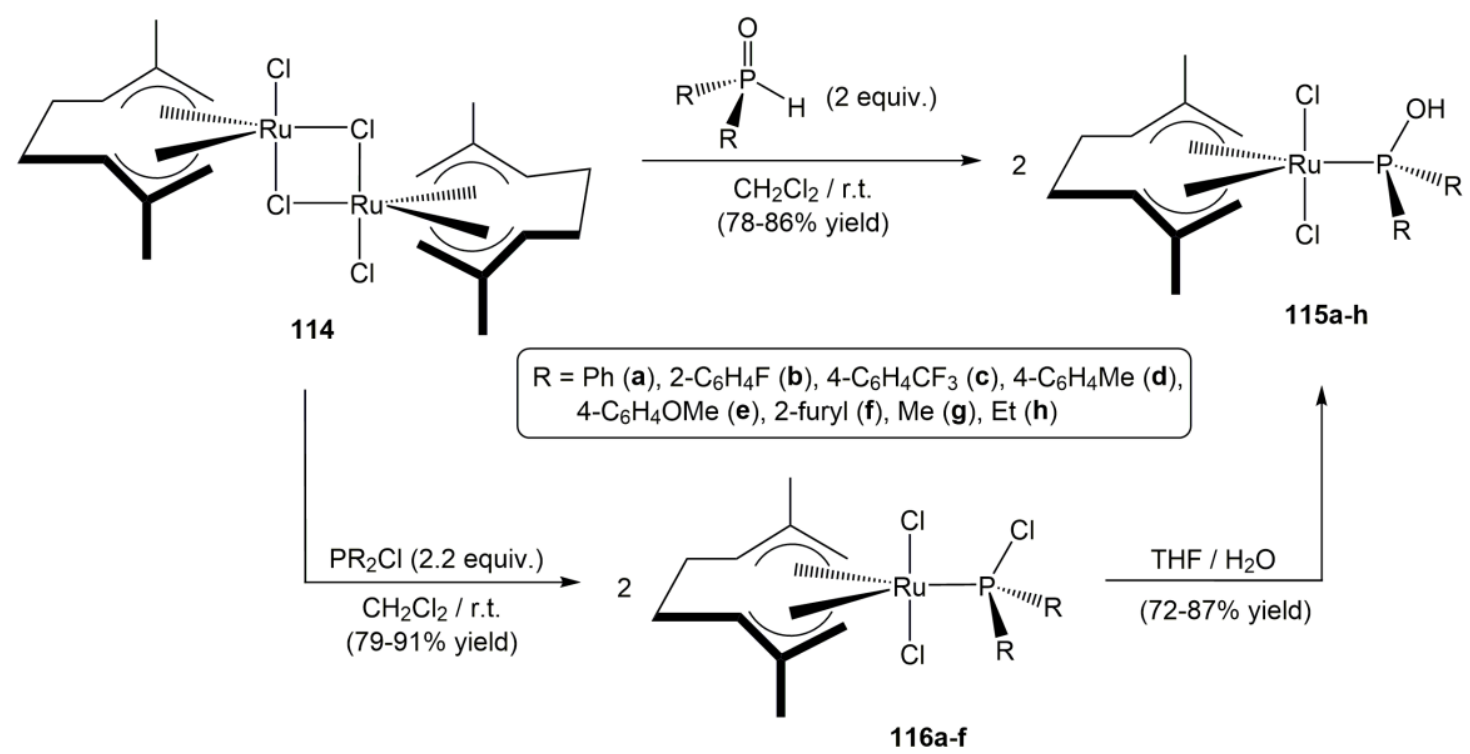

Scheme 30. Synthesis of the bis(allyl)-ruthenium(IV)-phosphinous acid complexes 115a-h.

Very recently, while studying the coordination chemistry of the bidentate phosphino-phosphinine ligand 117, Mansell and co-workers reported the preparation of a couple of phosphinous acid-ruthenium(II) complexes via selective syn addition of 
water across a $\mathrm{P}=\mathrm{C}$ bond of the phosphinine unit (Scheme 31) [89]. Thus, they found that the reaction of $\mathbf{1 1 7}$ with the hexamethylbenzene-ruthenium(II) dimer $\mathbf{1 8 d}$, in the presence of humid $\mathrm{NH}_{4} \mathrm{PF}_{6}$, leads to the clean formation of the cationic complex 118 in which, in addition to the hydration of the $\mathrm{P}=\mathrm{C}$ bond, cleavage of the $\mathrm{SiMe}_{3}$ group also takes place. Conversely, employing as the ruthenium source the tetrameric derivative $\left[\left\{\mathrm{Ru}(\mu-\mathrm{Cl}) \mathrm{Cp}^{*}\right\}_{4}\right]$, instead of dimer 18d, chelation of the intact phosphino-phosphinine ligand 117 to the $\mathrm{Cp} * \mathrm{RuCl}$ fragment was observed. However, in the presence of water, the resulted complex 119 also undergoes hydration to form $\mathbf{1 2 0 .}$

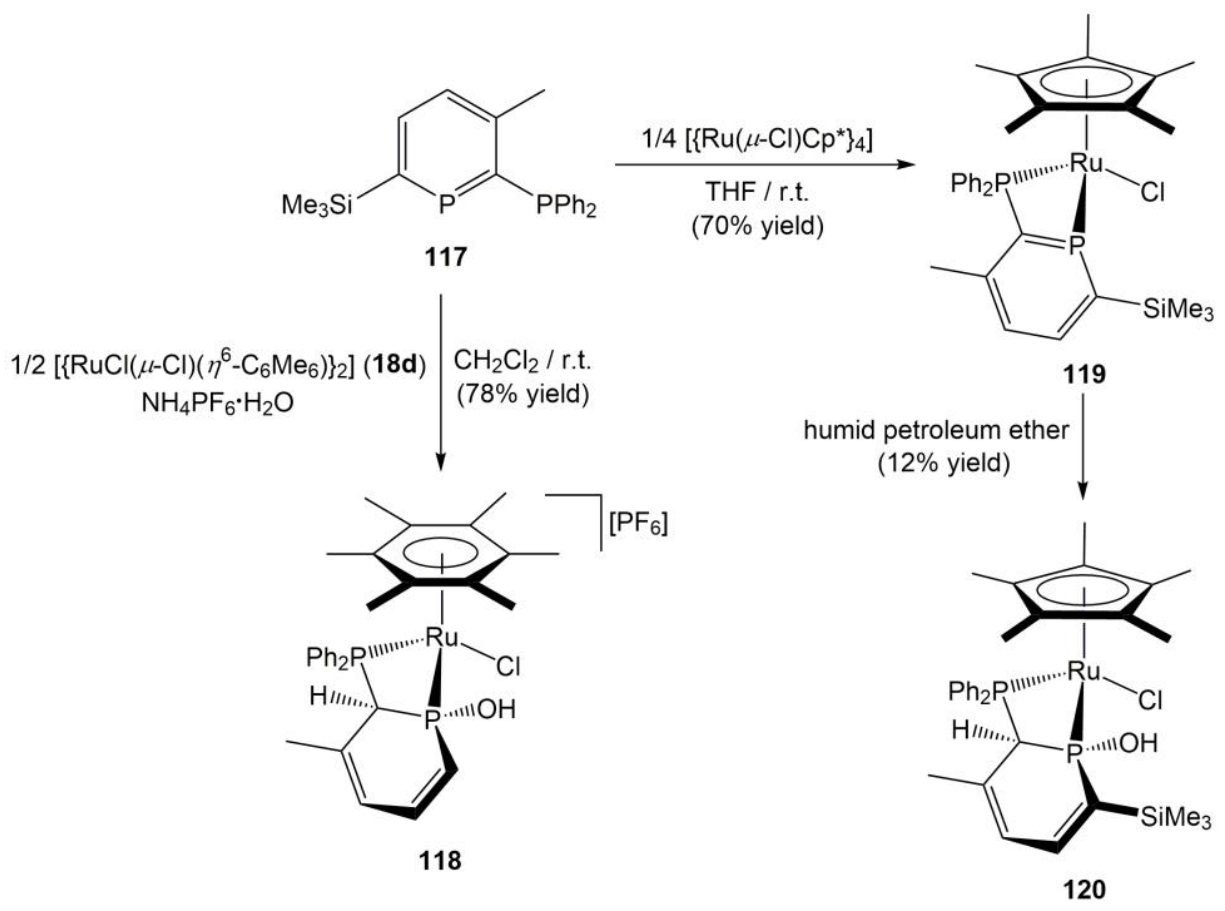

Scheme 31. Access to phosphinous acid-Ru(II) complexes by hydration of a phosphinophosphinine ligand.

\section{Synthesis and reactivity of osmium complexes}

The coordination of phosphinous and phosphorous acids to the ( $\eta^{6}-p$-cymene)osmium(II) fragment $\left[\mathrm{OsCl}_{2}\left(\eta^{6}-p\right.\right.$-cymene $\left.)\right]$ was described by Cadierno and co-workers [90]. In particular, they were able to synthesize in moderate to high yields complexes 
$\left[\mathrm{OsCl}_{2}\left(\eta^{6}-p\right.\right.$-cymene $\left.)\left(\mathrm{PR}_{2} \mathrm{OH}\right)\right] \quad(\mathrm{R}=\mathrm{Me}(\mathbf{1 2 2 a}), \mathrm{Ph}(\mathbf{1 2 2 b}))$ and $\left[\mathrm{OsCl}_{2}\left(\eta^{6}-p\right.\right.$ cymene $\left.)\left\{\mathrm{P}(\mathrm{OR})_{2} \mathrm{OH}\right\}\right](\mathrm{R}=\mathrm{Me}(\mathbf{1 2 3 a}), \mathrm{Ph}(\mathbf{1 2 3 b}))$ by reacting the dimeric precursor $\left[\left\{\mathrm{OsCl}(\mu-\mathrm{Cl})\left(\eta^{6}-p \text {-cymene }\right)\right\}_{2}\right](\mathbf{1 2 1})$ with the corresponding secondary phosphine oxide or phosphite in tetrahydrofuran at room temperature (Scheme 32). As observed with the ruthenium dimers $\left[\left\{\mathrm{RuCl}(\mu-\mathrm{Cl})\left(\eta^{6} \text {-arene }\right)\right\}_{2}\right](\mathbf{1 8 a}-\mathbf{d})$, the reactions involving phosphites required longer times than those with the SPOs (18-24 h vs 1-6 h). In the same work, compound $\left[\mathrm{OsCl}_{2}\left(\eta^{6}-p\right.\right.$-cymene $\left.)\left(\mathrm{PPh}_{2} \mathrm{OH}\right)\right](\mathbf{1 2 2 b})$ could also be synthesized in high yield $(84 \%)$ by hydrolysis of the $\mathrm{P}-\mathrm{Cl}$ bond in the corresponding chlorophosphine complex $\left[\mathrm{OsCl}_{2}\left(\eta^{6}-p\right.\right.$-cymene $\left.)\left(\mathrm{PPh}_{2} \mathrm{Cl}\right)\right]$ after prolonged heating in wet tetrahydrofuran (48 $\mathrm{h}$ under refluxing conditions), more drastic conditions to those required in the case of analogous ruthenium-chlorophosphine complexes $\left[\mathrm{RuCl}_{2}\left(\eta^{6}-p\right.\right.$-cymene $\left.)\left(\mathrm{PR}_{2} \mathrm{Cl}\right)\right]$ (74b-I) (Scheme 22), pointing to a lower reactivity of Os in these hydrolytic reactions. Further works by the same group also demonstrated the possibility of generating $\left[\mathrm{OsCl}_{2}\left(\eta^{6}-p\right.\right.$-cymene $\left.)\left(\mathrm{PPh}_{2} \mathrm{OH}\right)\right](\mathbf{1 2 2 b})$ from the amino-phosphine derivative $\left[\mathrm{OsCl}_{2}\left(\eta^{6}-\right.\right.$ p-cymene $\left.\left\{\mathrm{PPh}_{2}\left(\mathrm{NMe}_{2}\right)\right\}\right]$ by hydrolytic cleavage of the $\mathrm{P}-\mathrm{N}$ bond in refluxing water [91].

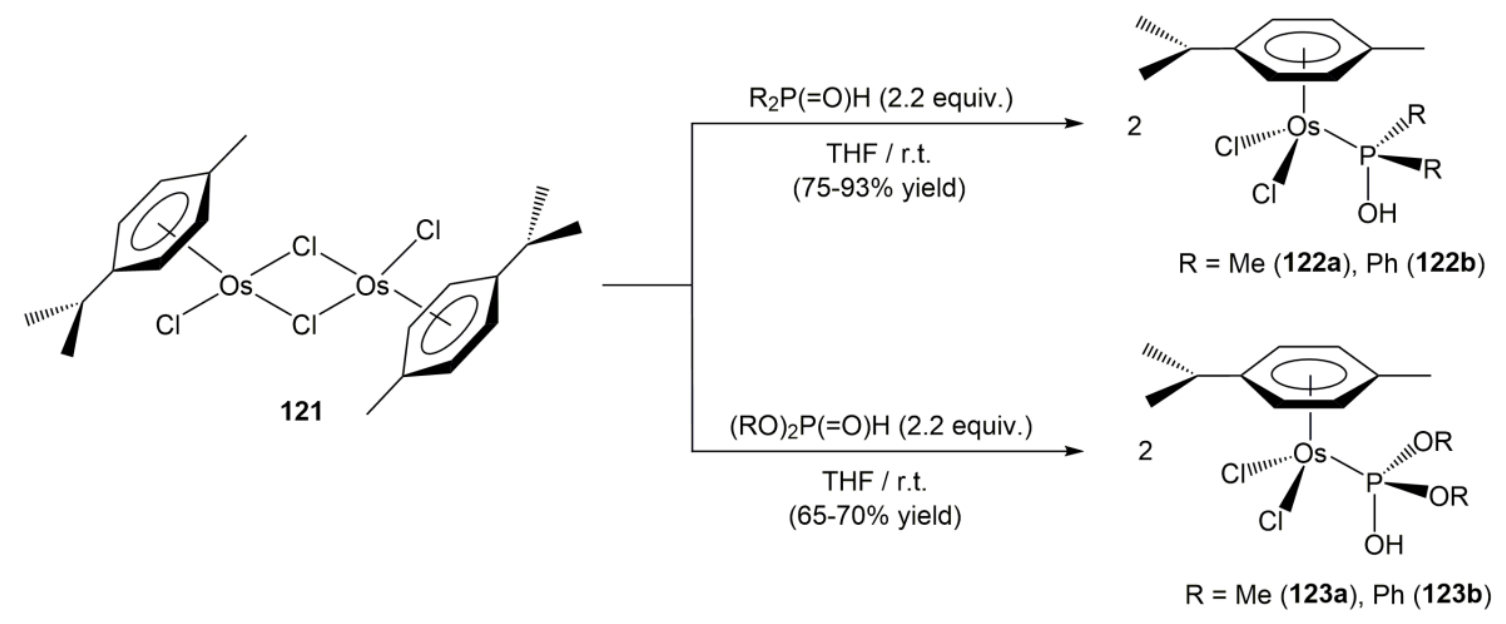

Scheme 32. Synthesis of the arene-Os(II) complexes 122a-b and 123a-b. 
Following analogous studies with iron and ruthenium [15,38-41], Peruzzini, Stoppioni and co-workers reported the high-yield preparation ( $c a .80 \%)$ of the cationic cyclopentadienyl-osmium(II) complexes $\left[\mathrm{OsCp}\left(\mathrm{PPh}_{3}\right)_{2}\left\{\mathrm{PR}(\mathrm{OH})_{2}\right\}\right][\mathrm{OTf}] \quad(\mathrm{R}=\mathrm{H}$ (124a), OH (124b)) (Figure 14) from the reactions of the corresponding neutral chloride precursor [OsClCp$\left.\left(\mathrm{PPh}_{3}\right)_{2}\right]$ with hypophosphorous and phosphorous acid $\left(\mathrm{H}_{3} \mathrm{PO}_{2}\right.$ and $\mathrm{H}_{3} \mathrm{PO}_{3}$ ) in the presence of AgOTf [92]. As expected, compounds $\mathbf{1 2 4 a}$ and $\mathbf{1 2 4 b}$ are also generated in the reactions of the mono- and dinuclear tetraphosphorus complexes 125 and 126 (Figure 14) with water, although as a complicated mixture with other compounds (including free $\mathrm{H}_{3} \mathrm{PO}_{2}$ and $\mathrm{H}_{3} \mathrm{PO}_{3}$, $\left[\mathrm{OsCp}\left(\mathrm{PPh}_{3}\right)_{2}\left(\mathrm{PH}_{3}\right)\right][\mathrm{OTf}]$ and other unidentified species) [92].

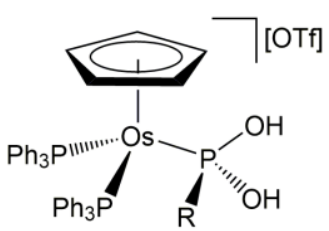

$\mathrm{R}=\mathrm{H}(124 \mathrm{a}), \mathrm{OH}(124 \mathrm{~b})$

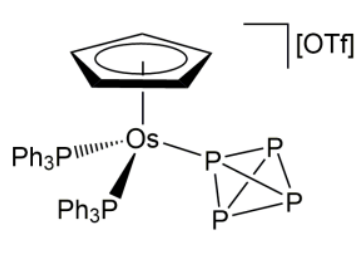

125

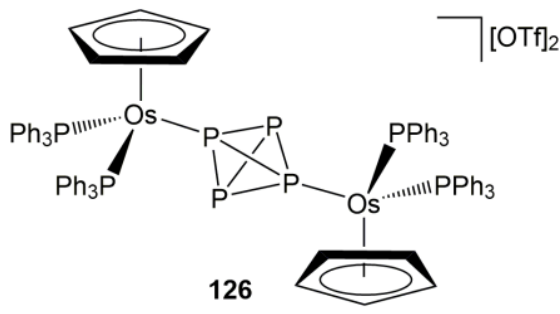

Figure 14. Structure of the cyclopentadienyl-osmium(II) complexes 124-126.

A surprising result was reported in 2000 by Esteruelas and co-workers with the isolation of the cationic diphenylphosphinous acid-Os(IV) complex $\left[\mathrm{OsH}_{2} \mathrm{Cp}\left(\mathrm{P}^{\mathrm{i}} \mathrm{Pr}_{3}\right)\left(\mathrm{PPh}_{2} \mathrm{OH}\right)\right]\left[\mathrm{PF}_{6}\right]$ (128) upon treatment of the neutral Os(II) chloride precursor $\left[\mathrm{OsClCp}\left(\mathrm{P}^{\mathrm{i}} \mathrm{Pr}_{3}\right)\left(\mathrm{PHPh}_{2}\right)\right]$ (127) with $\mathrm{TlPF}_{6}$ in humid acetone (Scheme 33) [93]. A reaction mechanism involving the intramolecular P-H oxidative addition of the diphenylphosphine ligand in the unsaturated species $\left[\mathrm{OsCp}\left(\mathrm{P}^{\mathrm{i}} \mathrm{Pr}_{3}\right)\left(\mathrm{PHPh}_{2}\right)\right]\left[\mathrm{PF}_{6}\right](\mathbf{J})$, generated by the initial abstraction of the chloride ligand of $\mathbf{1 2 7}$ with the thallium(I) salt, followed by the addition of a water molecule across the osmium-phosphido bond in the resulting hydride-phosphido intermediate $\left[\mathrm{OsHCp}\left(\mathrm{P}^{\mathrm{i}} \mathrm{Pr}_{3}\right)\left(\mathrm{PPh}_{2}\right)\right]\left[\mathrm{PF}_{6}\right]$ (K), was 
proposed by the authors to account for this unexpected result. This mechanistic proposal was supported by the selective generation of $\left[\mathrm{OsHDCp}\left(\mathrm{P}^{\mathrm{i}} \mathrm{Pr}_{3}\right)\left(\mathrm{PPh}_{2} \mathrm{OD}\right)\right]\left[\mathrm{PF}_{6}\right]$ when the same reaction was performed in a $\mathrm{D}_{2} \mathrm{O}$ /acetone mixture. On the other hand, the deprotonation of complex $\left[\mathrm{OsH}_{2} \mathrm{Cp}\left(\mathrm{P}^{\mathrm{i}} \mathrm{Pr}_{3}\right)\left(\mathrm{PPh}_{2} \mathrm{OH}\right)\right]\left[\mathrm{PF}_{6}\right]$ (128) with sodium methoxide allowed the high-yield preparation of the corresponding dihydridephosphinite-osmium(IV) derivative $\left[\mathrm{OsH}_{2} \mathrm{Cp}\left\{\mathrm{P}(=\mathrm{O}) \mathrm{Ph}_{2}\right\}\left(\mathrm{P}^{\mathrm{i}} \mathrm{Pr}_{3}\right)\right]$ (129) (Scheme 33) [93].

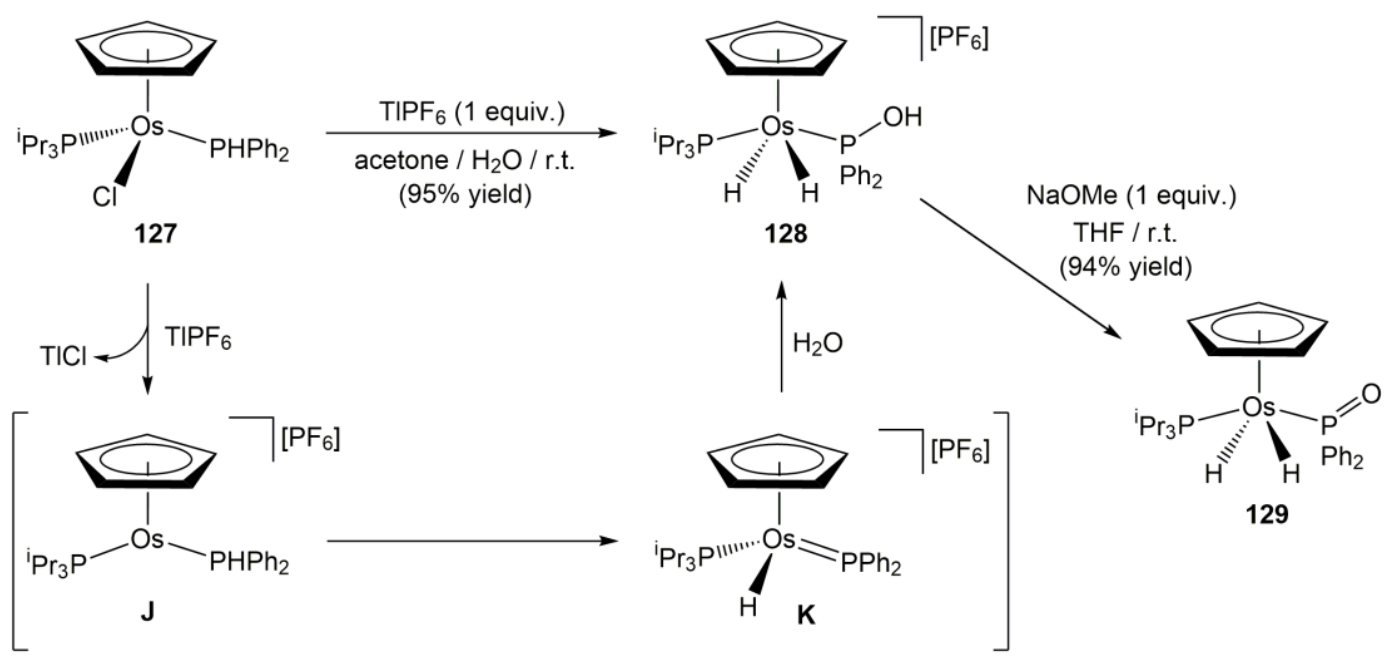

Scheme 33. Synthesis and deprotonation of the diphenylphosphinous acid Os(IV) complex 128.

The same group also described the synthesis of the diphenylphosphinous acid derivative $\left[\mathrm{OsH}_{5}\left(\mathrm{P}^{\mathrm{i}} \mathrm{Pr}_{3}\right)_{2}\left(\mathrm{PPh}_{2} \mathrm{OH}\right)\right]\left[\mathrm{BF}_{4}\right](\mathbf{1 3 1})$ from the reaction of the pentahydridediphenylphosphine-osmium(VI) complex $\left[\mathrm{OsH}_{5}\left(\mathrm{P}^{\mathrm{i}} \mathrm{Pr}_{3}\right)_{2}\left(\mathrm{PHPh}_{2}\right)\right]\left[\mathrm{BF}_{4}\right](\mathbf{1 3 0})$ with water (Scheme 34) [94]. Given the tendency of $\mathbf{1 3 0}$ to lose a hydrogen molecule, a reaction pathway similar to that depicted in Scheme 33, and involving the oxidative addition of the $\mathrm{PHPh}_{2}$ ligand in the coordinatively unsaturated Os(IV) fragment $\left[\mathrm{OsH}_{3}\left(\mathrm{P}^{\mathrm{i}} \mathrm{Pr}_{3}\right)_{2}\left(\mathrm{PHPh}_{2}\right)\right]^{+}$, was suggested by the authors. 


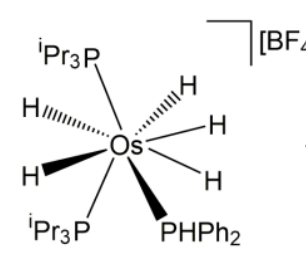

130

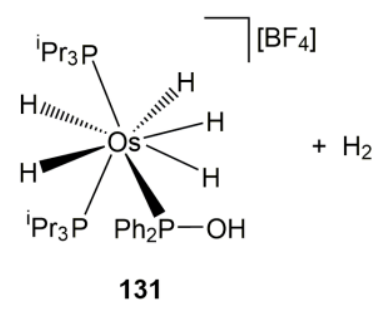

131

Scheme 34. Synthesis of the diphenylphosphinous acid Os(VI) complex 131.

Another interesting result was found by Che and co-workers while studying the reactivity of the porphyrin-Os(VI) derivative $\left[\mathrm{Os}\left(\mathrm{F}_{20}-\mathrm{tpp}\right) \mathrm{O}_{2}\right] \quad\left(\mathbf{1 3 2} ; \mathrm{F}_{20}\right.$-tpp = 5,10,15,20-tetrakis(pentafluorophenyl)porphyrinato dianion) towards diphenylphosphine (Scheme 35) [95]. Thus, the treatment of 132 with a large excess of $\mathrm{PHPh}_{2}$, in ethanol at room temperature, led to the major formation of the Os(II) complex $\left[\mathrm{Os}\left(\mathrm{F}_{20}-\mathrm{tpp}\right)\left(\mathrm{PHPh}_{2}\right)\left(\mathrm{PPh}_{2} \mathrm{OH}\right)\right](\mathbf{1 3 3})$ along with minor amounts of $\left[\mathrm{Os}\left(\mathrm{F}_{20^{-}}\right.\right.$ tpp)(PPh $2 \mathrm{OH})_{2}$ ] (134). Apparently, oxidation of $\mathrm{PHPh}_{2}$ by 132 readily takes place in solution generating $\mathrm{Ph}_{2} \mathrm{P}(=\mathrm{O}) \mathrm{H}$ and the reactive $\mathrm{Os}(\mathrm{II})$ species $\left[\mathrm{Os}\left(\mathrm{F}_{20}\right.\right.$-tpp $)$ ] to which diphenylphosphinous acid is preferentially coordinated. In line with this, no $\left[\mathrm{Os}\left(\mathrm{F}_{20^{-}}\right.\right.$ tpp $\left.)\left(\mathrm{PHPh}_{2}\right)_{2}\right]$ was detected after treating $\left[\mathrm{Os}\left(\mathrm{F}_{20}-\mathrm{tpp}\right)\left(\mathrm{PHPh}_{2}\right)\left(\mathrm{PPh}_{2} \mathrm{OH}\right)\right](\mathbf{1 3 3})$ with an excess of $\mathrm{PHPh}_{2}$ in dichloromethane, suggesting all these results that the binding of $\mathrm{PPh}_{2} \mathrm{OH}$ to osmium is substantially stronger than that of $\mathrm{PHPh}_{2}$.

The generation of phosphinous acid ligands by hydrolytic cleavage of P-C bonds in osmium-coordinated phosphines has also been reported. In particular, the dicationic aquo-complexes 135 and 136, containing optically active phosphinooxazoline ligands (both compounds exist as non-separable mixtures of diastereoisomers), were found to evolve in dichloromethane solution into the monocationic osmium(II) derivatives $\mathbf{1 3 7}$ and 138, respectively, in which one of the phenyl groups of the original phosphine is replaced by $\mathrm{OH}$ and transferred to the metal (Scheme 36) [96]. 


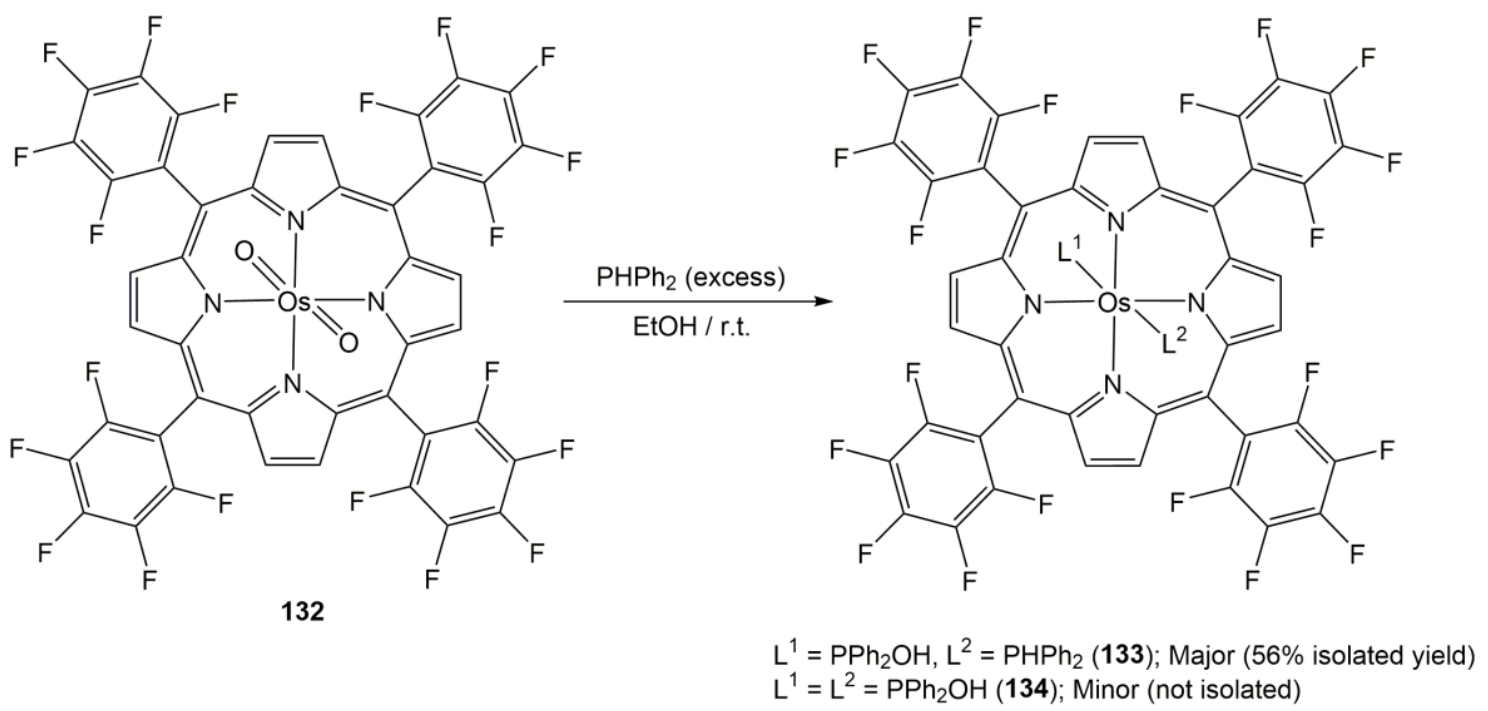

Scheme 35. Reactivity of the porphyrin-dioxo-Os(VI) derivative 132 towards $\mathrm{PHPh}_{2}$.
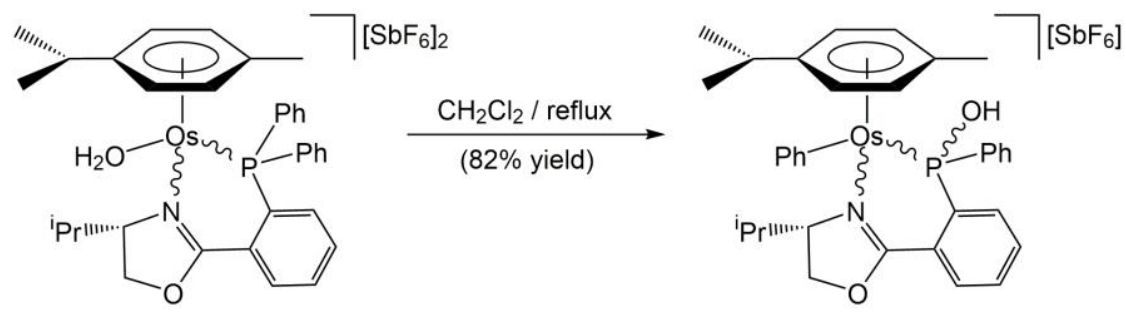

135

137
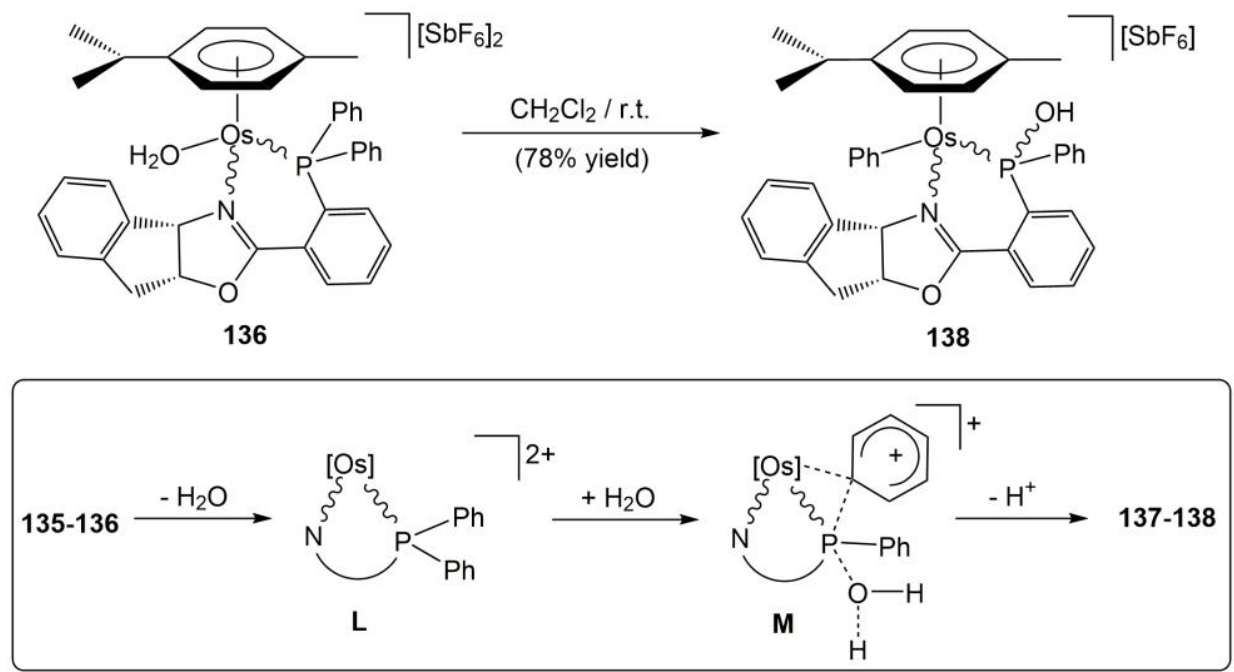

Scheme 36. Hydrolytic P-C cleavage reactions on dicationic arene-Os(II) complexes.

In the new compounds $\mathbf{1 3 7 - 1 3 8}$, the phosphorus atoms become also stereogenic centers. Nonetheless, according to the spectroscopic data obtained, the formation of 
both compounds proceeded in a stereospecific manner, the $\mathrm{P}$ atoms adopting the same configuration that the osmium atoms present. To rationalize the stereospecific formation of 137-138 the authors proposed the following reaction pathway: Initially, dissociation of the coordinated water molecules would generate the corresponding coordinatively unsaturated species $\mathbf{L}$. Once formed, these intermediates could undergo a [1,2]-shift of a phenyl group from phosphorus to osmium, promoted by the nucleophilic attack of the released water molecule on the phosphorus atom (transition state $\mathbf{M}$ ). For steric reasons, this nucleophilic attack takes place on the opposite site of the osmium-phosphorus phenyl bridge, which would explain the observed stereospecificity.

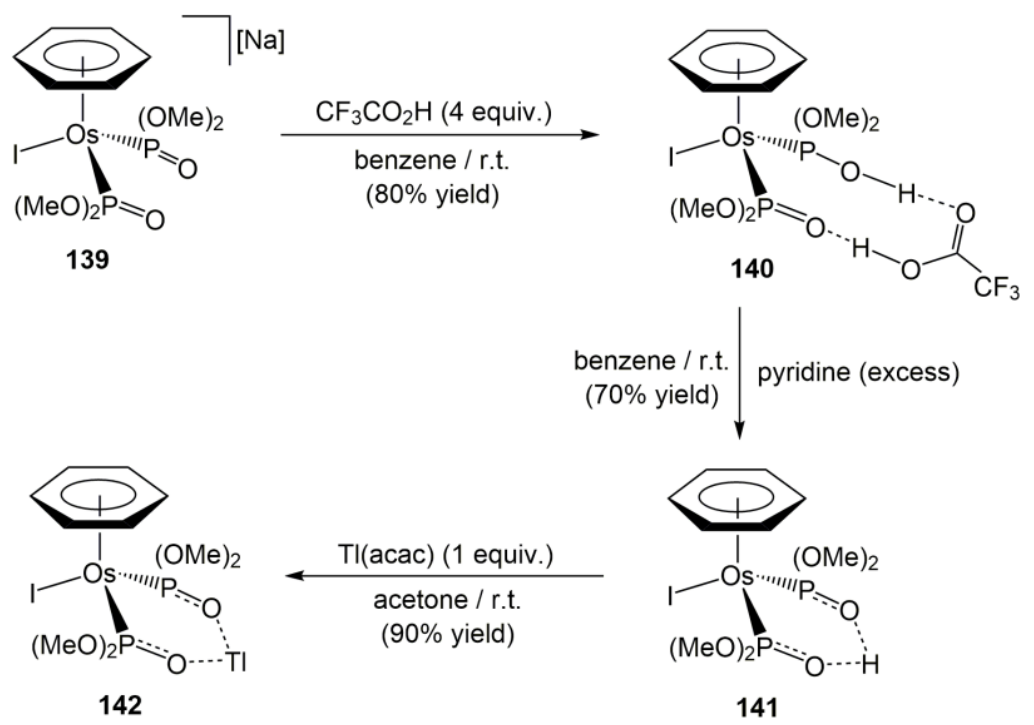

Scheme 37. Synthesis and reactivity of the arene-Os(II) complex 140.

An additional example of an osmium complex with a P-OH ligand is the benzeneOs(II) complex 140, which contains a coordinated dimethylphosphorous acid molecule (Scheme 37) [97]. It was generated by protonation of the bis(dimethylphosphonate) derivative 139 with an excess of trifluoroacetic acid, and isolated as a hydrogen-bonded 1:1 adduct with the acid. Treatment of $\mathbf{1 4 0}$ with pyridine allowed the elimination of the 
$\mathrm{CF}_{3} \mathrm{CO}_{2} \mathrm{H}$ molecule and the isolation of complex 141. Further reaction of 141 with $\mathrm{Tl}(\mathrm{acac})$ resulted in the clean formation of the heterobimetallic derivative $\mathbf{1 4 2}$ through the exchange of the bridging $\mathrm{H}^{+}$by $\mathrm{Tl}^{+}$.

\section{Applications and involvement in catalysis}

\subsection{Nitrile hydration reactions}

The utility of phosphinous acids as auxiliary ligands in nitrile hydration reactions was first evidenced by Ghaffar and Parkins in 1995 with the hydride-platinum(II) complex $\left[\mathrm{PtH}\left\{\left(\mathrm{PMe}_{2} \mathrm{O}\right)_{2} \mathrm{H}\right\}\left(\mathrm{PMe}_{2} \mathrm{OH}\right)\right]$ (143) (Figure 15) [98]. This compound was found to be particularly effective for the selective conversion of organonitriles into primary amides under mild conditions, showing moreover an exquisite tolerance to other functional groups, features that have allowed its implementation in a huge number of synthetic processes [99].

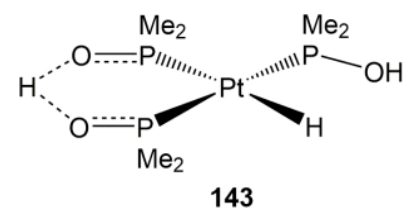

Figure 15. Structure of the Ghaffar-Parkins platinum catalyst 143.

Ruthenium complexes have been extensively investigated as potential catalysts for the hydration of nitriles during the last years [100], and excellent results have also been achieved when combined with phosphinous acid ligands. The first contribution to this field was made by Tyler and co-workers in 2013, who found that the dimethylphosphinous acid complex $\left[\mathrm{RuCl}_{2}\left(\eta^{6}-p\right.\right.$-cymene $\left.)\left(\mathrm{PMe}_{2} \mathrm{OH}\right)\right](\mathbf{2 0 a}$; see Figure 3) was able to hydrate a variety of nitriles in pure water and, more importantly, without the assistance of acidic or basic additives usually required in these hydration processes 
[29]. As shown in Scheme 38, the catalytic reactions proceeded cleanly at $100{ }^{\circ} \mathrm{C}$ with 5 mol\% of 20a, affording selectively the primary amide products in high yields and short times. Remarkably, working at low temperature (r.t.), complex $20 a$ proved to be also effective in the hydration of cyanohydrins, substrates very difficult to hydrate because they tend to decompose in aqueous media generating $\mathrm{HCN}$ that poisons the metal catalysts. The results obtained with glycolonitrile and lactonitrile (Scheme 38) showed that 20a was more active in the hydration of these challenging substrates than $\left[\mathrm{RuCl}_{2}\left(\eta^{6}-p\right.\right.$-cymene $\left.)\left\{\mathrm{P}\left(\mathrm{NMe}_{2}\right)_{3}\right\}\right]$, the best previously reported catalyst for cyanohydrin hydration [101].
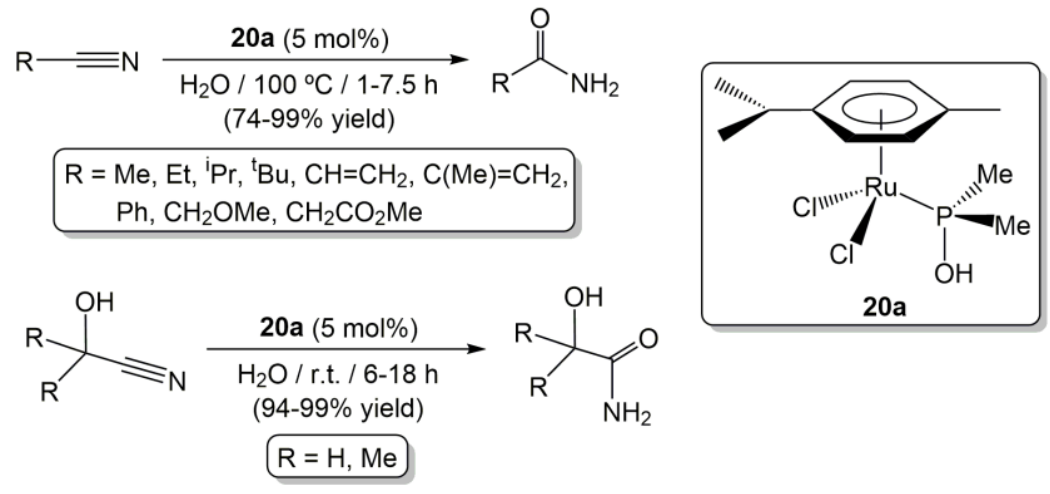

Scheme 38. Catalytic hydration of nitriles and cyanohydrins using the $\mathrm{Ru}(\mathrm{II})$ complex $20 \mathrm{a}$.

In a later work, and employing acetonitrile and benzonitrile as model substrates, Cadierno, López and co-workers evaluated comparatively the activity of a series of phosphinous acid complexes $\left[\mathrm{RuCl}_{2}\left(\eta^{6}\right.\right.$-arene $\left.)\left(\mathrm{PR}_{2} \mathrm{OH}\right)\right](\mathbf{1 9 - 2 2}$ in Figure 3$)$ with that of their phosphorous acid analogous $\left[\mathrm{RuCl}_{2}\left(\eta^{6}\right.\right.$-arene $\left.)\left\{\mathrm{P}(\mathrm{OR})_{2}(\mathrm{OH})\right\}\right](\mathbf{2 3 - 2 6}$ in Figure 3), finding that the former are much more effective than the latter [26]. From this study the dimethylphosphinous acid complexes $\left[\mathrm{RuCl}_{2}\left(\eta^{6}\right.\right.$-arene $\left.)\left(\mathrm{PMe}_{2} \mathrm{OH}\right)\right]($ arene $=$ benzene (19a), p-cymene (20a), mesitylene (21a), hexamethylbenzene (22a)) were identified as the most active, being able to complete the hydration of acetonitrile and benzonitrile at 
$100{ }^{\circ} \mathrm{C}$ in short time (from 5 min to $2 \mathrm{~h}$ ) with a metal loading of only $1 \mathrm{~mol} \%$. In addition, a mechanistic study through DFT calculations indicated that ligands $\mathrm{PR}_{2} \mathrm{OH}$ are deeply involved in the hydration process, playing a key role during the catalytic reactions (Scheme 39) [26]. According to the calculations, the hydration reactions do not proceed through the direct addition of water to the metal-coordinated nitrile. Instead, a five-membered metallacyclic intermediate is initially formed by intramolecular addition of the $\mathrm{OH}$ group of the phosphinous acid ligand to the nitrile. Subsequent hydrolysis of this metallacycle generates the final primary amide product. Additional evidences of the potential of these arene-ruthenium(II) complexes for $\mathrm{C} \equiv \mathrm{N}$ bond hydration reactions can be found in a patented work by Oshiki and Muranaka [27].

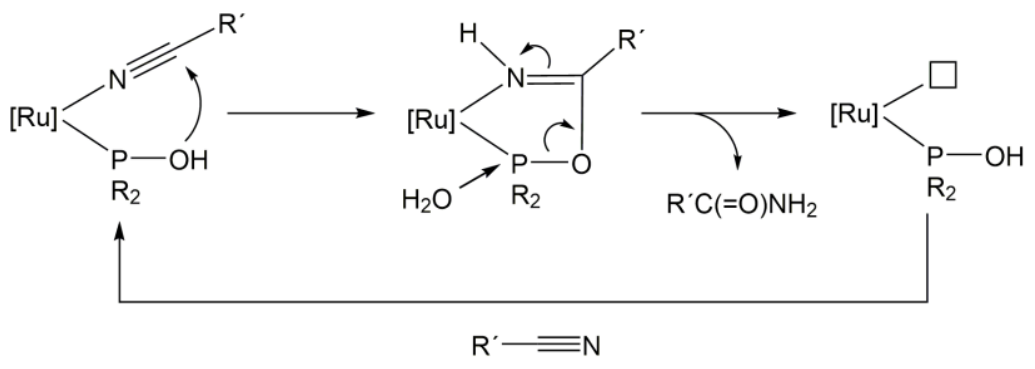

Scheme 39. The role played by $\mathrm{PR}_{2} \mathrm{OH}$ ligands in the $\mathrm{Ru}$-catalyzed hydration of nitriles.

The bis(allyl)-ruthenium(IV) complexes $\left[\mathrm{RuCl}_{2}\left(\eta^{3}: \eta^{3}-\mathrm{C}_{10} \mathrm{H}_{16}\right)\left(\mathrm{PR}_{2} \mathrm{OH}\right)\right](\mathbf{1 1 5 a}-\mathbf{h}$; see Scheme 30) have also shown an exceptional activity in the hydration of $\mathrm{C} \equiv \mathrm{N}$ bonds $[87,88]$. In particular, performing the catalytic reactions in pure water and in the absence of additives, the dimethylphosphinous acid derivative $\left[\mathrm{RuCl}_{2}\left(\eta^{3}: \eta^{3}-\mathrm{C}_{10} \mathrm{H}_{16}\right)\left(\mathrm{PMe}_{2} \mathrm{OH}\right)\right]$ (115g) was able to convert a huge number of aromatic, heteroaromatic, aliphatic and $\alpha, \beta$-unsaturated nitriles into the corresponding primary amides (up to 34 examples) in high yields ( $\geq 89 \%$ by gas chromatography) and short times (from 5 minutes to 8 hours) employing only $1 \mathrm{~mol} \%$ of $\mathrm{Ru}$ at $60^{\circ} \mathrm{C}$. The presence of common functional groups 
(halides, nitro, hydroxyl, ether, thioether or ketone) in the skeleton of the nitrile substrates was perfectly tolerated, thus highlighting the exquisite chemoselectivity of this catalyst. The synthetic utility of $\mathbf{1 1 5} \mathbf{g}$ was further evidenced with the selective synthesis of the antiepileptic drug rufinamide 145 and the NSAID ibuprofenamide 147 by hydration of their respective nitriles (144 and 146, respectively) (Scheme 40), as well as in the hydration of cyanohydrins. An additional outstanding feature of $\left[\operatorname{RuCl}_{2}\left(\eta^{3}: \eta^{3}-\right.\right.$ $\left.\left.\mathrm{C}_{10} \mathrm{H}_{16}\right)\left(\mathrm{PMe}_{2} \mathrm{OH}\right)\right](\mathbf{1 1 5 g})$ is that, due to its high solubility in water, it can be easily recycled after selective crystallization of the amide product at the end of the reaction just by cooling down the mixture (complex 115g remains completely dissolved in water, and the aqueous solution can be employed for additional reactions without appreciable loss of activity).<smiles>CC(C)(C)C#N</smiles>

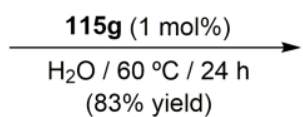
$(83 \%$ yield $)$

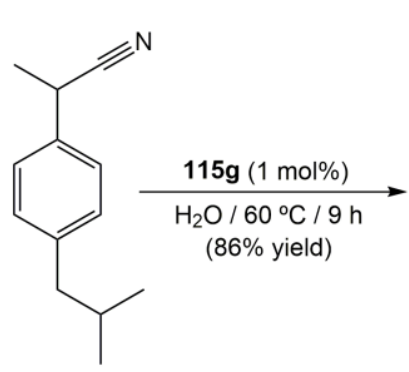

146
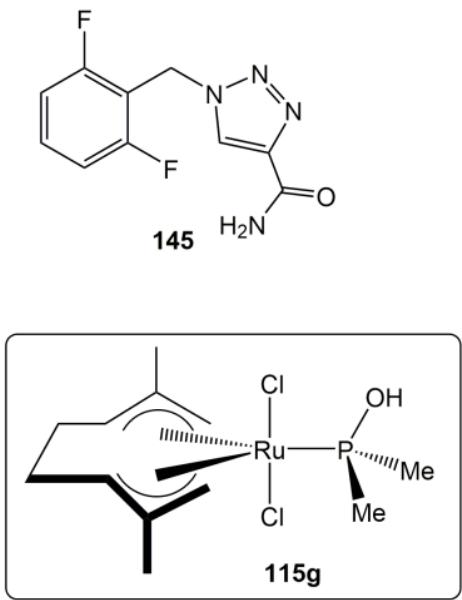

147

Scheme 40. Catalytic synthesis of rufinamide 145 and ibuprofenamide 147.

Another complex able to promote the selective hydration of nitriles to amides, also in pure water and under neutral conditions, is the cationic tethered ( $\eta^{6}$-arene)ruthenium(II) derivative 86 (see Scheme 23) [30]. However, its activity was found to be much lower in comparison to that shown by the neutral $\mathrm{Ru}(\mathrm{II})$ and $\mathrm{Ru}(\mathrm{IV})$ complexes 
just commented, requiring of a higher metal loading $(5 \mathrm{~mol} \%)$ and temperature $\left(100{ }^{\circ} \mathrm{C}\right)$ to operate. Perhaps the most relevant aspect of this compound is that it was also catalytically active in the rearrangement of aldoximes (Scheme 41) [30], an alternative atom-economical procedure for the synthesis of primary amides which involves a dehydration/rehydration sequence via the corresponding nitrile intermediates [102].
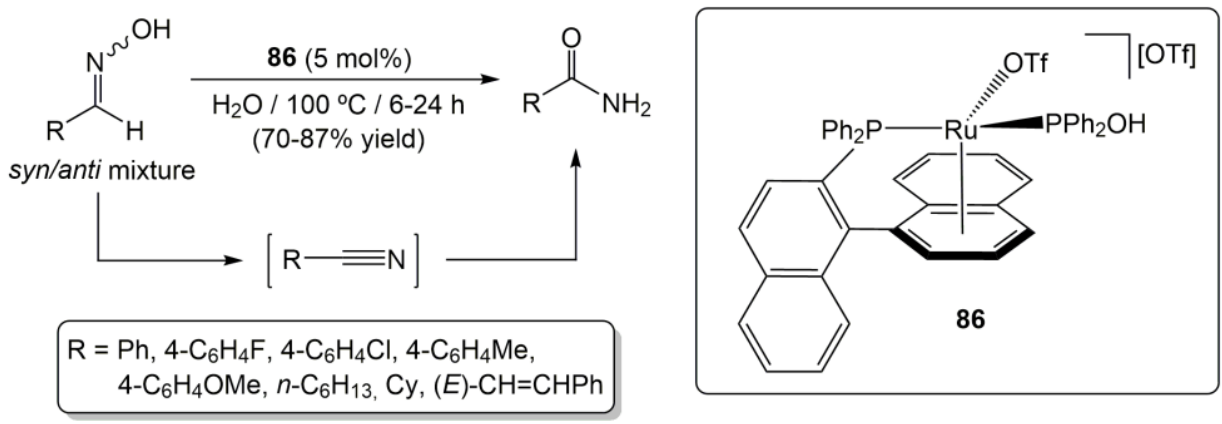

Scheme 41. The rearrangement of aldoximes into amides catalyzed by complex $\mathbf{8 6}$.

On the other hand, as previously commented in Section 5, ruthenium-phosphinous acid complexes can be easily accessed by hydrolysis of coordinated chlorophosphines. Consequently, ruthenium-chlorophosphine complexes can be potentially employed as pre-catalysts for nitrile hydration reactions, since in aqueous medium they would readily generate the catalytically active $\mathrm{Ru}-\mathrm{PR}_{2} \mathrm{OH}$ species. This possibility was confirmed by Cadierno and co-workers with the arene-ruthenium(II) complexes $\left[\mathrm{RuCl}_{2}\left(\eta^{6}-p\right.\right.$-cymene $\left.)\left(\mathrm{PR}_{2} \mathrm{Cl}\right)\right] \quad(\mathbf{7 4 b}-\mathbf{l} ;$ see Scheme 22) [32] and the bis(allyl)ruthenium(IV) derivatives $\left[\mathrm{RuCl}_{2}\left(\eta^{3}: \eta^{3}-\mathrm{C}_{10} \mathrm{H}_{16}\right)(\mathrm{PR} 2 \mathrm{Cl})\right]$ (116a-f; see Scheme 30) [88]. Employing directly water as solvent, all of them proved to be effective in the hydration reactions, with complex $\left[\mathrm{RuCl}_{2}\left(\eta^{6}-p\right.\right.$-cymene $\left.)\left\{\mathrm{PCl}\left(4-\mathrm{C}_{6} \mathrm{H}_{4} \mathrm{~F}\right)_{2}\right\}\right]$ (74g) showing a remarkable activity under mild conditions [32]. In particular, performing the reactions with only $2 \mathrm{~mol} \%$ of this complex at $40{ }^{\circ} \mathrm{C}$, a large number of aromatic, heteroaromatic, aliphatic and $\alpha, \beta$-unsaturated organonitriles could be selectively converted into the 
corresponding primary amides in high yields (> 77\% after $1-24 \mathrm{~h}$ ). The synthetic utility of this pre-catalyst was further evidenced with the preparation of a diverse family of synthetically useful $\beta$-ketoamides from the respective $\beta$-ketonitriles (Scheme 42), a hydration reaction whose only bibliographical precedents involved the use of enzymes, i.e. nitrile hydratases (NHases) [32].
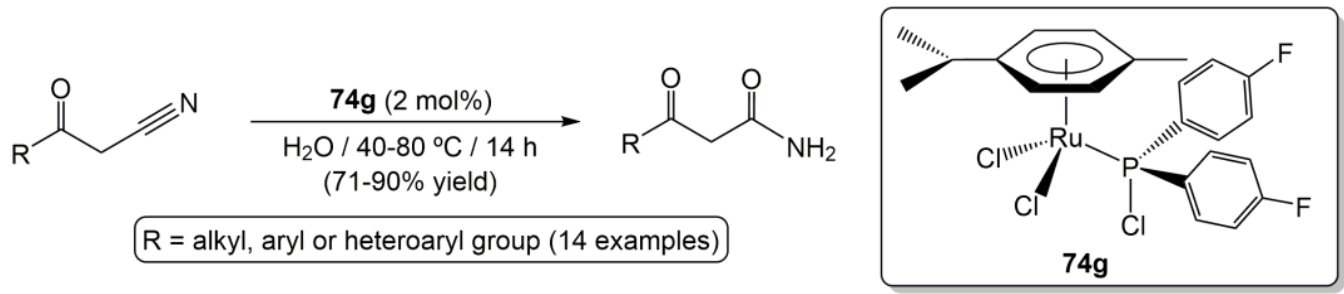

Scheme 42. Catalytic hydration of $\beta$-ketonitriles employing $\mathbf{7 4 g}$ as pre-catalyst.

In addition, taking advantage of the competence of ruthenium(II) complexes to catalyze the transfer hydrogenation (TH) of ketones by sodium formate in water [103], an efficient tandem hydration/TH process for the direct conversion of $\beta$-ketonitriles into $\beta$-hydroxyamides could be developed making use of $\left[\mathrm{RuCl}_{2}\left(\eta^{6}-p\right.\right.$-cymene $)\{\mathrm{PCl}(4-$ $\left.\left.\mathrm{C}_{6} \mathrm{H}_{4} \mathrm{~F}\right)_{2}\right\}$ ] (74g) as catalyst [104]. Thus, as shown in Scheme 43, performing the reactions in water at $100{ }^{\circ} \mathrm{C}$ for $24-48 \mathrm{~h}$, with $5 \mathrm{~mol} \%$ of $\mathbf{7 4 g}$ and 20 equiv. of $\mathrm{NaO}_{2} \mathrm{CH}$, a number of $\beta$-hydroxyamides could be synthesized in high yield. The increase in the $\mathrm{Ru}$ loading, temperature and time in comparison with the simple hydration reactions depicted in Scheme 42 was needed to facilitate the reduction of the corresponding $\beta$ ketoamide intermediates, which was found to be the rate-limiting step of this tandem process. Remarkably, under identical reaction conditions, the dimeric precursor $\left[\left\{\mathrm{RuCl}(\mu-\mathrm{Cl})\left(\eta^{6}-p \text {-cymene }\right)\right\}_{2}\right](\mathbf{1 8 b})$ and the related phosphine derivatives $\left[\mathrm{RuCl}_{2}\left(\eta^{6}-p\right.\right.$ cymene $\left.)\left(\mathrm{PPh}_{3}\right)\right]$ and $\left[\mathrm{RuCl}_{2}\left(\eta^{6}-p\right.\right.$-cymene $\left.)\left\{\mathrm{P}\left(4-\mathrm{C}_{6} \mathrm{H}_{4} \mathrm{~F}\right)_{3}\right\}\right]$ were unable to generate the 
final $\beta$-hydroxyamide products in significant amounts, thus pointing out the key role played by the in situ generated phosphinous acid ligand $\mathrm{P}\left(4-\mathrm{C}_{6} \mathrm{H}_{4} \mathrm{~F}\right)_{2} \mathrm{OH}$ in the process.

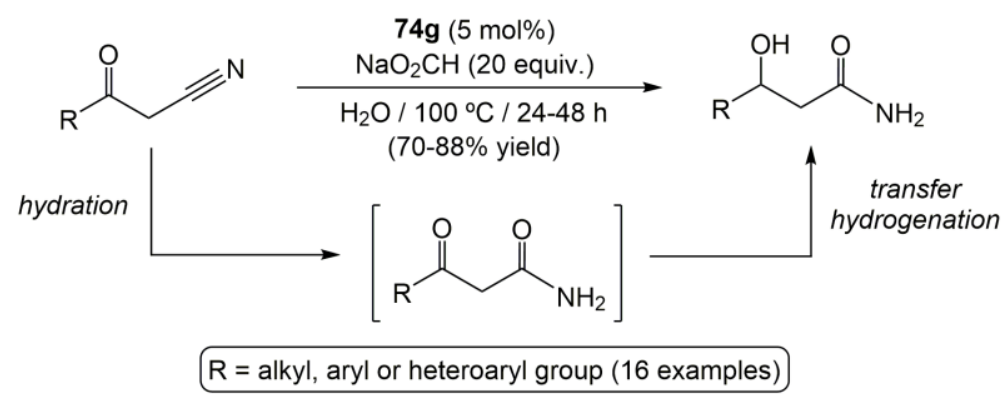

Scheme 43. Catalytic synthesis of $\beta$-hydroxyamides from $\beta$-ketonitriles.

Very recently, the combination of the bis(allyl)-ruthenium(IV) complex $\left[\mathrm{RuCl}_{2}\left(\eta^{3}: \eta^{3}-\mathrm{C}_{10} \mathrm{H}_{16}\right)\left(\mathrm{PMe}_{2} \mathrm{OH}\right)\right](\mathbf{1 1 5 g})$ with ketoreductases (KREDs) allowed the development a related hydration/bioreduction cascade process for the one-pot transformation of the same $\beta$-ketonitriles into the corresponding optically active $\beta$ hydroxyamides [105]. The reactions, which were in this case performed under mild temperature conditions $\left(60^{\circ} \mathrm{C}\right)$ in an aqueous phosphate buffer, proceeded in high yields and with a very high stereoselectivity (> 99\% ee in most cases). In addition, just by selecting the appropriate enzyme, it was possible to generate selectively one or the other enantiomer of the chiral $\beta$-hydroxyamide product.

Contrary to ruthenium [100], there are very few examples of osmium-based nitriles hydration catalysts reported to date in the literature [106]. Among them, complexes $\left[\mathrm{OsCl}_{2}\left(\eta^{6}-p\right.\right.$-cymene $\left.)\left(\mathrm{PR}_{2} \mathrm{OH}\right)\right](\mathrm{R}=\mathrm{Me}(\mathbf{1 2 2 a}), \mathrm{Ph}(\mathbf{1 2 2} \mathbf{b}))$ and $\left[\mathrm{OsCl}_{2}\left(\eta^{6}-\right.\right.$ $p$-cymene $\left.)\left\{\mathrm{P}(\mathrm{OR})_{2} \mathrm{OH}\right\}\right](\mathrm{R}=\mathrm{Me}(\mathbf{1 2 3 a}), \mathrm{Ph}(\mathbf{1 2 3 b}))$ (see Scheme 32) stand out, since they are able to operate in pure water without the assistance of any acidic or basic additive [90]. In terms of activity, the dimethylphosphinous acid derivative $\left[\mathrm{OsCl}_{2}\left(\eta^{6}-p\right.\right.$ cymene)(PMe $\left.\left.{ }_{2} \mathrm{OH}\right)\right](\mathbf{1 2 2 a})$ offered the best performances (TOF values up to $200 \mathrm{~h}^{-1}$ ), 
being able to convert a large variety of organonitriles into the corresponding primary amides in high yields and short times when the catalytic reactions were carried out at 80 ${ }^{\circ} \mathrm{C}$ with only $1 \mathrm{~mol} \%$ of Os (Scheme 44). It also noteworthy that 122a shows an activity challenging that of related Ru-based catalysts. In particular, when compared to its ruthenium counterpart $\left[\mathrm{RuCl}_{2}\left(\eta^{6}-p\right.\right.$-cymene $\left.)\left(\mathrm{PMe}_{2} \mathrm{OH}\right)\right](\mathbf{2 0 a})$, it turned out to hydrate faster the usually less reactive aliphatic nitriles, whereas the opposite trend was observed for aromatic substrates. DFT calculations supported, as in the case of ruthenium, the involvement in the catalytic reactions of five-membered metallacyclic intermediates generated by intramolecular addition of the $\mathrm{PMe}_{2} \mathrm{OH}$ ligand to the corresponding osmium-coordinated nitrile (see Scheme 39). According to the calculations, the differences in reactivity towards aliphatic and aromatic nitriles experimentally observed with complexes 20a and 122a seem to be related with subtle differences in the ring strain of these metallacyclic intermediates. Finally, we must also mention that complexes $\left[\mathrm{OsCl}_{2}\left(\eta^{6}-p\right.\right.$-cymene $\left.)\left(\mathrm{PPh}_{2} \mathrm{Cl}\right)\right][90]$ and $\left[\mathrm{OsCl}_{2}\left(\eta^{6}-p\right.\right.$ cymene) $\left.\left\{\mathrm{PPh}_{2}\left(\mathrm{NMe}_{2}\right)\right\}\right]$ [91] proved to be useful pre-catalysts for the hydration of $\mathrm{C} \equiv \mathrm{N}$ bonds, since when dissolved in water they evolve into the catalytically active phosphinous acid derivative $\left[\mathrm{OsCl}_{2}\left(\eta^{6}-p\right.\right.$-cymene $\left.)\left(\mathrm{PPh}_{2} \mathrm{OH}\right)\right](\mathbf{1 2 2 b})$ by hydrolysis of the $\mathrm{P}-\mathrm{Cl}$ and $\mathrm{P}-\mathrm{N}$ bonds, respectively.
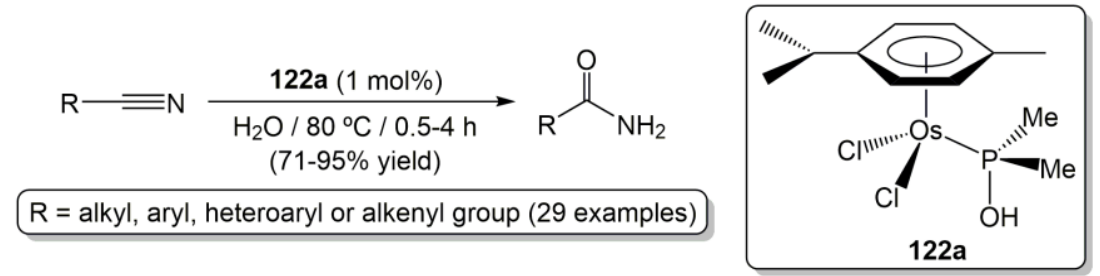

Scheme 44. Catalytic hydration of nitriles employing the osmium(II) complex 122a.

\section{2. $C-H$ bond arylation processes}


The catalytic activation of unreactive $\mathrm{C}\left(\mathrm{sp}^{2}\right)-\mathrm{H}$ bonds is a field of enormous current interest [107]. In this context, the use of low-cost ruthenium-based catalysts has tremendously contributed to the discovery of new $\mathrm{C}-\mathrm{C}$ coupling reactions by directinggroup-assisted $\mathrm{C}\left(\mathrm{sp}^{2}\right)-\mathrm{H}$ activation processes [108], a field in which secondary phosphine oxides has found utility as air- and moisture-stable pre-ligands [109]. Ackermann described the first example of the successful combination of a ruthenium complex with a SPO in a catalytic system for the arylation of 2-phenylpyridine $\mathbf{1 4 8}$ (Scheme 45) [110]. Thus, he found that the association of the ruthenium dimer $\left[\left\{\mathrm{RuCl}(\mu-\mathrm{Cl})\left(\eta^{6}-p \text {-cymene }\right)\right\}_{2}\right](\mathbf{1 8 b})$ with an excess of $\mathrm{Ad}_{2} \mathrm{P}(=\mathrm{O}) \mathrm{H}$ and $\mathrm{K}_{2} \mathrm{CO}_{3}$ was particularly effective for the ortho-diarylation of $\mathbf{1 4 8}$ with different arylchlorides, in $\mathrm{N}$ methylpyrrolidine (NMP) at $120^{\circ} \mathrm{C}$, affording the corresponding products 149 in high yields regardless of the electronic nature or substitution pattern of the $\mathrm{ArCl}$ reagents. In the same work, he also demonstrated the utility of the $18 \mathbf{b} / \mathrm{Ad}_{2} \mathrm{P}(=\mathrm{O}) \mathrm{H}$ combination for the monoarylation of ketimines 150, reactions from which the ketone products 151 were isolated after hydrolytic work-up [110]. As in the precedent case, a good tolerance to functional groups and substitution pattern on the $\mathrm{ArCl}$ partners was observed.

The catalytic system $\mathbf{1 8 b} / \mathrm{Ad}_{2} \mathrm{P}(=\mathrm{O}) \mathrm{H}$ was also effective in the direct arylation of triazole 152 [111] and 2-phenoxypyridine 154 [112] with 4-bromoanisole, affording 153 or a mixture of the mono- and diarylated products 155 and 156, respectively, with yields superior to those obtained when classical phosphines or $N$-heterocyclic carbenes were employed as ligands (Scheme 46). However, we must to indicate that for these particular reactions a slightly higher yield or a better selectivity was observed when $\mathrm{MesCO}_{2} \mathrm{H}\left(\mathrm{Mes}=\right.$ mesityl), instead of $\mathrm{Ad}_{2} \mathrm{P}(=\mathrm{O}) \mathrm{H}$, was used as co-catalyst. 


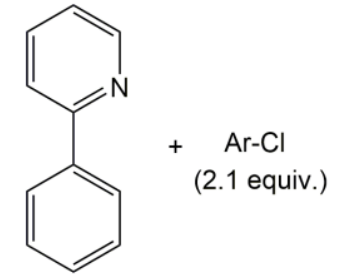

148

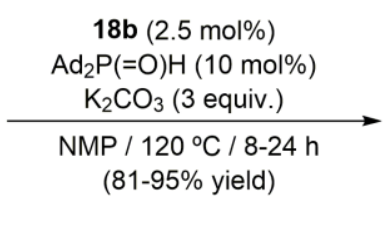

$(81-95 \%$ yield $)$<smiles>Brc1cccc(Br)c1-c1ccccn1</smiles>

149

$\mathrm{Ar}=\mathrm{Ph}, 4-\mathrm{C}_{6} \mathrm{H}_{4} \mathrm{CO}_{2} \mathrm{Et}, 3-\mathrm{C}_{6} \mathrm{H}_{4} \mathrm{CN}, 4-\mathrm{C}_{6} \mathrm{H}_{4} \mathrm{C}(=\mathrm{O}) \mathrm{Me}, 4-\mathrm{C}_{6} \mathrm{H}_{4} \mathrm{OMe}$

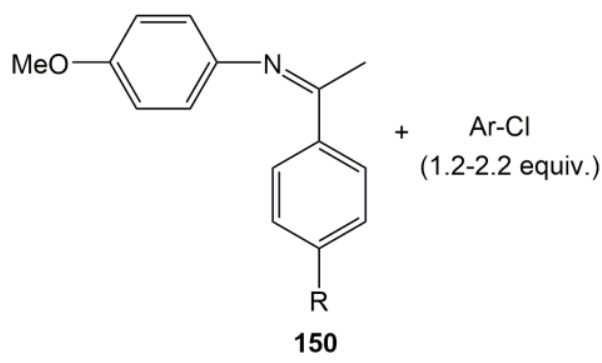

1) $18 \mathrm{~b}(2.5 \mathrm{~mol} \%)$

$\mathrm{Ad}_{2} \mathrm{P}(=\mathrm{O}) \mathrm{H}(10 \mathrm{~mol} \%)$

$\mathrm{K}_{2} \mathrm{CO}_{3}$ (3 equiv.)

$\mathrm{NMP} / 120^{\circ} \mathrm{C} / 16-24 \mathrm{~h}$

2) $1 \mathrm{M} \mathrm{HCl}(\mathrm{aq}) / 3 \mathrm{~h}$

$(54-79 \%$ yield $)$

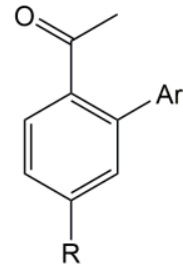

151

$\mathrm{Ar}=4-\mathrm{C}_{6} \mathrm{H}_{4} \mathrm{CF}_{3}, 4-\mathrm{C}_{6} \mathrm{H}_{4} \mathrm{C}(=\mathrm{O}) \mathrm{Me}, 4-\mathrm{C}_{6} \mathrm{H}_{4} \mathrm{CO}_{2} \mathrm{Et}, 3-\mathrm{C}_{6} \mathrm{H}_{4} \mathrm{CO}_{2} \mathrm{Et}, 4-\mathrm{C}_{6} \mathrm{H}_{4} \mathrm{OMe}, 2-\mathrm{C}_{6} \mathrm{H}_{4} \mathrm{Me}$ $\mathrm{R}=\mathrm{H}, \mathrm{Me}, \mathrm{OMe}$ (not all combinations; 10 examples)

Scheme 45. Ru-catalyzed arylation reactions employing a SPO as preligand.<smiles>COc1ccc(Br)cc1</smiles>

152

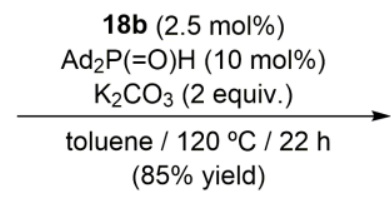

$\mathrm{Ar}=4-\mathrm{C}_{6} \mathrm{H}_{4} \mathrm{OMe}$<smiles>Cc1cccc(Br)c1-n1cc(C(C)(C)C)nn1</smiles>

153<smiles>COc1ccc(Br)cc1</smiles>

154

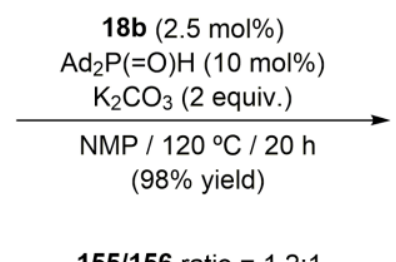

$155 / 156$ ratio $=1.2: 1$<smiles>Brc1ccccc1Oc1ccccn1</smiles>

155<smiles>Brc1cccc(Br)c1Oc1ccccn1</smiles>

156

Scheme 46. Ru-catalyzed arylation reactions of triazole 152 and 2-phenoxypyridine 154.

Ackermann and co-workers extended these studies to the use of aryl-tosylates, instead of the more classical aryl-halides, as the electrophilic coupling partners. In particular, they found that $\mathrm{C}-\mathrm{H}$ functionalization of oxazoline 158 with different 
aromatic tosylates is possible employing dimer $\left[\left\{\mathrm{RuCl}(\mu-\mathrm{Cl})\left(\eta^{6}-p \text {-cymene }\right)\right\}_{2}\right](\mathbf{1 8 b})$ in combination with the sterically hindered diaminophosphine oxide 157 (Scheme 47) [113]. Moreover, in marked contrast with the results depicted in Scheme 45, when this catalytic system was applied to the arylation of 2-phenylpyridine 148 with aryl tosylates a very high selectivity towards the corresponding monoarylated products was observed, with only minor amounts of the diarylated compounds 149 being generated in these reactions [113].

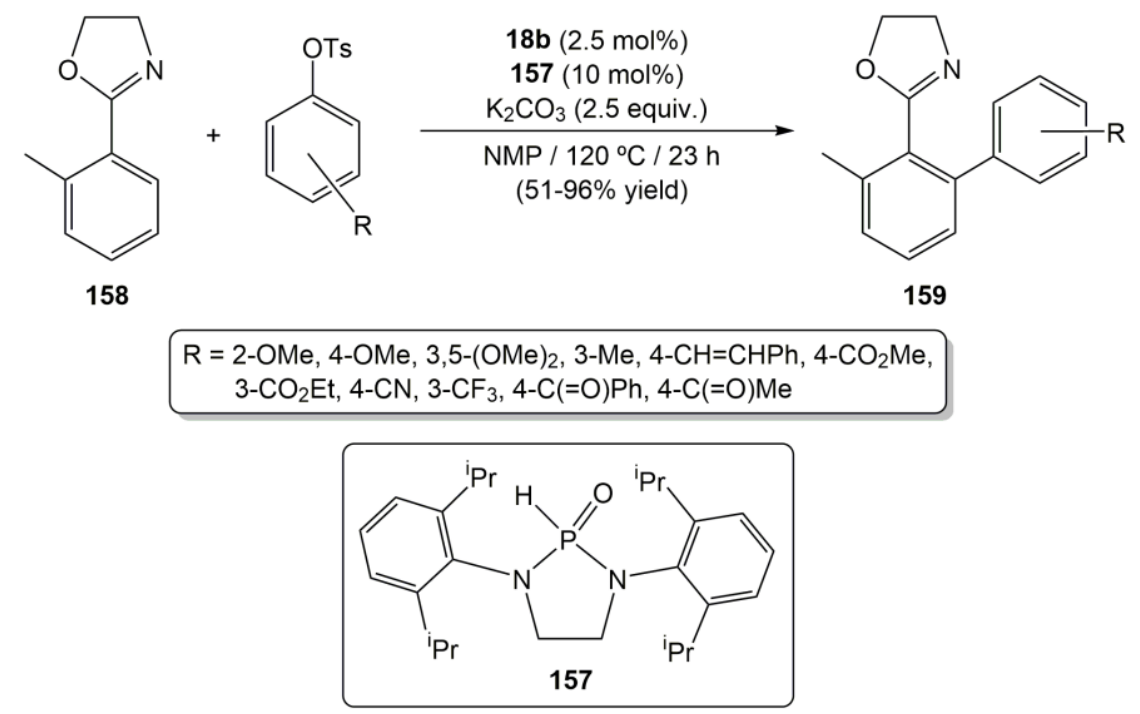

Scheme 47. Ru-catalyzed C-H bond arylation reactions employing tosylates.

As exemplified again with oxazoline 158, the 18b/157 combination was successfully employed in more challenging arylation processes using phenols as the electrophilic reagents (Scheme 48), dehydrative coupling reactions that could be extended to other pronucleophiles such as aryl-pyrazoles and aryl-pyridines [114]. 


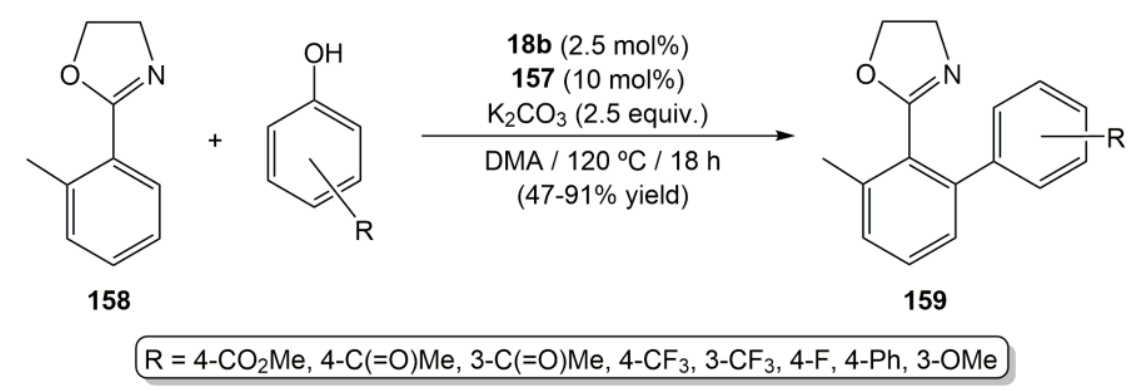

Scheme 48. Ru-catalyzed dehydrative arylation reactions with phenols.

All these directing-group-assisted $\mathrm{C}\left(\mathrm{sp}^{2}\right)-\mathrm{H}$ activation processes involving SPOs as pre-ligands were believed to proceed through a concerted metalation/deprotonation mechanism assisted by a metal-coordinated anionic $\mathrm{R}_{2} \mathrm{PO}^{-}$ligand (Scheme 49) $[111,115]$. Thus, the substrates would react with in situ formed ruthenium intermediates of type $\mathbf{N}$, generating through the transition state $\mathbf{O}$ the key ruthenacyclic species $\mathbf{P}$. Further reaction of $\mathbf{P}$ with the aryl (pseudo)halides would lead to the ortho-arylated products.

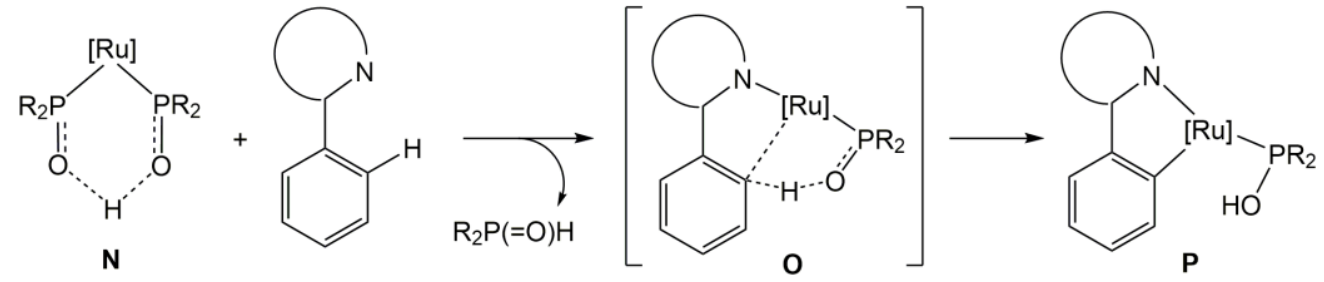

Scheme 49. The role of SPOs pre-ligands in the Ru-catalyzed arylation reactions.

In a more recent study, Ackermann and co-workers also reported on the direct use of well-defined ruthenium(II)-phosphinous acid complexes $\left[\mathrm{RuCl}_{2}\left(\eta^{6}-p\right.\right.$ cymene $\left.)\left(\mathrm{PR}^{1} \mathrm{R}^{2} \mathrm{OH}\right)\right]$ (20c-d,f-g,m-o; see Figure 3) as catalysts for these $\mathrm{C}-\mathrm{H}$ activation processes, which in combination with $\mathrm{K}_{2} \mathrm{CO}_{3}$ showed a remarkable activity [31]. In particular, employing $\left[\mathrm{RuCl}_{2}\left(\eta^{6}-p\right.\right.$-cymene $\left.)\left(\mathrm{P}^{\mathrm{n}} \mathrm{Bu}_{2} \mathrm{OH}\right)\right](\mathbf{2 0 c})$ as catalyst very effective and chemoselective procedures for the arylation of oxazoline 158 with aryl tosylates and 
2-vinyl-pyridines 160 with aryl bromides could be developed, presenting both of them an excellent functional group compatibility (Scheme 50). In addition, DFT calculations on the mechanism of these reactions confirmed the cooperative role of the phosphinous acid ligand, which assists the $\mathrm{C}-\mathrm{H}$ ruthenation step, i.e. the generation of intermediates $\mathbf{P}$ through a transition state of type $\mathbf{O}$ (Scheme 49).

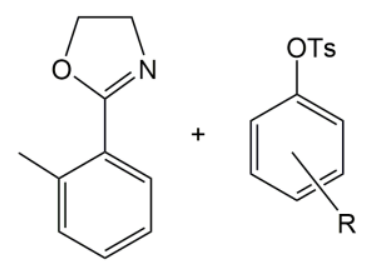

158

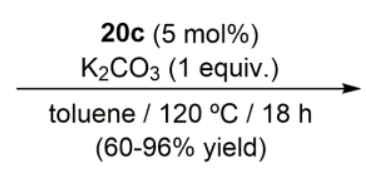

$(60-96 \%$ yield $)$

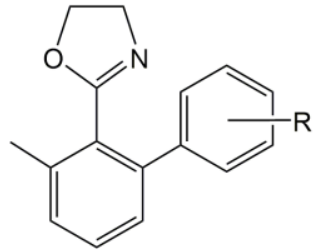

159

$\mathrm{R}=4-\mathrm{Me}, 4-\mathrm{F}, 3-\mathrm{C}(=\mathrm{O}) \mathrm{Me}, 4-\mathrm{C}(=\mathrm{O}) \mathrm{Me}, 4-\mathrm{CO}_{2} \mathrm{Me}, 2-\mathrm{OMe}$
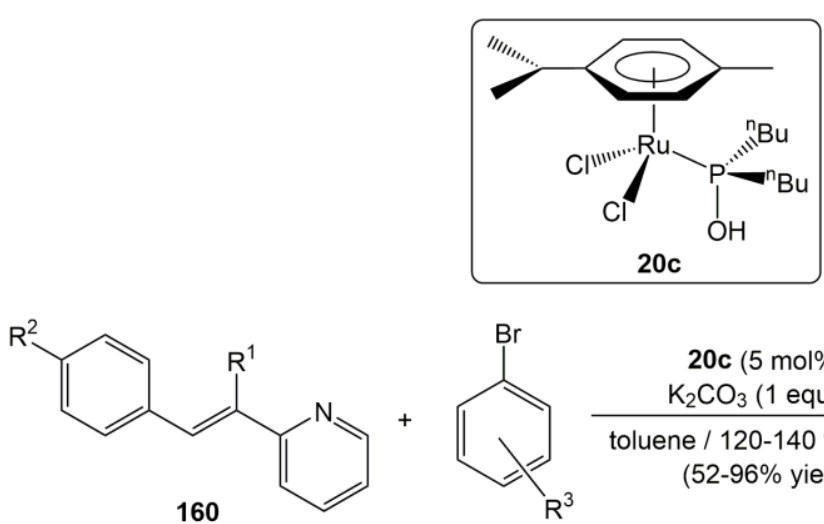

(

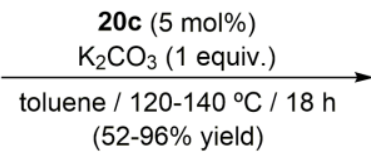<smiles>[R]C(=C(c1ccccc1)c1ccc([R])cc1)c1ccccn1</smiles>

$\mathrm{R}^{3}=\mathrm{H}, 2-\mathrm{OMe}, 3-\mathrm{OMe}, 4-\mathrm{OMe}, 4-\mathrm{Me}, 4-\mathrm{F}, 4-\mathrm{CF}_{3}, 4-\mathrm{NMe}_{2}, 4-\mathrm{CO}_{2} \mathrm{Et}, 4-\mathrm{C}(=\mathrm{O}) \mathrm{Me}$ $\mathrm{R}^{1}=\mathrm{H}, \mathrm{Me} ; \mathrm{R}^{2}=\mathrm{H}, \mathrm{Me}, \mathrm{CF}_{3}$ (not all combinations) (15 examples)

161

Scheme 50. C-H arylation processes catalyzed by the phosphinous acid complex 20c.

More importantly from a synthetic point of view, Ackermann and co-workers also found that the well-defined ruthenium(II)-phosphinous acid complexes $\mathbf{2 0}$ facilitate $\mathrm{C}-\mathrm{H}$ activation reactions of aryl tetrazoles with aryl bromides [31], a process of relevance for potential application in the preparation of a variety of drugs. For this particular transformation $\left[\mathrm{RuCl}_{2}\left(\eta^{6}-p\right.\right.$-cymene $\left.)\left(\mathrm{P}^{\mathrm{t}} \mathrm{BuPhOH}\right)\right]$ (20o) gave the best results, with exceptional tolerance to functional groups, versatility and robustness as exemplified in 
the arylation reactions of the model tetrazole substrate $\mathbf{1 6 2}$, from which a number of arylated products $\mathbf{1 6 3}$ were obtained in high yield (Scheme 51). All these features were further illustrated by the unprecedented direct synthesis of compound 165, a protected form of the antihypertensive drug Valsartan, by coupling 162 with the aryl bromide 164, a transformation that proceeded cleanly and without racemization of the chiral amido ester moiety.<smiles>CC(C)n1nnnc1-c1ccccc1</smiles>

$$
162
$$<smiles>Brc1cccc(I)c1</smiles>

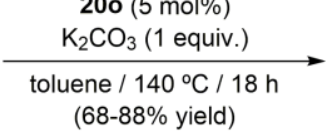

$(68-88 \%$ yield)

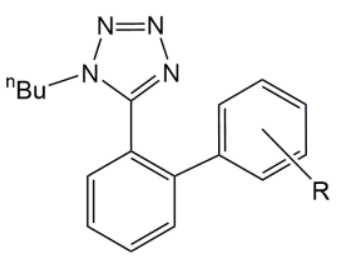

163 $\mathrm{R}=4-\mathrm{CF}_{3}, 4-\mathrm{Cl}, 3,4,5-(\mathrm{OMe})_{3}, 4-\mathrm{NMe}_{2}, 4-\mathrm{CH}_{2} \mathrm{OAc}, 4-\mathrm{CH}_{2} \mathrm{OC}(=\mathrm{O}) \mathrm{Ph}, 4-\mathrm{C}(=\mathrm{O}) \mathrm{Me}$

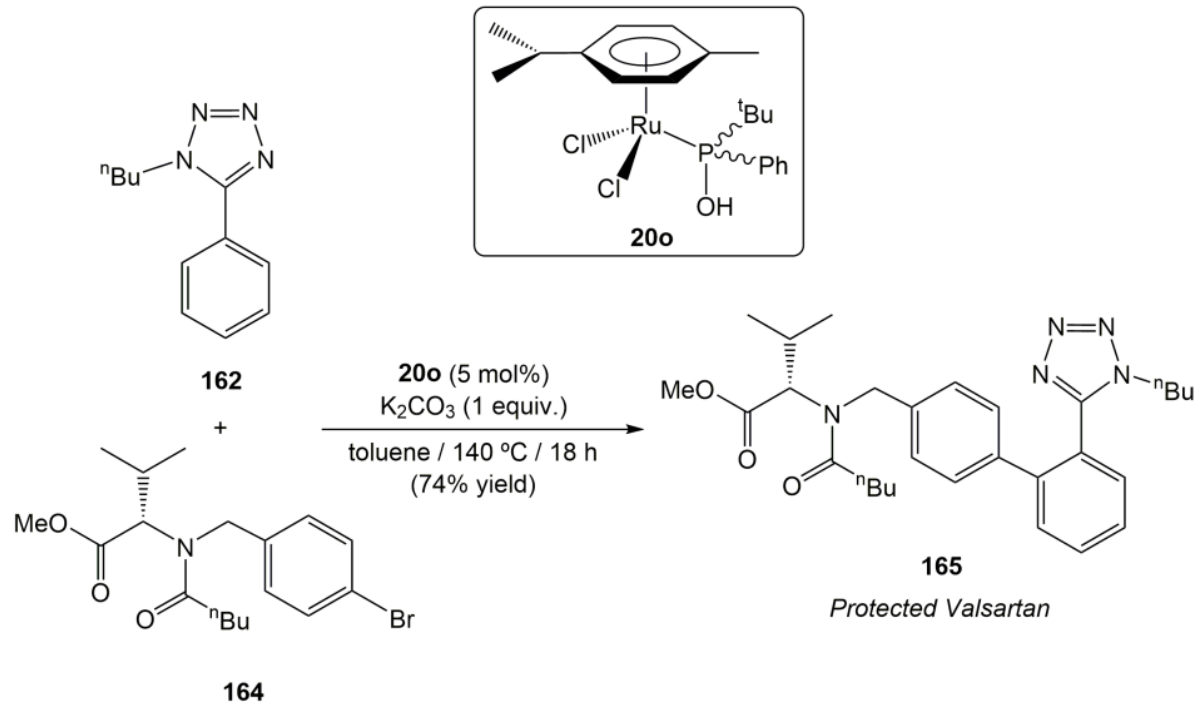

Scheme 51. Ru-catalyzed C-H arylation of tetrazole 162: Access to protected Valtarsan 165.

Additionally, related arylation reactions of 2-phenylpyridine 148 with chlorobenzene employing complexes $\left[\mathrm{RuCl}_{2}\left(\eta^{6}\right.\right.$-p-cymene $\left.)\left(\mathrm{PR}^{1} \mathrm{R}^{2} \mathrm{OH}\right)\right](\mathbf{2 0 a}, \mathbf{e}-\mathbf{g}, \mathbf{k}, \mathbf{n}-\mathbf{q}$; see Figure 3), $\left[\operatorname{RuBr}_{2}\left(\eta^{6}-p\right.\right.$-cymene $\left.)\left(\mathrm{P}^{t} \mathrm{BuPhOH}\right)\right] \quad(\mathbf{2 7 b})$ and $\left[\mathrm{RuI}_{2}\left(\eta^{6}-p\right.\right.$ cymene $\left.)\left(\mathrm{P}^{t} \mathrm{BuPhOH}\right)\right](\mathbf{2 8 b})$ as catalysts were described by Clavier and co-workers [10]. 
Performing the reactions at $80{ }^{\circ} \mathrm{C}$ in NMP with $\mathrm{K}_{2} \mathrm{CO}_{3}$ as the base, complex $\left[\mathrm{RuCl}_{2}\left(\eta^{6}-\right.\right.$ p-cymene $\left.)\left(\mathrm{P}^{t} \mathrm{BuPhOH}\right)\right]$ (20o) containing the bulkier phosphinous acid ligand was identified as the most effective one, leading to the formation of corresponding diarylated product in $89 \%$ yield after $24 \mathrm{~h}$. Interestingly, these well-defined complexes performed in general slightly better than the in situ-generated ones, and the addition of an extra quantity of the corresponding SPO was found to reduce their activity. Additional experiments with complexes $\mathbf{2 0}$ in the presence of different additives allowed also to establish a marked halide dependence of the reaction, being drastically inhibited when $\mathrm{LiCl}$ or ${ }^{\mathrm{n}} \mathrm{Bu} 4 \mathrm{NCl}$ were added to the medium. Similarly, a reduced activity was observed in the presence of $\mathrm{AgBF}_{4}$, suggesting that the two chloride ligands present in complexes $\mathbf{2 0}$ are necessary and play a role in the $\mathrm{C}-\mathrm{H}$ activation process.

\subsection{Hydrogenation reactions}

In 2010 the groups of Pugin and Pfaltz described the preparation of two different families of optically active mixed SPO-phosphine ligands, containing a chiral ferrocenyl backbone 166a-d or a chiral substituent on the SPO unit 167a-c (Figure 16), which were tested in the ruthenium-catalyzed asymmetric hydrogenation of the $\beta$-ketoesters [116]. Although the details given by the authors in this regard were minimal, they commented about quite disparate results from which structure/selectivity relationships could not be established. However, they clearly stated that a catalytic system generated in situ by combining the ruthenium dimer $\left[\left\{\operatorname{RuCl}(\mu-\mathrm{Cl})\left(\eta^{6}-p \text {-cymene }\right)\right\}_{2}\right](\mathbf{1 8 b})$ with the ferrocenyl ligand 166a was able to hydrogenate quantitatively ethyl 3-oxopentanoate with $92 \%$ ee at a S/C ratio of 5000 (reaction performed at room temperature under 1 bar $\mathrm{H}_{2}$ pressure). 


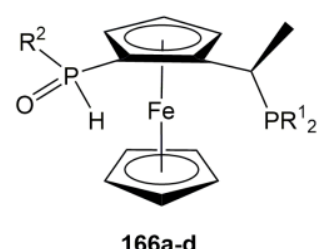

$$
\begin{aligned}
& \mathrm{R}^{1}=\mathrm{Ph}, \mathrm{R}^{2}={ }^{\mathrm{t}} \mathrm{Bu}(\mathbf{a}) \\
& \mathrm{R}^{1}={ }^{\mathrm{t}} \mathrm{Bu}, \mathrm{R}^{2}=\mathrm{Ph}(\mathbf{b}) \\
& \mathrm{R}^{1}=\mathrm{R}^{2}={ }^{\mathrm{t}} \mathrm{Bu}(\mathbf{c}), \mathrm{Ph}(\mathbf{d})
\end{aligned}
$$

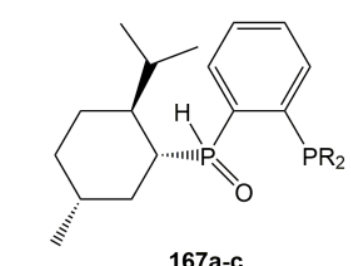

$167 a-c$

$\mathrm{R}=\mathrm{Ph}(\mathbf{a}), 4-\mathrm{C}_{6} \mathrm{H}_{4} \mathrm{Me}(\mathbf{b}), \mathrm{Cy}(\mathbf{c})$

Figure 16. Structure of the optically active ligands 166a-d and 167a-c.

Zhang and co-workers synthesized the octahedral hydride-ruthenium(II) complex 169 by reacting the tridentate SPO ligand 168 with $\left[\mathrm{RuHCl}(\mathrm{CO})\left(\mathrm{PPh}_{3}\right)_{3}\right]$ in refluxing toluene (Scheme 52) [117]. This complex showed a good catalytic activity in the hydrogenation of aldehydes, associated with an excellent selectivity in the case of $\alpha, \beta$ unsaturated aldehydes. DFT calculations suggested that the reaction takes place through an outer-sphere mechanism involving the initial formation of a phosphinous acid dihydride intermediate $\mathbf{Q}$, by hydrogenation of $\mathbf{1 6 9}$, followed by the concerted transfer of one hydride ligand and the $\mathrm{P}-\mathrm{OH}$ proton to the aldehyde (transition state $\mathbf{R}$ ).<smiles>O=P(c1ccccc1)(c1ccccc1)c1ccccc1P</smiles>

168

\section{$\left[\mathrm{RuHCl}(\mathrm{CO})\left(\mathrm{PPh}_{3}\right)_{3}\right]$ (1 equiv.)} (t)luene / reflux

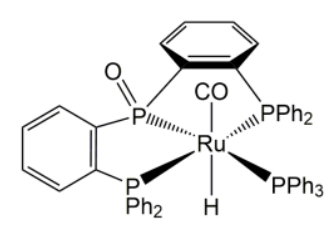

169

$$
\overbrace{\begin{array}{c}
\text { toluene } / 80^{\circ} \mathrm{C} / 18 \mathrm{~h} \\
(85-99 \% \text { yield })
\end{array}}^{\frac{509 \text { bar } \mathrm{H}_{2}}{(8.005-0.02 \mathrm{~mol} \%)}}
$$

$R=$ alkyl, aryl or alkenyl group (12 examples)

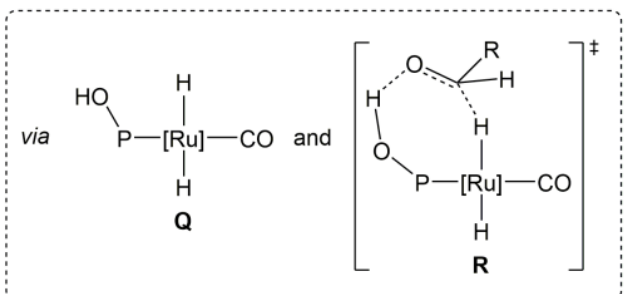

Scheme 52. Hydrogenation of aldehydes employing complex 169 as catalyst. 
In another vein, SPOs are gaining increasing attention as pre-ligands for the stabilization of metal nanoparticles (NPs) [118]. In this context, van Leeuwen and coworkers reported the use of a variety of SPOs with different electronic and steric properties for the stabilization of ruthenium NPs generated by decomposition of the organometallic precursor $[\mathrm{Ru}(\mathrm{COD})(\mathrm{COT})](\mathrm{COT}=1,3,5,7$-cyclooctatetraene $)$ in the presence of $\mathrm{H}_{2(\mathrm{~g})}$ [119]. A narrow particle size distribution and the smallest amount of agglomeration were obtained with $\mathrm{Ph}_{2} \mathrm{P}(=\mathrm{O}) \mathrm{H}$ (size range of the RuNPs of 1-2 nm), which was supposed to coordinate the ruthenium atoms as the corresponding $\mathrm{PPh}_{2} \mathrm{OH}$ tautomer. In addition, these RuNPs displayed a remarkable activity in hydrogenation reactions of aromatic compounds at very low catalyst loadings (a representative example is given in Scheme 53).

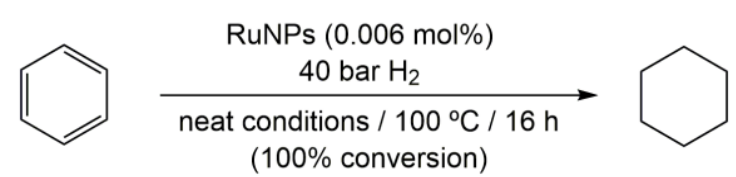

Scheme 53. Benzene to cyclohexane hydrogenation catalyzed by $\mathrm{PPh}_{2} \mathrm{OH}$-stabilized RuNPs.

\subsection{Other catalytic transformations}

The synthetic usefulness of the octahedral bis(phosphinous acid)-ruthenium(II) complexes $\left[\mathrm{RuCl}_{2}(\mathrm{CO})_{2}\left(\mathrm{PR}^{1} \mathrm{R}^{2} \mathrm{OH}\right)_{2}\right]$ (38 in Scheme 7) was evaluated for the cycloisomerization of arenynes using compound $\mathbf{1 7 0}$ as model substrate (Scheme 54) [37]. Thus, while control experiments showed that the dimeric precursor $[\{\operatorname{RuCl}(\mu-$ $\left.\mathrm{Cl})(\mathrm{CO})_{3}\right\}_{2}$ ] (36) in combination with AgOTf is completely ineffective in this transformation (only traces of $\mathbf{1 7 1}$ were formed after $3 \mathrm{~h}$ with a Ru loading of 16 mol\%), complexes 38 proved to be catalytically active at r.t. generating the cycloisomerized 
product $\mathbf{1 7 1}$ in a selective manner. In particular, the best results were obtained with those complexes containing the more electron rich phosphinous acid ligands, such as $\left[\mathrm{RuCl}_{2}(\mathrm{CO})_{2}\left(\mathrm{PCy}_{2} \mathrm{OH}\right)_{2}\right]$ (38e). Full conversion was reached after $0.5 \mathrm{~h}$ employing 16 mol\% of this catalyst. More importantly, the use of $\mathbf{3 8 e}$ allowed to reduce significantly the catalyst loading to only $2 \mathrm{~mol} \%$, with only a slight increase in the reaction time (100\% conversion after 8 h). The cycloisomerization of the less activated arenyne $\mathbf{1 7 2}$ with complexes 38c-f was also explored, the reaction requiring in this case of longer times and thermal activation $\left(80^{\circ} \mathrm{C}\right)$ (Scheme 54). Preferential formation of isomer $\mathbf{1 7 3}$ vs 174 was systematically observed regardless of the catalyst employed, with compounds $\left[\mathrm{RuCl}_{2}(\mathrm{CO})_{2}\left(\mathrm{PPh}^{\mathrm{t} B u O H}\right)_{2}\right] \quad(\mathbf{3 8 c})$ and $\quad\left[\mathrm{RuCl}_{2}(\mathrm{CO})_{2}\left(\mathrm{PPh}_{2} \mathrm{OH}\right)_{2}\right] \quad(\mathbf{3 8 f})$ showing in this case the best performances $(99 \%$ conversion after $24 \mathrm{~h}$ with a $\mathrm{Ru}$ loading of $5 \mathrm{~mol} \%)$.<smiles>CC#CCC(Cc1cc(OC)cc(OC)c1)(C(=O)OCC)C(=O)OCC</smiles>

170

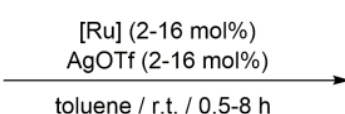

toluene / r.t. / 0.5-8 h

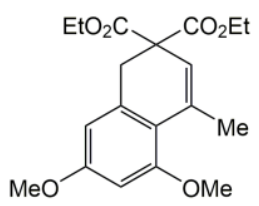

171

\begin{tabular}{llll}
\multicolumn{1}{c}{$[\mathrm{Ru}]$} & loading & time & conversion \\
\hline$\left[\mathrm{RuCl}_{2}(\mathrm{CO})_{2}\left(\mathrm{PPh}^{\dagger} \mathrm{BuOH}\right)_{2}\right](38 \mathrm{c})$ & $16 \mathrm{~mol} \%$ & $1 \mathrm{~h}$ & $50 \%$ \\
{$\left[\mathrm{RuCl}_{2}(\mathrm{CO})_{2}(\mathrm{PPhCyOH})_{2}\right](38 \mathrm{~d})$} & $16 \mathrm{~mol} \%$ & $1 \mathrm{~h}$ & $90 \%$ \\
{$\left[\mathrm{RuCl}_{2}(\mathrm{CO})_{2}\left(\mathrm{PCy}{ }_{2} \mathrm{OH}\right)_{2}\right](38 \mathrm{e})$} & $16 \mathrm{~mol} \%$ & $0.5 \mathrm{~h}$ & $100 \%$ \\
{$\left[\mathrm{RuCl}_{2}(\mathrm{CO})_{2}\left(\mathrm{PPh}_{2} \mathrm{OH}\right)_{2}\right](38 \mathrm{f})$} & $16 \mathrm{~mol} \%$ & $1 \mathrm{~h}$ & $83 \%$ \\
{$\left[\mathrm{RuCl}_{2}(\mathrm{CO})_{2}\left\{\mathrm{P}\left(4-\mathrm{C}_{6} \mathrm{H}_{4} \mathrm{~F}\right)_{2} \mathrm{OH}\right\}_{2}\right](\mathbf{3 8 g})$} & $16 \mathrm{~mol} \%$ & $3 \mathrm{~h}$ & $64 \%$ \\
{$\left[\mathrm{RuCl}_{2}(\mathrm{CO})_{2}\left(\mathrm{PCy} \mathrm{OH}_{2}\right](\mathbf{3 8 e})\right.$} & $8 \mathrm{~mol} \%$ & $1 \mathrm{~h}$ & $100 \%$ \\
{$\left[\mathrm{RuCl}_{2}(\mathrm{CO})_{2}\left(\mathrm{PCy} \mathrm{PH}_{2}\right](\mathbf{3 8 e})\right.$} & $2 \mathrm{~mol} \%$ & $8 \mathrm{~h}$ & $100 \%$
\end{tabular}

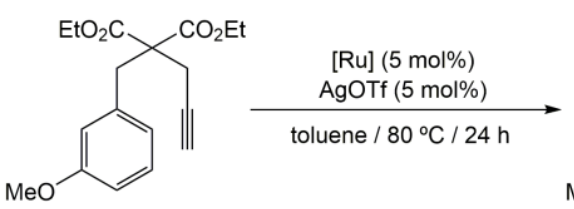

172

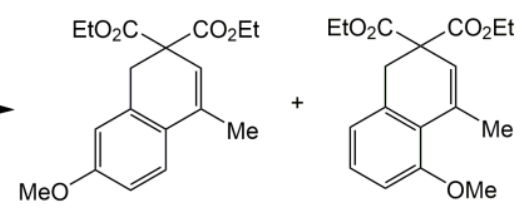

173
174

\begin{tabular}{ccc}
{$[\mathrm{Ru}]$} & conversion & $\mathbf{1 7 3 / 1 7 4}$ ratio \\
\hline$\left[\mathrm{RuCl}_{2}(\mathrm{CO})_{2}\left(\mathrm{PPh}^{\mathrm{t}} \mathrm{BuOH}\right)_{2}\right](\mathbf{3 8 c})$ & $99 \%$ & $97: 3$ \\
{$\left[\mathrm{RuCl}_{2}(\mathrm{CO})_{2}(\mathrm{PPhCyOH})_{2}\right](\mathbf{3 8 d})$} & $45 \%$ & $95: 5$ \\
{$\left[\mathrm{RuCl}_{2}(\mathrm{CO})_{2}\left(\mathrm{PCy}{ }_{2} \mathrm{OH}\right)_{2}\right](\mathbf{3 8 e})$} & $35 \%$ & $96: 4$ \\
{$\left[\mathrm{RuCl}_{2}(\mathrm{CO})_{2}\left(\mathrm{PPh}_{2} \mathrm{OH}\right)_{2}\right](\mathbf{3 8 f})$} & $99 \%$ & $97: 3$
\end{tabular}

Scheme 54. Catalytic cycloisomerization of the arenynes $\mathbf{1 7 0}$ and 172. 
A catalytic system composed of the functionalized $\left(\eta^{6}\right.$-arene)-ruthenium(II) complex $\left[\mathrm{RuCl}_{2}\left(\eta^{6}-\mathrm{C}_{6} \mathrm{H}_{5} \mathrm{CH}_{2} \mathrm{CH}_{2} \mathrm{CH}_{2} \mathrm{OH}\right)\left\{\mathrm{P}(\mathrm{OEt})_{3}\right\}\right]$ (175) and $\mathrm{NaOH}$ was found to promote tandem isomerization/Claisen rearrangement reactions of diallyl ethers $\mathbf{1 7 6}$ in water, allowing the high yield formation of different $\gamma, \delta$-unsaturated aldehydes $\mathbf{1 7 7}$ (Scheme 55) [120].
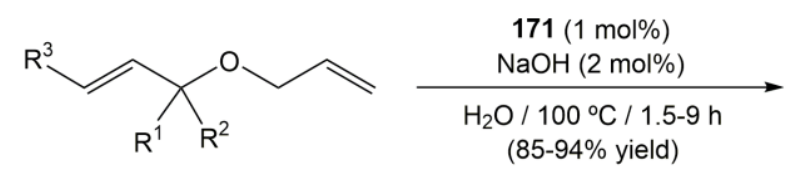<smiles>[R]C([R])=CC([R])C(C)C=O</smiles>

176
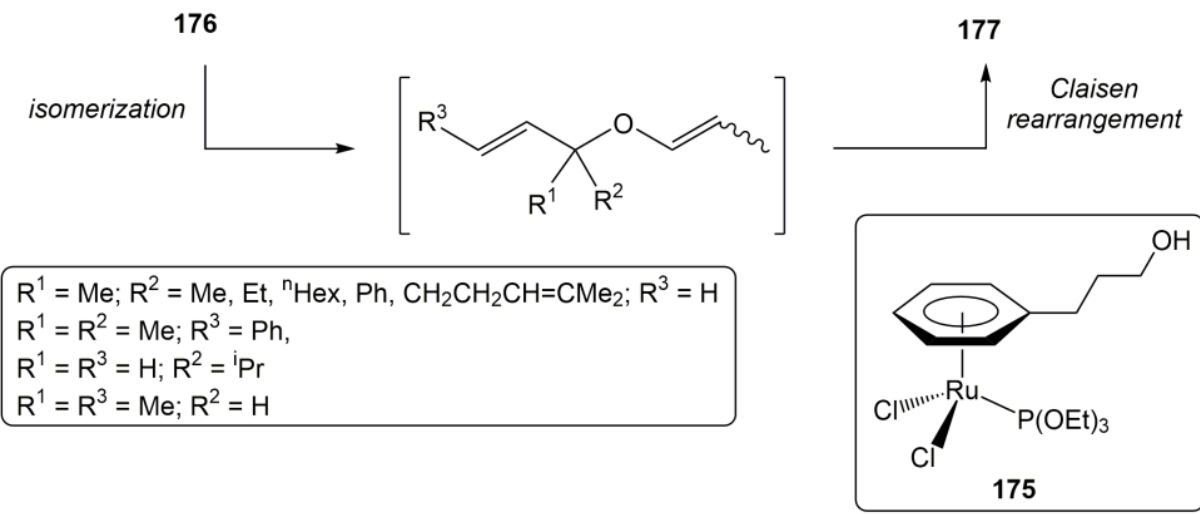

Scheme 55. Ru-catalyzed tandem isomerization/Claisen rearrangement of diallyl ethers $\mathbf{1 7 6}$.<smiles>[R]C=CC([R])([R])OC=CCOC([R])([R])C=CCOC([R])([R])C=C[R]</smiles>

Scheme 56. The role played by the in situ generated $\mathrm{P}(\mathrm{OEt})_{2} \mathrm{OH}$ ligand in the $\mathrm{Ru}$-catalyzed tandem isomerization/Claisen rearrangement of diallyl ethers $\mathbf{1 7 6}$. 
Mechanistic investigations on this tandem reaction indicated that, in aqueous $\mathrm{NaOH}$ solution, the phosphite $\mathrm{P}(\mathrm{OEt})_{3}$ ligand in complex 175 readily undergoes hydrolysis generating ruthenium species in which a $\mathrm{P}(\mathrm{OEt})_{2} \mathrm{OH}$ unit is coordinated to the metal [120]. In addition, a cooperative effect of $\mathrm{P}(\mathrm{OEt})_{2} \mathrm{OH}$ in the initial isomerization step was proposed, facilitating the generation of the allyl vinyl ether intermediates $\mathbf{S}$ (Scheme 56).

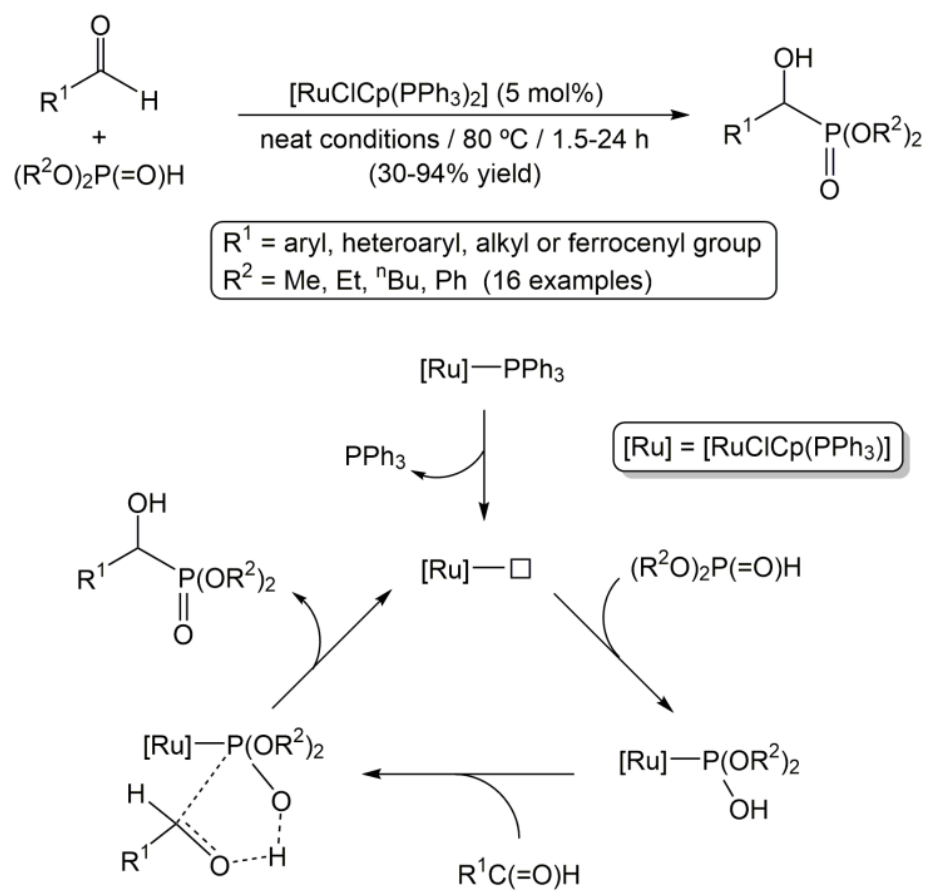

Scheme 57. Ruthenium-catalyzed hydrophosphonylation of aldehydes.

Finally, we would like to mention that very recently Fernandes and co-workers developed a very effective procedure for the hydrophosphonylation of aldehydes employing the cyclopentadienyl-ruthenium(II) complex $\left[\mathrm{RuClCp}\left(\mathrm{PPh}_{3}\right)_{2}\right]$ as catalyst (Scheme 57) [121]. The reactions, which were performed at $80{ }^{\circ} \mathrm{C}$ with $5 \mathrm{~mol} \%$ of this complex, and under solvent-free conditions, afforded the corresponding $\alpha$ hydroxyphosphonate products in moderate to good yields with a very high 
chemoselectivity. Of interest in the context of this review article is the fact that DFT calculations on the mechanism indicated that the reactions proceed through the initial formation of intermediates $\left[\mathrm{RuClCp}\left(\mathrm{PPh}_{3}\right)\left\{\mathrm{P}\left(\mathrm{OR}^{2}\right)_{2} \mathrm{OH}\right\}\right]$, in which the phosphite tautomer coordinated to the $\mathrm{Ru}(\mathrm{II})$ center subsequently reacts with the aldehyde to generate the $\alpha$-hydroxyphosphonate products.

\section{Conclusions and outlook}

The use of unstable phosphinous acids as auxiliary $P$-donor ligands in homogeneous catalysis has received considerable attention in the last years. A large number of transition-metal complexes, pre-formed or generated in situ by combining a metal precursor with a secondary phosphine oxide (SPO) pre-ligand, have found application as catalysts in different organic transformations. In this review article we have discussed the chemistry of Group 8 metal complexes containing phosphinous acids and related $\mathrm{P}-\mathrm{OH}$ ligands, including the different synthetic approaches used to obtain them, their reactivity and their implication in catalysis. The results discussed herein exemplify the versatility and enormous potential offered by this type of ligands in coordination/organometallic chemistry and homogeneous catalysis. In this latter field stands out the non-innocent role played by $\mathrm{OH}$ group in the catalytic hydration of

nitriles and the functionalization of unreactive $\mathrm{C}-\mathrm{H}$ bonds, which cooperates with the metal in the activation of the substrates. Taking into account that the concept of "bifunctional catalysis" is nowadays one of the most promising tools for the design of more efficient and selective catalysts, it is expected that in the coming years new processes making use of this type of cooperative ligands will come to light.

\section{Acknowledgements}


We are indebted to the Spanish MINECO (Project CTQ2016-75986-P) and the Gobierno del Principado de Asturias (Project GRUPIN14-006) for financial support. D.E. thanks Gobierno del Principado de Asturias and the European Union for the award of a postdoctoral fellowship (Clarín-COFUND program). The "Metals and Water" network (REDESMA) is also acknowledged.

\section{References}

[1] See, for example: (a) P. C. J. Kamer, P. W. N. M. van Leeuwen (Eds.), Phosphorus(III) Ligands in Homogeneous Catalysis: Design and Synthesis, John Wiley \& Sons, Chichester, 2012; (b) A. Börner (Ed.), Phosphorus Ligands in Asymmetric Catalysis: Synthesis and Applications, Wiley-VCH, Weinheim, 2008.

[2] See, for example: N. Fey, A. G. Orpen, J. N. Harvey, Coord. Chem. Rev. 253 (2009) 704-722 and references cited therein.

[3] See, for example: D. E. C. Corbrigde, in Phosphorus: An Outline of its Chemistry, Biochemistry and Uses (5 ${ }^{\text {th }}$ Ed.), Elsevier, Amsterdam, 1995, p. 336.

[4] See, for example: (a) J. E. Griffiths, A. B. Burg, J. Am. Chem. Soc. 82 (1960) 1507-1508; (b) B. Hoge, S. Neufeind, S. Hettel, W. Wiebe, C. Thösen, J. Organomet. Chem. 690 (2005) 2382-2387; (c) B. Hoge, P. Garcia, H. Willner, H. Oberhammer, Chem. Eur. J. 12 (2006) 3567-3574; (d) Y. V. Babin, Y. A. Ustynyuk, Russ. J. Phys. Chem. A 81 (2007) 1810-1819; (e) Y. A. Ustynyuk, Y. V. Babin, Russ. J. Gen. Chem. 78 (2008) 822-832; (f) Y. V. Babin, A. V. Pisyazhnyuk, Y. A. Ustynyuk, Russ. J. Phys. Chem. A 82 (2008) 94-100; (g) B. Hoge, J. Bader, H. Beckers, Y. S. Kim, R. Eujen, H. Willner, N. Ignatiev, Chem. Eur. J. 15 (2009) 3567-3576; (h) A. Christiansen, C. Li, M. Garland, D. Selent, 
R. Ludwig, A. Spannenberg, W. Baumann, R. Franke, A. Börner, Eur. J. Org. Chem. (2010) 2733-2741; (i) B. Kurscheid, W. Wiebe, B. Neumann, H.-G, Stammler, B. Hoge, Eur. J. Inorg. Chem. (2011) 5523-5529; (j) H. Tavakol, F. Keshavarzipour, Heteroatom Chem. 27 (2016) 210-220.

[5] J. Chatt, B. T. Heaton, J. Chem. Soc. A (1968) 2745-2757.

[6] For review articles covering partially this field, see: (a) D. M. Roundhill, R. P. Sperline, W. B. Beaulieu, Coord. Chem. Rev. 26 (1978) 263-279; (b) B. Walther, Coord. Chem. Rev. 60 (1984) 67-105; (c) T. Appleby, J. D. Woollins, Coord. Chem. Rev. 235 (2002) 121-140; (d) P. Sutra, A. Igau, Coord. Chem. Rev. 308 (2016) 97-116.

[7] (a) N. V. Dubrovina, A. Börner, Angew. Chem. Int. Ed. 43 (2004) 5883-5886; (b) L. Ackermann, Synthesis (2006) 1557-1571; (c) T. M. Shaikh, C.-M. Weng, F.-E. Hong, Coord. Chem. Rev. 256 (2012) 771-803; (d) T. Achard, Chimia 70 (2016) 8-19.

[8] T. Ikariya, M. Shibasaki (Eds.), Bifunctional Molecular Catalysis, Springer, Berlin, 2011.

[9] (a) D. Martin, D. Moraleda, T. Achard, L. Giordano, G. Buono, Chem. Eur. J. 17 (2011) 12729-12740; (b) D. G. Gusev, Organometallics 28 (2009) 763-770.

[10] L. V. Graux, M. Giorgi, G. Buono, H. Clavier, Dalton Trans. 45 (2016) 64916502.

[11] H. Clavier, S. P. Nolan, Chem. Commun. 46 (2010) 841-861.

[12] J. M. Jenkins, T. J. Huttemann, J. G. Verkade, Advances in Chemistry 62 (1967) 604-615.

[13] P. M. Treichel, L. D. Rosenhein, Inorg. Chem. 20 (1981) 1539-1545. 
[14] H. Brunner, R. Eder, B. Hammer, U. Klement, J. Organomet. Chem. 394 (1990) $555-567$.

[15] M. Di Vaira, M. Peruzzini, S. S. Costantini, P. Stoppioni, J. Organomet. Chem. 695 (2010) 816-820.

[16] I. de los Rios, J.-R. Hamon, P. Hamon, C. Lapinte, L. Toupet, A. Romerosa, M. Peruzzini, Angew. Chem. Int. Ed. 40 (2001) 3910-3912.

[17] For general reviews on the synthesis and reactivity of late-transition metal complexes containing $\mathrm{P}_{4}$ as ligand, see: (a) M. Caporali, L. Gonsalvi, A. Rossin, M. Peruzzini, Chem. Rev. 110 (2010) 4178-4235; (b) M. Di Vaira, M. Peruzzini, P. Stoppioni, C. R. Chimie 13 (2010) 935-942.

[18] A. Grohmann, Dalton Trans. 39 (2010) 1432-1440 and references cited therein.

[19] S. W. Kohl, F. W. Heinemann, M. Hummert, W. Bauer, A. Grohmann, Dalton Trans. (2006) 5583-5592.

[20] M. A. Alvarez, M. E. García, D. García-Vivó, A. Ramos, M. A. Ruiz, Inorg. Chem. 51 (2012) 3698-3706.

[21] M. A. Alvarez, M. E. García, R. González, M. A. Ruiz, Dalton Trans. 41 (2012) 14498-14513.

[22] H. Schäfer, Angew. Chem. Int. Ed. Engl. 20 (1981) 608-610.

[23] B. Deppisch, H. Schäfer, Acta Cryst. Sect. C 39 (1983) 975-976.

[24] V. I. Galkin, I. V. Galkina, K. Al Kurdi, B. V. Denisov, R. A. Cherkasov, Metalloorg. Khim. 3 (1990) 1429-1431.

[25] I. V. Galkina, G. M. Saakyan, V. I. Galkin, R. A. Cherkasov, Russ. J. Gen. Chem. 63 (1993) 2221-2223.

[26] E. Tomás-Mendivil, V. Cadierno, M. I. Menéndez, R. López, Chem. Eur. J. 21 (2015) 16874-16886. 
[27] T. Oshiki, M. Muranaka, PCT Int. Appl. WO 2012/017966.

[28] R. Krafczyk, H. Thönnessen, P. G. Jones, R. Schmutzler, J. Fluorine Chem. 83 (1997) 159-166.

[29] S. M. M. Knapp, T. J. Sherbow, R. B. Yelle, J. J. Juliette, D. R. Tyler, Organometallics 32 (2013) 3744-3752.

[30] E. Tomás-Mendivil, L. Menéndez-Rodríguez, J. Francos, P. Crochet, V. Cadierno, RSC Adv. 4 (2014) 63466-63474.

[31] D. Zell, S. Warratz, D. Gelman, S. J. Garden, L. Ackermann, Chem. Eur. J. 22 (2016) 1248-1252.

[32] R. González-Fernández, P. J. González-Liste, J. Borge, P. Crochet, V. Cadierno, Catal. Sci. Technol. 6 (2016) 4398-4409.

[33] W. Kläui, E. Buchholz, Inorg. Chem. 27 (1988) 3500-3506.

[34] F. D. Calvo, V. Mirabello, M. Caporali, W. Oberhauser, K. Raltchev, K. Karaghisoff, M. Peruzzini, Dalton Trans. 45 (2016) 2284-2293.

[35] W. Kläui, E. Buchholz, Angew. Chem. Int. Ed. Engl. 27 (1988) 580-581.

[36] M. Scotti, M. Valderrama, J. Cuevas, A. Miranda, Bol. Soc. Chil. Quím. 36 (1991) 57-61.

[37] L. V. Graux, M. Giorgi, G. Buono, H. Clavier, Organometallics 34 (2015) 18641871.

[38] D. N. Akbayeva, M. Di Vaira, S. S. Costantini, M. Peruzzini, P. Stoppioni, Dalton Trans. (2006) 389-395.

[39] M. Di Vaira, M. Peruzzini, S. S. Costantini, P. Stoppioni, J. Organomet. Chem. 691 (2006) 3931-3937.

[40] M. Caporali, L. Gonsalvi, R. Kagirov, V. Mirabello, M. Peruzzini, O. Sinyashin, P. Stoppioni, D. Yakhvarov, J. Organomet. Chem. 714 (2012) 67-73. 
[41] M. Caporali, F. D. Calvo, C. Bazzicalupi, S. S. Costantini, M. Peruzzini, J. Organomet. Chem. 859 (2018) 68-74.

[42] F. Centofanti, R. W. Parry, Inorg. Chem. 7 (1968) 1005-1009.

[43] D. Yakhvarov, M. Caporali, L. Gonsalvi, S. Latypov, V. Mirabello, I. Rizvanov, O. Sinyashin, P. Stoppioni, M. Peruzzini, Angew. Chem. Int. Ed. 50 (2011) 5370-5373.

[44] G. Manca, M. Caporali, A. Ienco, M. Peruzzini, C. Mealli, J. Organomet. Chem. $760(2014) 177-185$.

[45] T. Rüther, U. Englert, U. Koelle, Inorg. Chem. 37 (1998) 4265-4271.

[46] R. L. Sernaglia, D. W. Franco, Inorg. Chem. 28 (1989) 3485-3489.

[47] D. R. Truzzi, A. G. Ferreira, S. C. da Silva, E. E. Castellano, F. d. C. A. Lima, D. W. Franco, Dalton Trans. 40 (2011) 12917-12925.

[48] D. R. Truzzi, E. E. Castellano, D. W. Franco, Polyhedron 124 (2017) 184-190.

[49] D. R. Truzzi, D. W. Franco, Inorg. Chim. Acta 421 (2014) 74-79.

[50] D. R. Truzzi, D. W. Franco, Polyhedron 81 (2014) 238-244.

[51] G. Metzker, J. C. Toledo Jr., F. C. A. Lima, A. Magalhães, D. R. Cardoso, D. W. Franco, J. Braz. Chem. Soc. 21 (2010) 1266-1273.

[52] K. S. Feichner, V. H. Gessner, Chem. Commun. 54 (2018) 6540-6553, and references cited therein.

[53] J. Weismann, L. T. Scharf, V. H. Gessner, Organometallics 35 (2016) 25072515.

[54] E. Y. Y. Chan, Q.-F. Zhang, Y.-K. Sau, S. M. F. Lo, H. H. Y. Sung, I. D. Williams, R. K. Haynes, W.-H. Leung, Inorg. Chem. 43 (2004) 4921-4926.

[55] A. Gallen, S. Orgué, G. Muller, E. C. Escudero-Adán, A. Riera, X. Verdaguer, A. Grabulosa, Dalton Trans. 47 (2018) 5366-5379. 
[56] R. O. Gould, C. L. Jones, W. J. Sime, T. A. Stephenson, J. Chem. Soc., Dalton Trans. (1977) 669-672.

[57] T. G. Southern, P. H. Dixneuf, J.-Y. Le Marouille, D. Grandjean, Inorg. Chem. 18 (1979) 2987-2991.

[58] H.-L. Ji, J. H. Nelson, A. D. Cian, J. Fischer, Organometallics 11 (1992) 16181626.

[59] H. Salem, L. J. Shimon, Y. Diskin-Posner, G. Leitus, Y. Ben-David, D. Milstein, Organometallics 28 (2009) 4791-4806.

[60] D. Hesek, G. A. Hembury, M. G. B. Drew, S. Tanaguchi, Y. Inoue, J. Am. Chem. Soc. 122 (2000) 10236-10237.

[61] J. Coetzee, G. R. Eastham, A. M. Z. Slawin, D. J. Cole-Hamilton, Dalton Trans. 43 (2014) 3479-3491.

[62] C. M. Nagaraja, M. Nethaji, B. R. Jagirdar, Inorg. Chem. Commun. 7 (2004) 654-656.

[63] C. M. Nagaraja, M. Nethaji, B. R. Jagirdar, Inorg. Chem. 44 (2005) 4145-4147.

[64] C. M. Nagaraja, K. S. Naidu, M. Nethaji, B. R. Jagirdar, Inorg. Chim. Acta 363 (2010) 3017-3022.

[65] C. M. Nagaraja, P. Parameswaran, E. D. Jemmis, B. R. Jagirdar, J. Am. Chem. Soc. 129 (2007) 5587-5596.

[66] T. J. Geldbach, P. S. Pregosin, A. Albinati, Organometallics 22 (2003) 14431451.

[67] R. Tribó, J. Pons, R. Yáñez, J. F. Piniella, A. Alvarez-Larena, J. Ros, Inorg. Chem. Commun. 3 (2000) 545-549.

[68] R.-M. Tribó, J. Ros, J. Pons, R. Yáñez, A. Álvarez-Larena, J.-F. Piniella, J. Organomet. Chem. 676 (2003) 38-42. 
[69] S. Pavlik, K. Mereiter, M. Puchberger, K. Kirchner, Organometallics 24 (2005) $3561-3575$.

[70] A. K. Pandiakumar, A. G. Samuelson, J. Chem. Sci. 127 (2015) 1329-1338.

[71] I. W. Robertson, T. A. Stephenson, Inorg. Chim. Acta 45 (1980) L215-L216.

[72] M. Di Vaira, P. Frediani, S. S. Costantini, M. Peruzzini, P. Stoppioni, Dalton Trans. (2005) 2234-2236.

[73] P. Barbaro, M. Di Vaira, M. Peruzzini, S. S. Costantini, P. Stoppioni, Chem. Eur. J. 13 (2007) 6682-6690.

[74] P. Barbaro, M. Di Vaira, M. Peruzzini, S. S. Costantini, P. Stoppioni, Angew. Chem. Int. Ed. 47 (2008) 4425-4427.

[75] P. Barbaro, M. Di Vaira, M. Peruzzini, S. S. Costantini, P. Stoppioni, Inorg. Chem. 48 (2009) 1091-1096.

[76] C. J. den Reijer, M. Wörle, P. S. Pregosin, Organometallics 19 (2000) 309-316.

[77] T. J. Geldbach, F. Breher, V. Gramlich, P. G. A. Kumar, P. S. Pregosin, Inorg. Chem. 43 (2004) 1920-1928.

[78] T. J. Geldbach, P. S. Pregosin, Eur. J. Inorg. Chem. (2002) 1907-1918.

[79] T. J. Geldbach, D. Drago, P. S. Pregosin, Chem. Commun. (2000) 1629-1630.

[80] T. J. Geldbach, P. S. Pregosin, M. Bassetti, Organometallics 20 (2001) 29902997.

[81] T. J. Geldbach, P. S. Pregosin, A. Albinati, F. Rominger, Organometallics 20 (2001) 1932-1938.

[82] T. J. Geldbach, D. Drago, P. S. Pregosin, J. Organomet. Chem. 643-644 (2002) 214-222.

[83] T. J. Geldbach, C. J. den Reijer, M. Wörle, P. S. Pregosin, Inorg. Chim. Acta $330(2002)$ 155-160. 
[84] V. Cadierno, J. Díez, J. García-Álvarez, J. Gimeno, Organometallics 23 (2004) $3425-3436$.

[85] R. Sylvain, L. Vendier, C. Bijani, A. Santoro, F. Puntoriero, S. Campagna, P. Sutra, A. Igau, New J. Chem. 37 (2013) 3543-3548.

[86] R. Torres-Lubián, M. J. Rosales-Hoz, A. M. Arif, R. D. Ernst, M. A. PazSandoval, J. Organomet. Chem. 585 (1999) 68-82.

[87] E. Tomás-Mendivil, F. J. Suárez, J. Díez, V. Cadierno, Chem. Commun. 50 (2014) 9661-9664.

[88] E. Tomás-Mendivil, J. Francos, R. González-Fernández, P. J. González-Liste, J. Borge, V. Cadierno, Dalton Trans. 45 (2016) 13590-13603.

[89] R. J. Newland, M. P. Delve, R. L. Wingad, S. M. Mansell, New J. Chem. 42 (2018) 19625-19636.

[90] R. González-Fernández, P. Crochet, V. Cadierno, M. I. Menéndez, R. López, Chem. Eur. J. 23 (2017) 15210-15221.

[91] R. González-Fernández, P. Crochet, V. Cadierno, ChemistrySelect 3 (2018) 4324-4329.

[92] M. Caporali, M. Di Vaira, M. Peruzzini, S. S. Costantini, P. Stoppioni, F. Zanobini, Eur. J. Inorg. Chem. (2010) 152-158.

[93] M. A. Esteruelas, A. M. López, J. I. Tolosa, N. Vela, Organometallics 19 (2000), $4650-4652$.

[94] M. A. Esteruelas, A. Lledós, M. Martín, F. Maseras, R. Osés, N. Ruiz, J. Tomàs, Organometallics 20 (2001) 5297-5309.

[95] J. Xie, J.-S. Huang, N. Zhu, Z.-Y. Zhou, C.-M. Che, Chem. Eur. J. 11 (2005) 2405-2416. 
[96] D. Carmona, C. Vega, N. García, F. J. Lahoz, S. Elipe, L. A. Oro, M. P. Lamata, F. Viguri, R. Borao, Organometallics 25 (2006) 1592-1606.

[97] U. Schubert, R. Werner, L. Zinner, H. Werner, J. Organomet. Chem. 253 (1983) 363-374.

[98] T. Ghaffar, A. W. Parkins, Tetrahedron Lett. 36 (1995) 8657-8660.

[99] For a review on the synthetic applications of complex 143, see: V. Cadierno, Appl. Sci. 5 (2015) 380-401.

[100] For a recent review article on the specific contribution of ruthenium to metalcatalyzed $\mathrm{C} \equiv \mathrm{N}$ bond hydration reactions, see: R. García-Álvarez, J. Francos, E. Tomás-Mendivil, P. Crochet, V. Cadierno, J. Organomet. Chem. 771 (2014) 93104.

[101] (a) S. M. M. Knapp, T. J. Sherbow, J. J. Juliette, D. R. Tyler, Organometallics 31 (2012) 2941-2944; (b) S. M. M. Knapp, T. J. Sherbow, R. B. Yelle, L. N. Zakharov, J. J. Juliette, D. R. Tyler, Organometallics 32 (2013) 824-834.

[102] For recent a recent review article on the catalytic rearrangement of aldoximes, see: P. Crochet, V. Cadierno, Chem. Commun. 51 (2015) 2495-2505.

[103] For selected reviews on the metal-catalyzed TH of carbonyl compounds in aqueous phase, see: (a) X. Wu, J. Xiao, Chem. Commun. (2007) 2449-2466; (b) X. Wu, C. Wang, J. Xiao, Platinum Met. Rev. 54 (2010) 3-19; (c) Y.-M. He, Q.H. Fan, ChemCatChem 7 (2015) 398-400.

[104] R. González-Fernández, P. Crochet, V. Cadierno, Org. Lett. 18 (2016) 61646167.

[105] E. Liardo, R. González-Fernández, N. Ríos-Lombardía, F. Morís, J. GarcíaÁlvarez, V. Cadierno, P. Crochet, F. Rebolledo, J. González-Sabín, ChemCatChem 10 (2018) 4676-4682. 
[106] M. L. Buil, V. Cadierno, M. A. Esteruelas, J. Gimeno, J. Herrero, S. Izquiedo, E. Oñate, Organometallics 31 (2012) 6861-6867 and references cited therein.

[107] See, for example: (a) J. J. Li (Ed.), C-H Bond Activation in Organic Synthesis, CRC Press, Boca Ratón, 2015; (b) J.-Q. Yu, Z. Shi (Eds.), C-H Activation, Springer, Berlin, 2010.

[108] For selected review articles in the field, see: (a) L. Ackermann, Chem. Rev. 111 (2011) 1315-1345; (b) P. B. Arockiam, C. Bruneau, P. H. Dixneuf, Chem. Rev. 112 (2012) 5879-5918; (c) L. Ackermann, Org. Process Res. Dev. 19 (2015) 260-269.

[109] This topic has been reviewed: (a) L. Ackermann, Synlett (2007) 507-526; (b) L. Ackermann, Isr. J. Chem. 50 (2010) 652-663.

[110] L. Ackermann, Org. Lett. 7 (2005) 3123-3125.

[111] L. Ackermann, R. Vicente, A. Althammer, Org. Lett. 10 (2008) 2299-2302.

[112] L. Ackermann, E. Diers, A. Manvar, Org. Lett. 14 (2012) 1154-1157.

[113] L. Ackermann, A. Althammer, R. Born, Angew. Chem. Int. Ed. 45 (2006) 26192622.

[114] L. Ackermann, M. Mulzer, Org. Lett. 10 (2008) 5043-5045.

[115] L. Ackermann, Pure Appl. Chem. 82 (2010) 1403-1413.

[116] H. Landert, F. Spindler, A. Wyss, H.-U. Blaser, B. Pugin, Y. Ribourduoille, B. Gschwend, B. Ramalingam, A. Pfaltz, Angew. Chem. Int. Ed. 49 (2010) 68736876.

[117] X. Tan, W. Zeng, X. Zhang, L. W. Chung, X. Zhang, Chem. Commun. 54 (2018) 535-538. 
[118] See, for example: F. S. S. Schneider, M. Segala, G. F. Caramori, E. H. da Silva, R. L. T. Parreira, H. S. Schrekker, P. W. N. M. van Leeuwen, J. Phys. Chem. C 122 (2018) 21449-21461 and references cited therein.

[119] E. Rafter, T. Gutmann, F. Löw, G. Buntkowsky, K. Philippot, B. Chaudret, P. W. N. M. van Leeuwen, Catal. Sci. Technol. 3 (2013) 595-599.

[120] B. Lastra-Barreira, J. Francos, P. Crochet, V. Cadierno, Organometallics 37 (2018) 3465-3474.

[121] I. R. Cabrita, P. R. Florindo, P. J. Costa, M. C. Oliveira, A. C. Fernandes, Mol. Catal. 450 (2018) 77-86. 